عمارة المكان

صيخ التعامل مع السياق المكاني في العمارة العراقية المعاصرة ( • 9 ( ـ • 9 9 ( )

شذى بعقوب الثيخ

نعم بهنام منونة

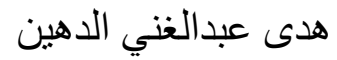

مدرس مساعد

مدرس مساعد

مدرس مساعد ملاعر مل

قسم الهندسة المعمارية/جامعة الموصل

\title{
الخلاصة
}

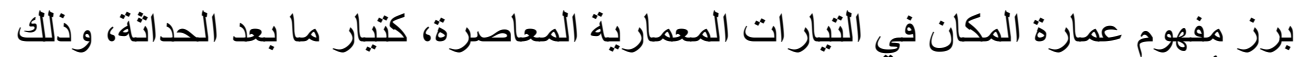

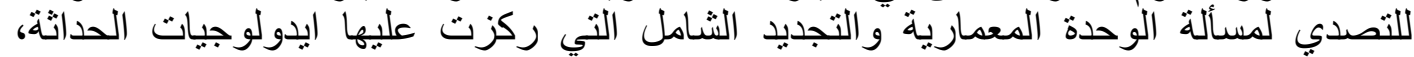

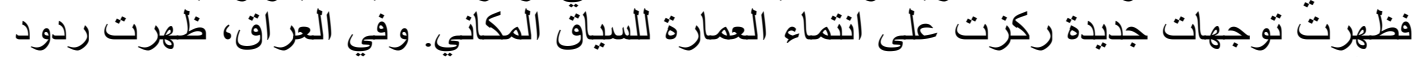

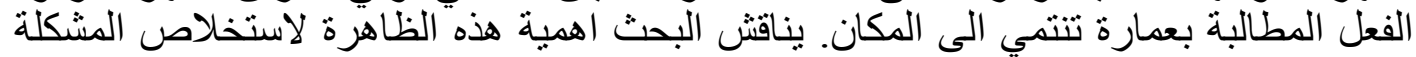

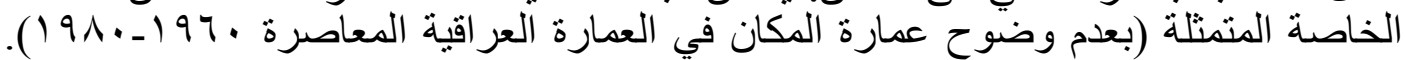

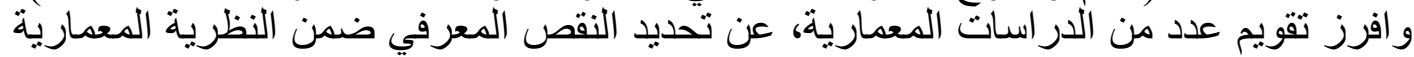

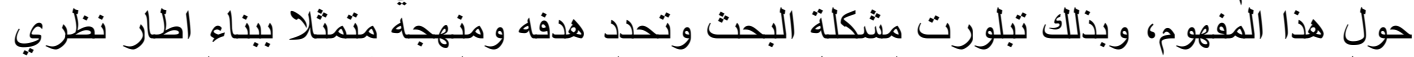

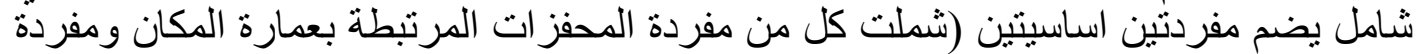

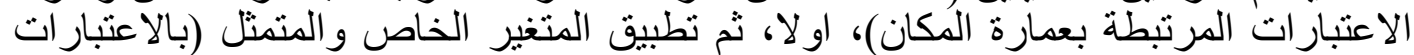

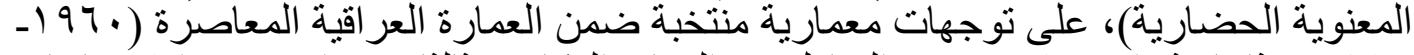

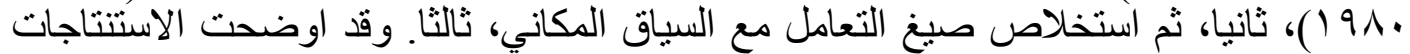

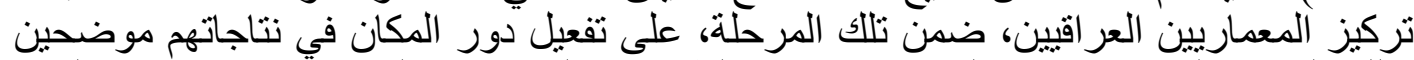

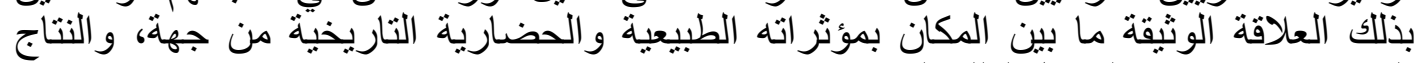

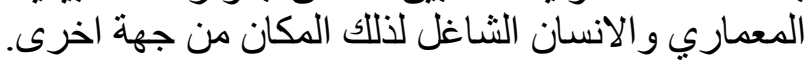

\section{Paradigms of Dealing with Context of Place in Iraqi Contemporary Architecture (1960-1980)}

\author{
Huda A. Al-Daheen Niem B. Manouna Shatha Y. El-Sheikh \\ Ass. Lecturer \\ Ass. Lecturer \\ Ass. Lecturer
}

Arch. Dep. / Mosul University

\section{Abstract}


الثيخ :عمارة المكان -صيخ التعامل مع السياق المكاني في العمارة العر اقية المعاصرة (•97 (19191)

Architecture of place is a preposition presented in the modern architectural trends, especially in post-modernisim as a reaction against modern architecture and its planning ideology of architectural unity. New trends were emerged concentrating on architecture related to place. As in Iraq. The paper discusses the importance of this subject, in order to explore the particular problem which has been represented as (lack of clarity of architecture of place in Iraqi contemporary architecture 19601980).

Thus the objectives of the paper has been formed and method has been specified by building theoretical framework consisting of two main items as the following: (Responses and considerations relating to architecture of place), firstly, then the application of the cultural considerations on selected architectural trends through Iraqi contemporary architecture (1960-1980), secondly, finally, concluding paradigms of dealing with context of place, thirdly.

Coclusions have been declared the importance of the role of place in works of Iraqi architects during sixties and seventies concentrating on the strong relationship between the place with its natural and cultural considerations, on one hand, and the product (building) and the human being who inhabits it, on the other hand.

Keywords: Architecture of place, Iraqi contemporary architects, Context of place.

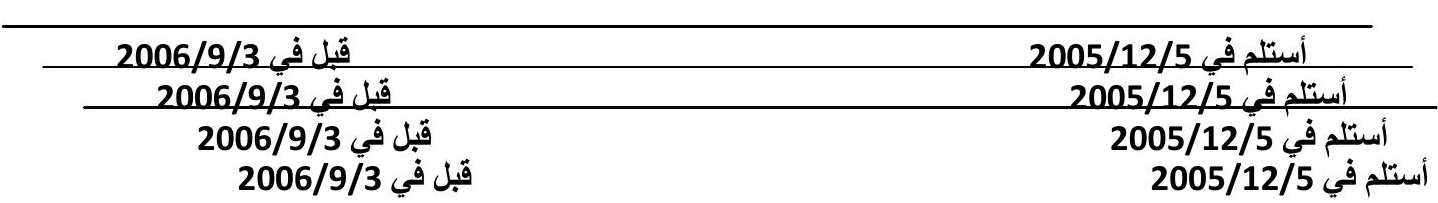




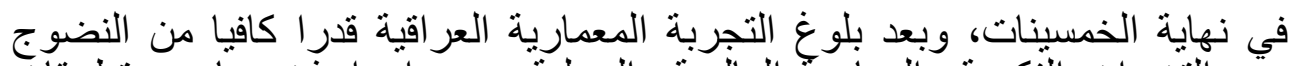

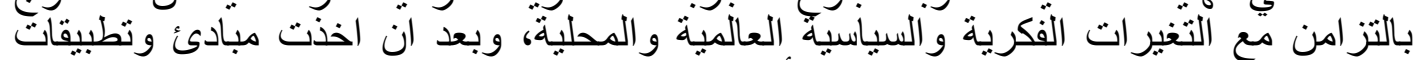

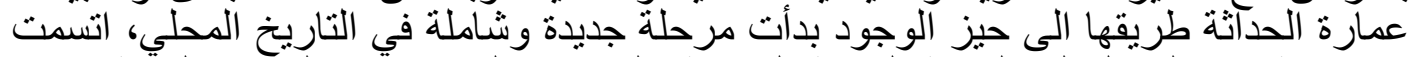

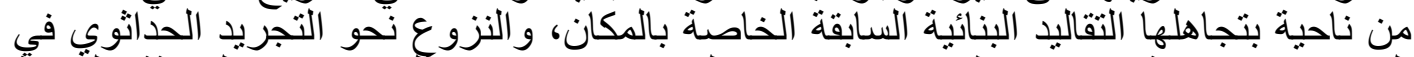

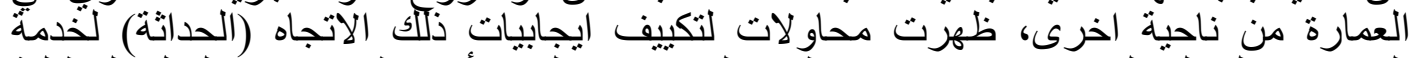

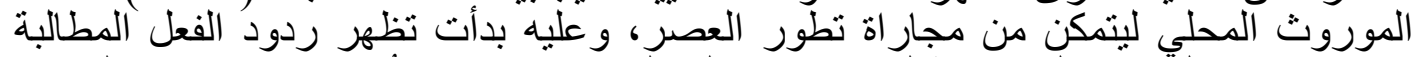

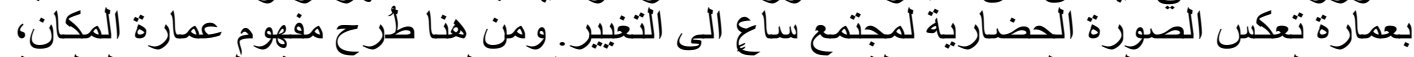

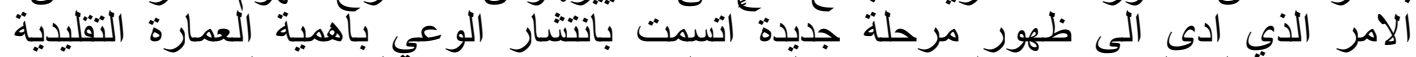

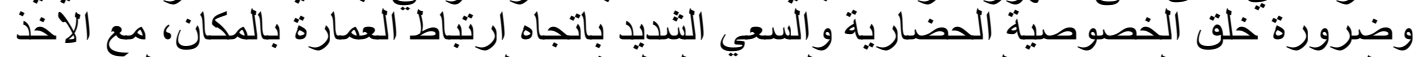

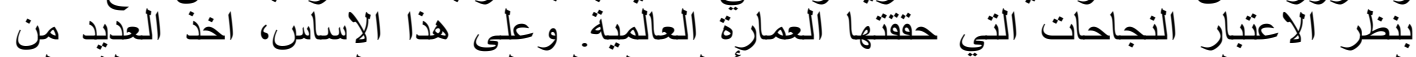

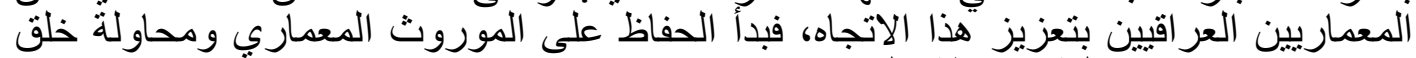
عمارة ذات ملامح محلية مرتبطة بالمكان ومعبرة عنهاه.

2- عمارة المكان - اهمية الموضوع

في عقدي الستينات و السبعينات، كان بالامكان تحسس اهمية وتفرد الحلول التكوينية الفنية،

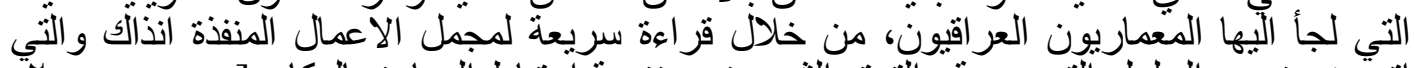

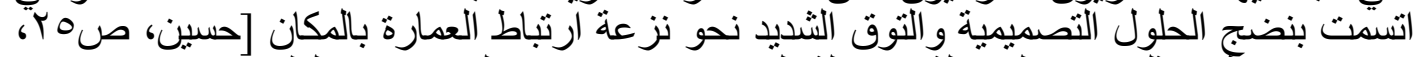

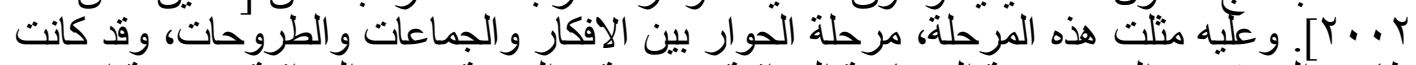

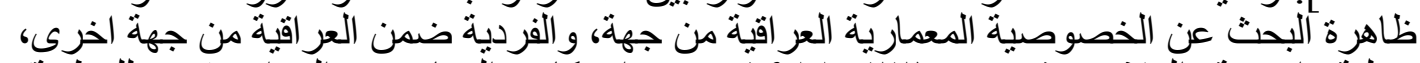

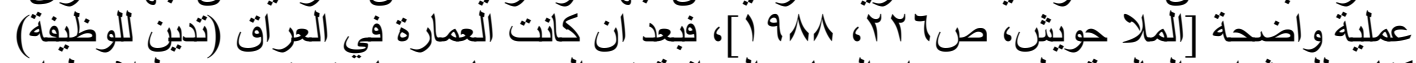

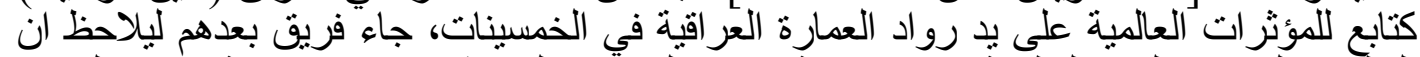

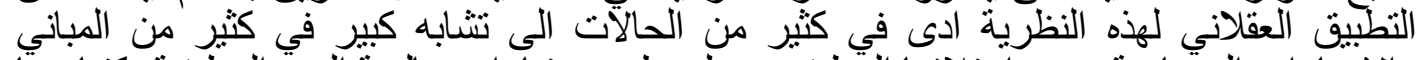

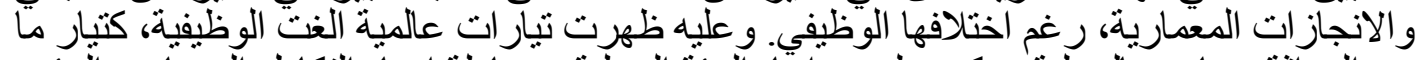

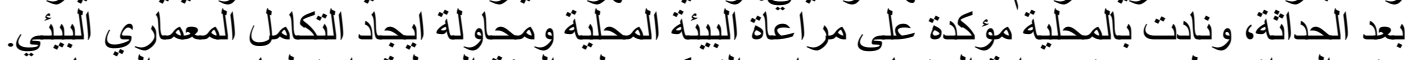

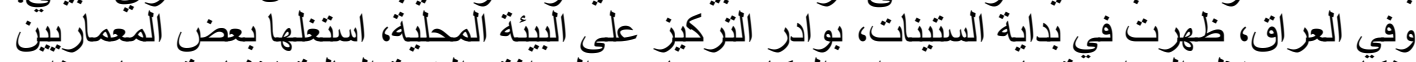

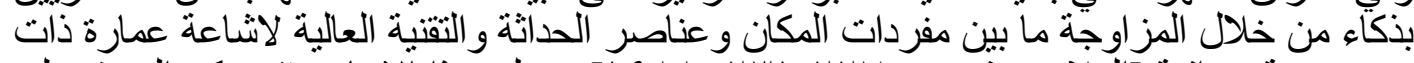

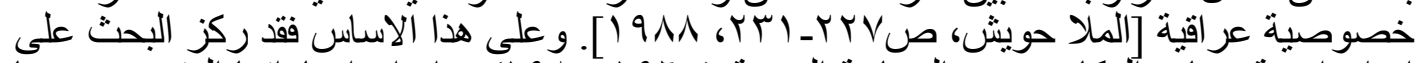

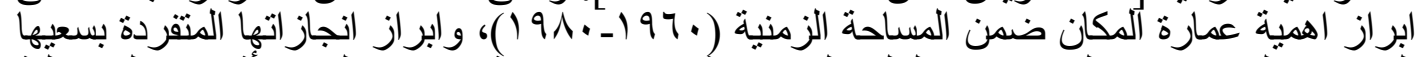

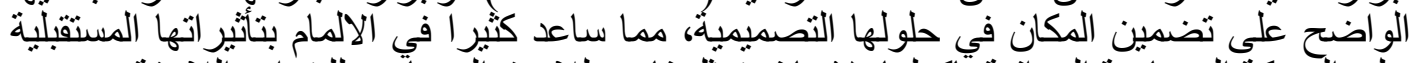

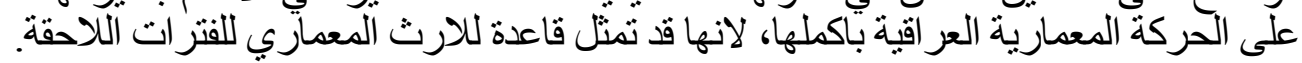

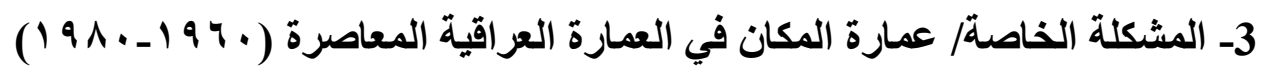
برزت في الو اقع المعماري العديد من المشكلات المرتبطة بعمارة المكان، تعلقت احداها لهاهيا

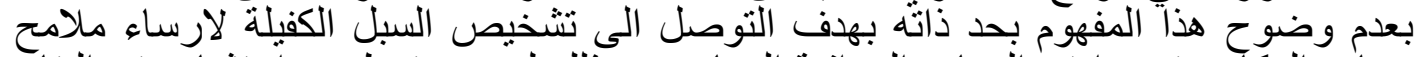

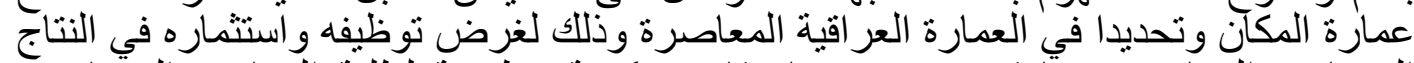

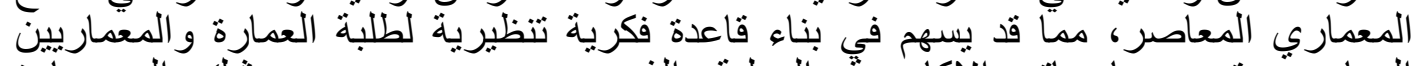

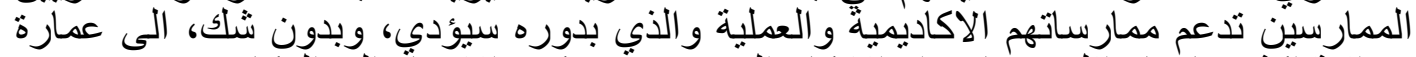
عر اقية اكثر تناسقاو اقل جريا ور اء الافكار المستوردة، تعكس الانتماء الى المكان. 
و عند تفحص دقيق لو اقع المعرفة النظرية في الدراسات المعمارية، وجد ان هنالك تناقض في الإني

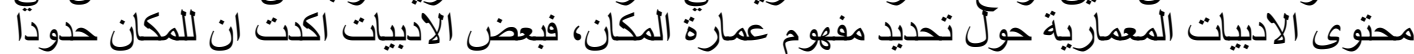

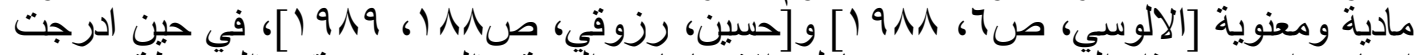

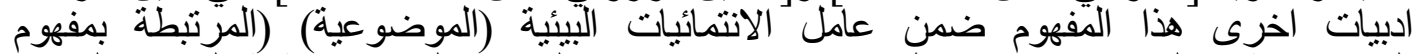

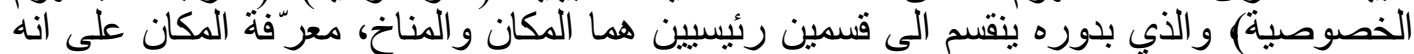

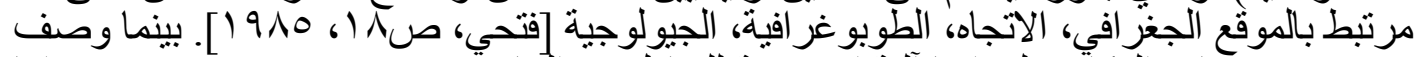
[Jencks]

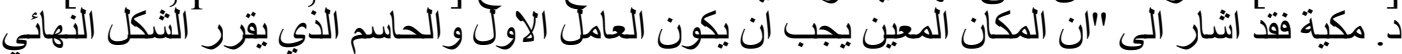

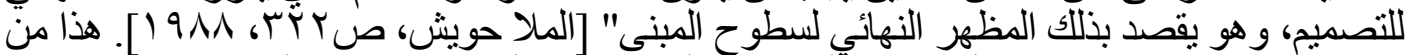

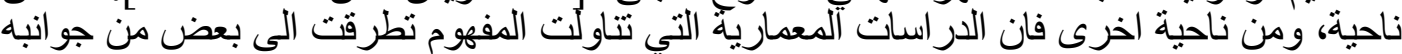

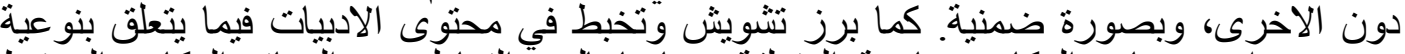

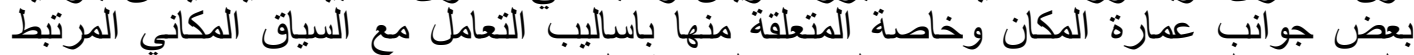

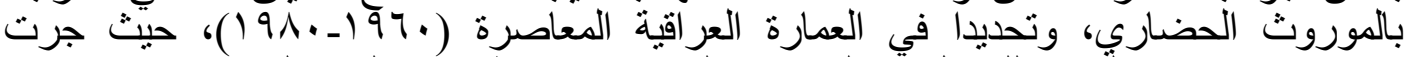

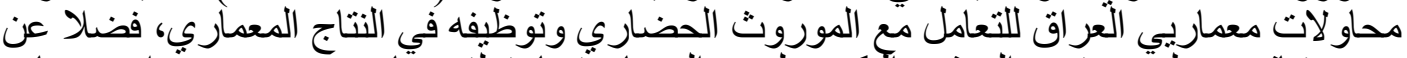

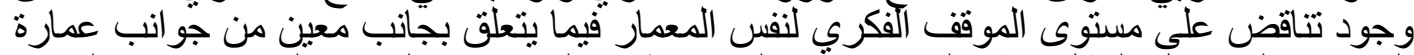

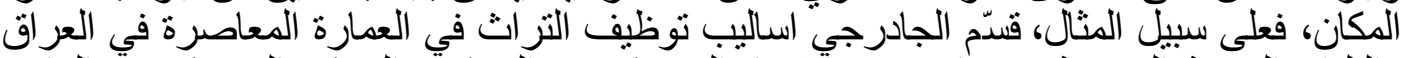

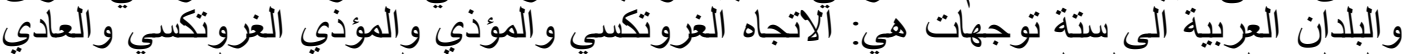

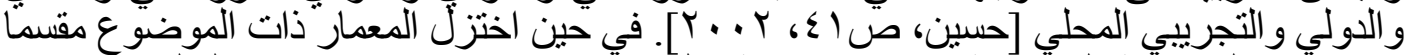

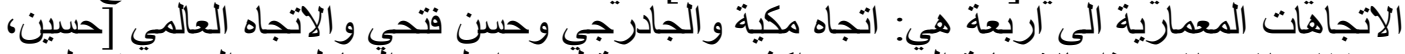

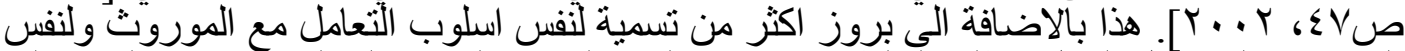

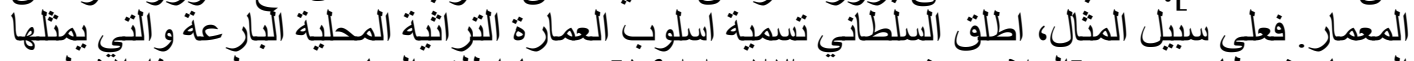

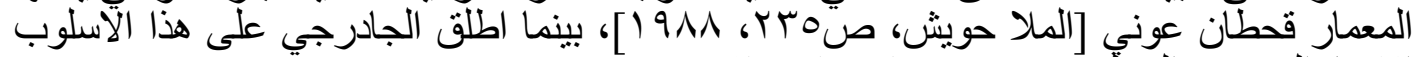

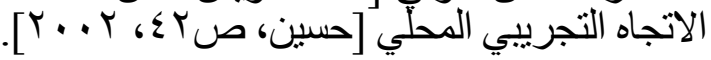

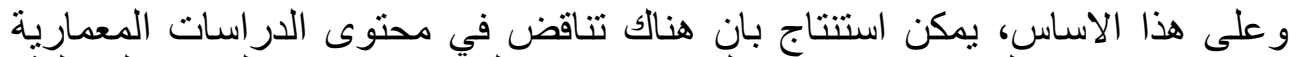

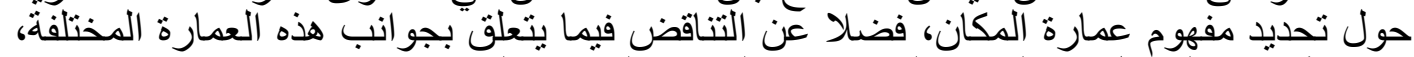

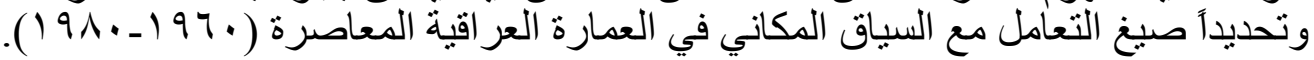

4- المشكلة البحثية/ عمارة المكان/ المعرفة العلمية السابقة بالموضوع

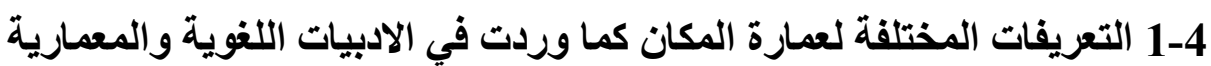

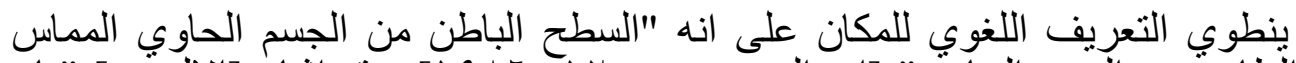

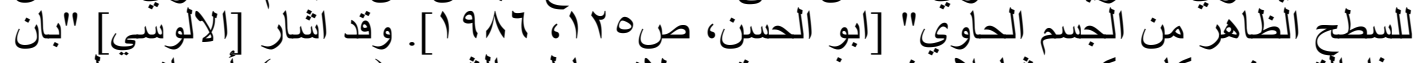

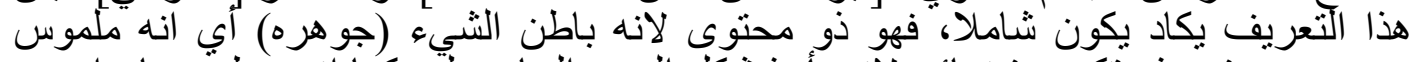

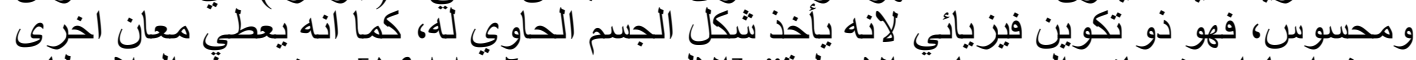

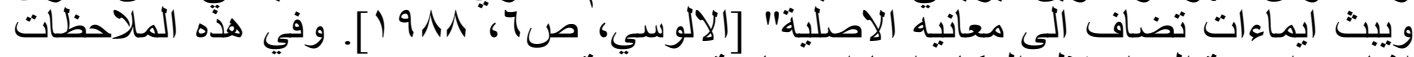

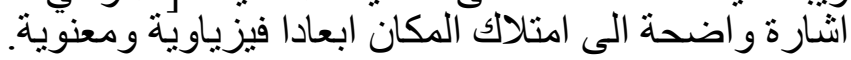

ومن التعريفات الاخرى للمكان في الادبيات المعمارية، كونه يمنل المحتوى الانتمائي

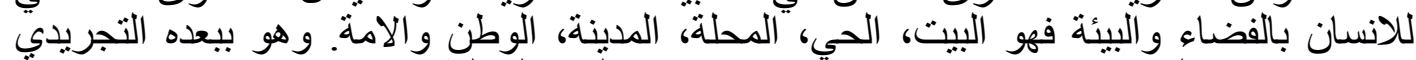

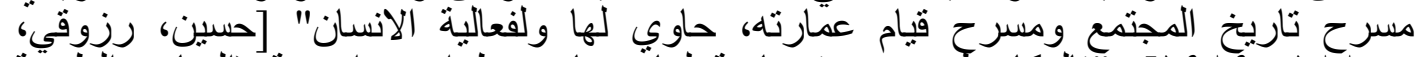

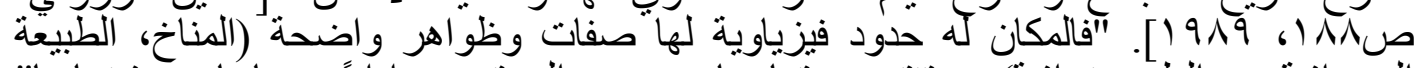

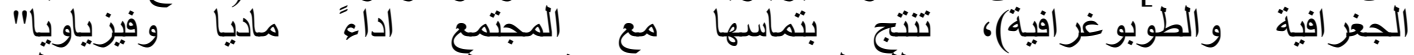
[1981, p. 7, Casey] 


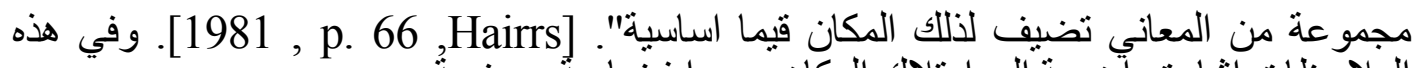
الملاحظات اثنارة واضحة الى امتلاك المكان حدودا فيزياوية ومعنوية.

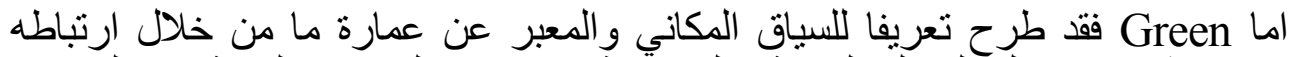

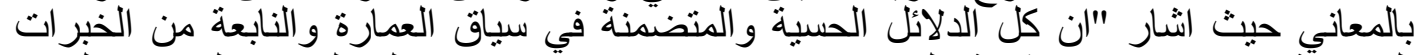

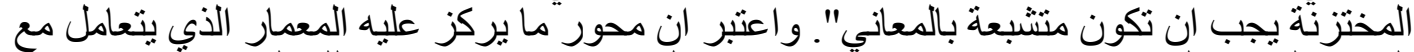

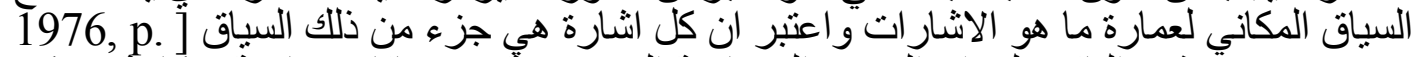
7, Green

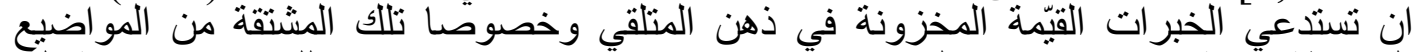

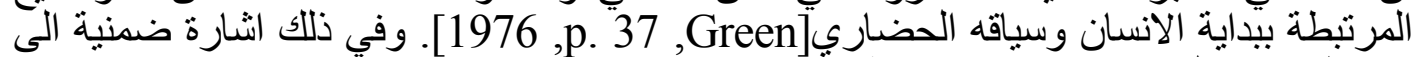
ارتباط عمارة المكان باعتبار ألت معنوية.

كما اورد [ثويني] مفهوم المعمار د. مكية عن المكان من خلان لإن "اعتبار العمارة مفهوم

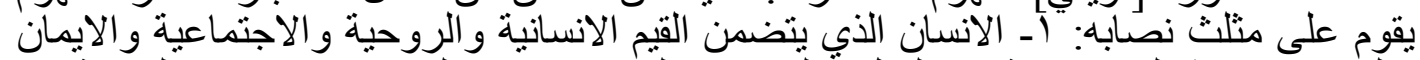

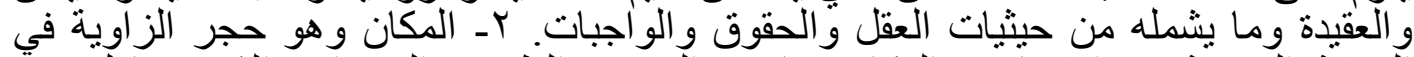

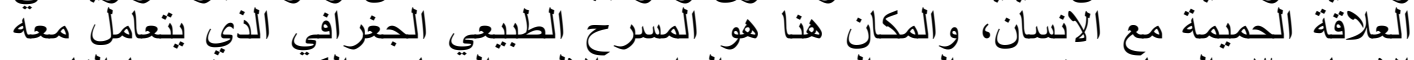

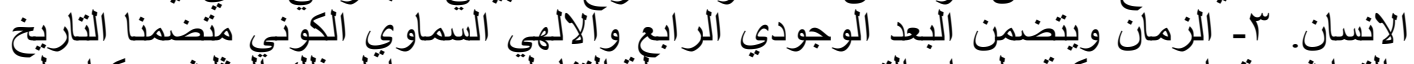

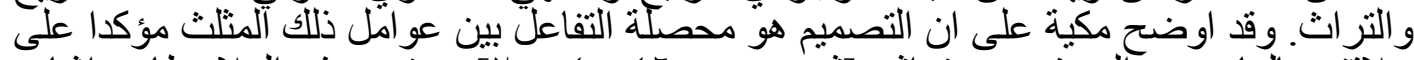

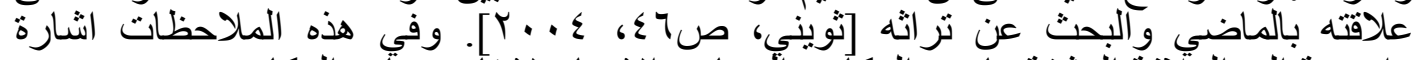

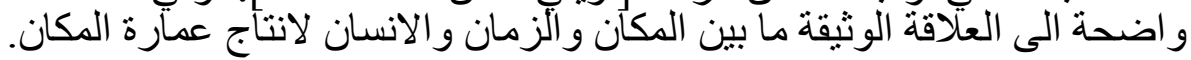

نستتنج من ذلك بان عمارة المكان تمثل النتاج او التكوين البصري الحاوي للانسان

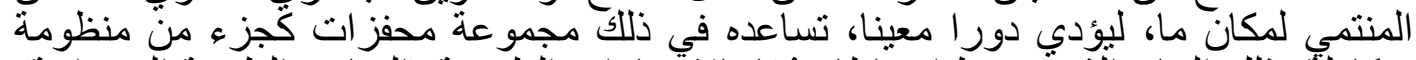

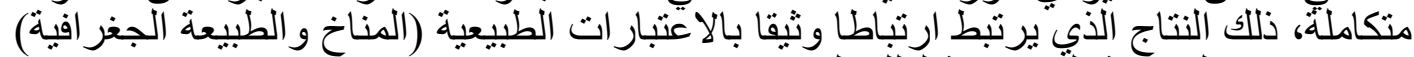

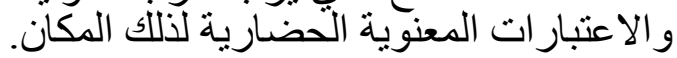

2-4 - 2-4 الدارات السابقة

قام البحث بتقويم واقع المعرفة النظرية المتعلقة بعمارة المكان في عدد من الادبيات و الدر اسات المعمارية والتي شملت:

أ- دراسات عالمية عامة

\section{6 /(Mind and Image) Green 1-2-4 دراسة درة}

تعد دراسة Green من الدراسات ذات الطابع الوصفي. ابرزت الارتباط التباط بين التوجه

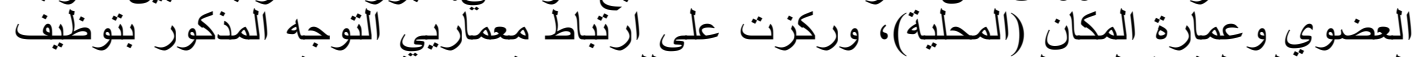

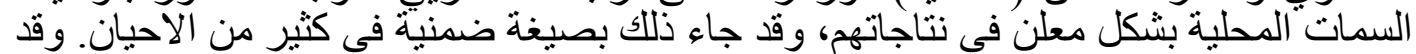

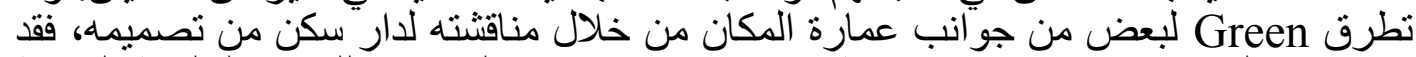

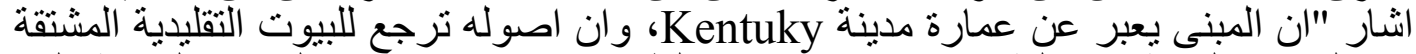

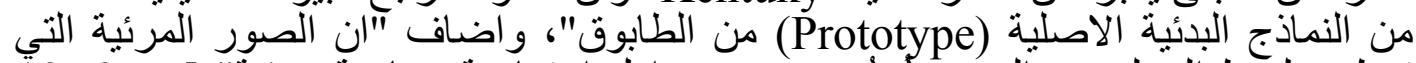

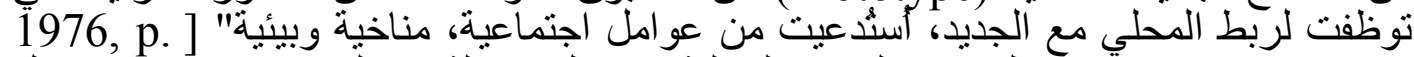
[98, Green

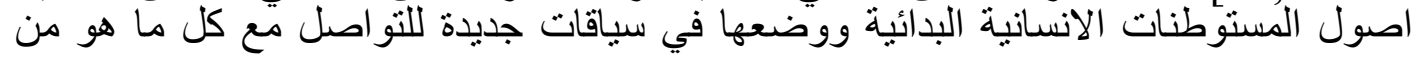


تاريخ الانسان" [1976, p. 98, Green]. ان الملاحظات الوصفية تضمنت اشار ات ضمنية

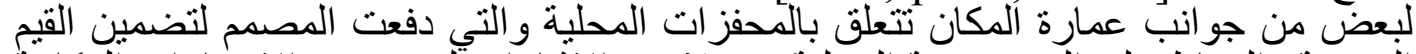

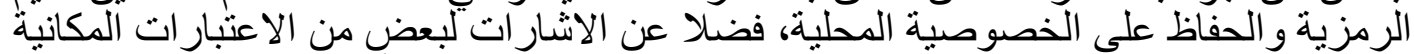
المادية كالمناخ و الطبيعة الديموغر افية للانسان، و المعنوية كالمر اجع و آلية التعامل معها.

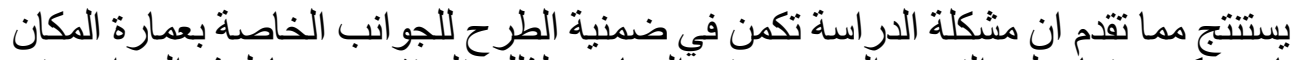

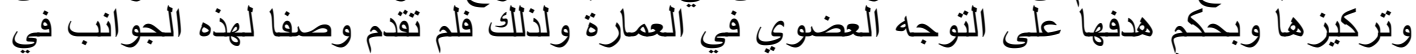

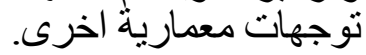

\section{8 /(Architecture Today) Jencks 2-2-4 دراسة}

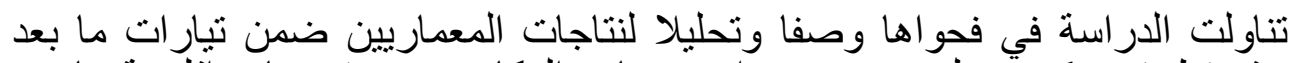

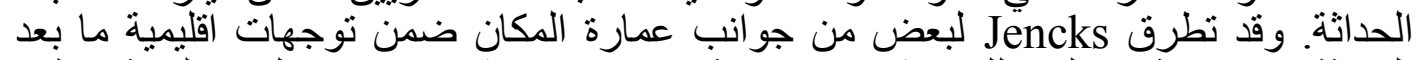

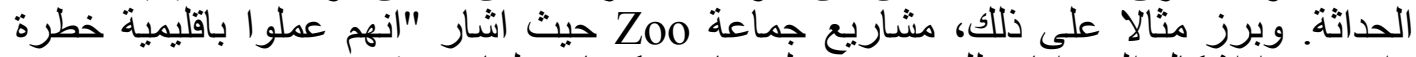
و واستخذموا انثكال الحيو انات للتموضع حول مبانيهم كمفاتيح لها" [1988, p. 320, Jencks].

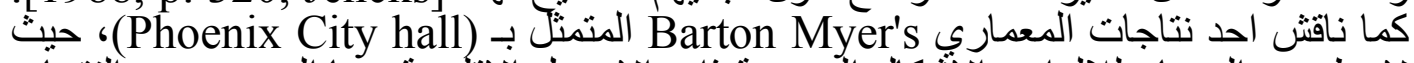

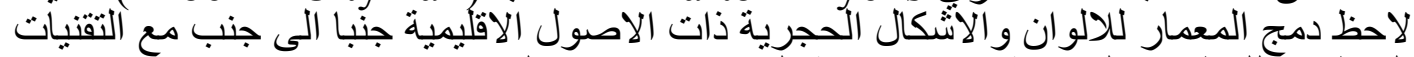

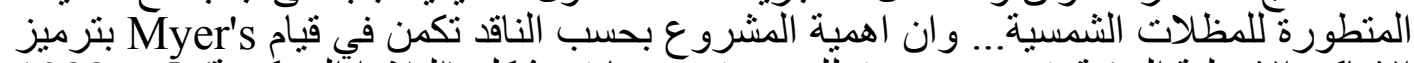

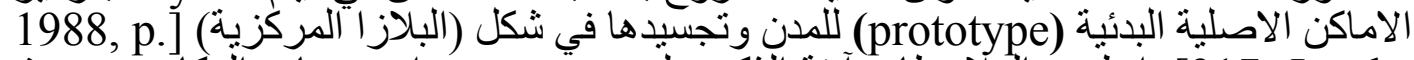
317, Jencks

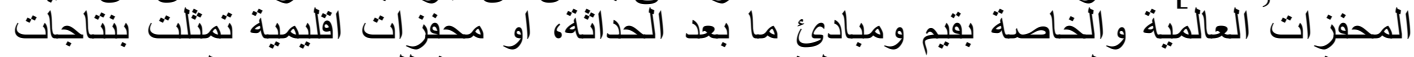

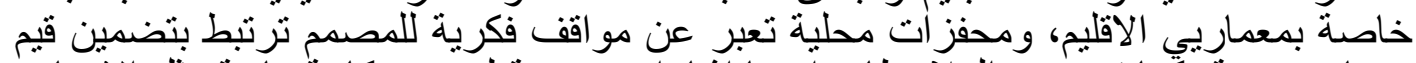

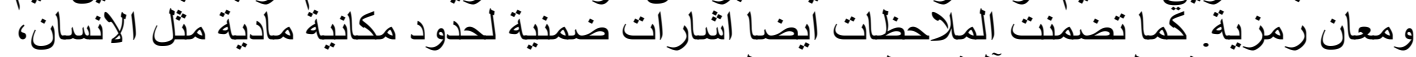
او حدود معنوية كالمر اجع وآلية توظيفها في النتاج.

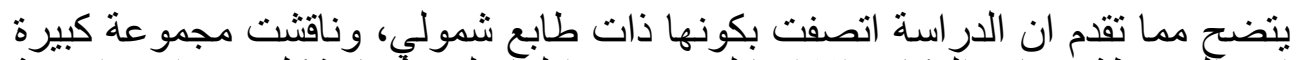

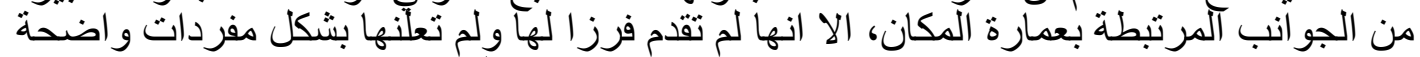

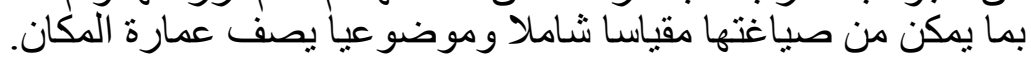

بـ دراسات محلية متخصصة

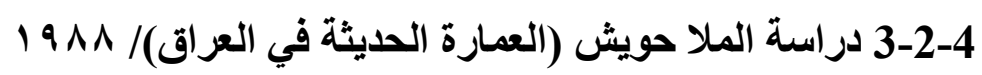

تعد دراسة الملا حويش واحدة من الدراسات المتخصصة في موضو ع عمارة المكان،

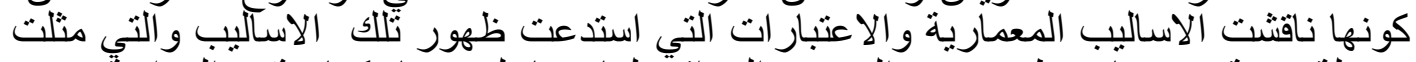

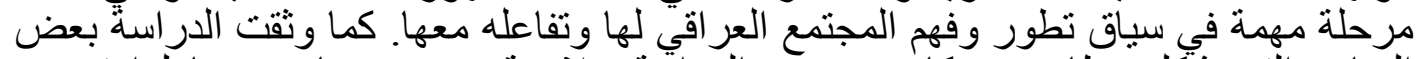

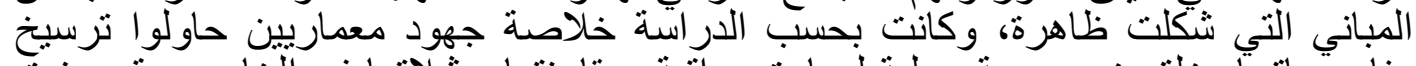

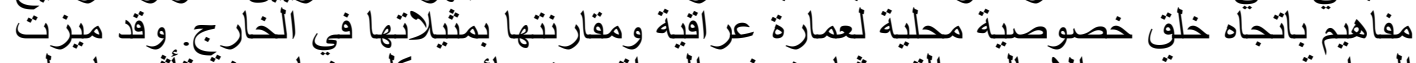

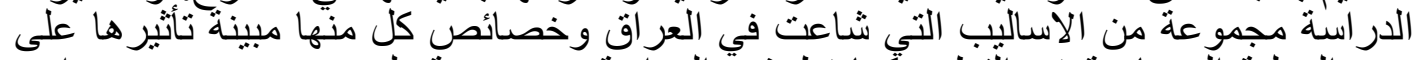

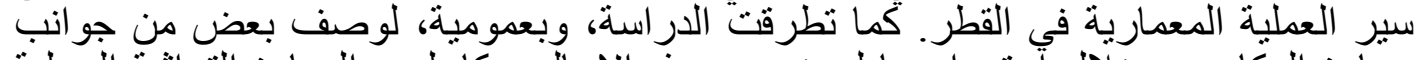

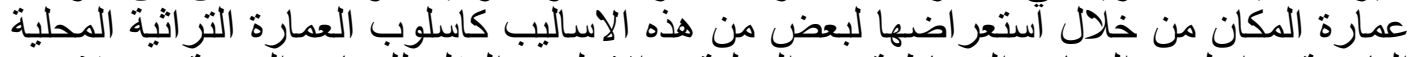

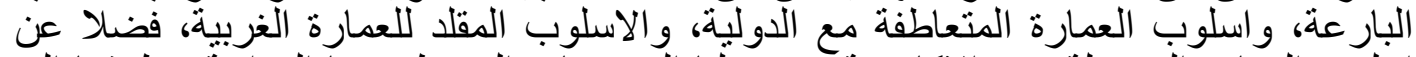

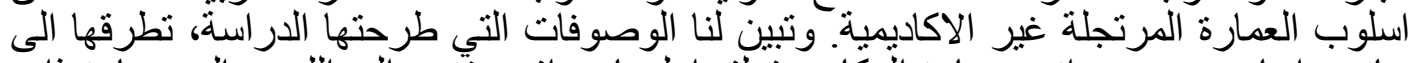

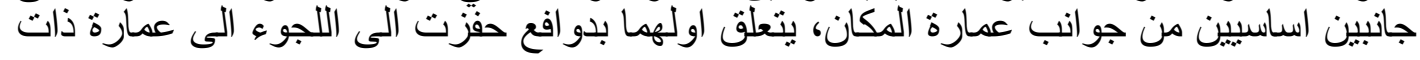




\begin{tabular}{llll} 
Al-Rafidain Engineering & Vol.15 & No.4 & 2007 \\
\hline
\end{tabular}

خصوصية محلية، سواء على المستوى النظري كطروحات او على المستوى العملي كنتاجات

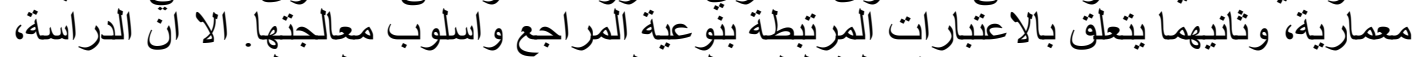
وبحكم هدفها الاستقر ائي، اتسمت بشمولية الطرح لهذه الجو النب، فضلا عن التداخل فئل فيما بينها.

\section{4-2-4 دراسة الجادرجي (الاخيضر والقصر البلوري)/ | 99 |}

تخصصت الدر اسة بتدوين المو اقف الفكرية للجادرجي في الحقبة الزمنية التي صمم فيها

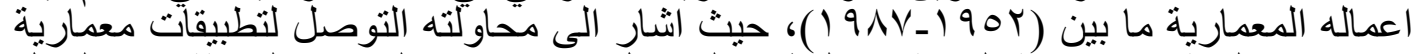

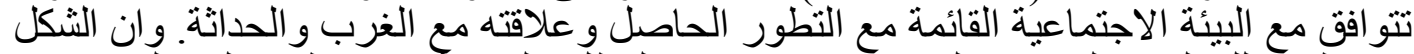

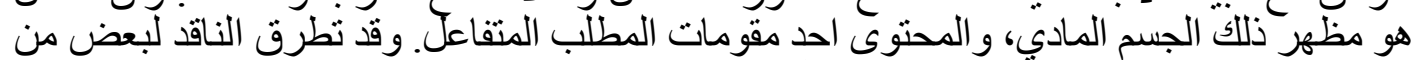

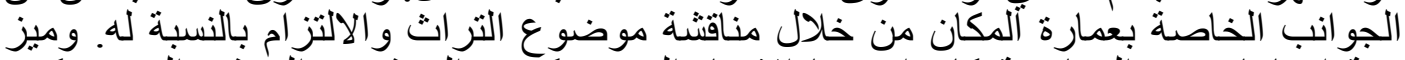

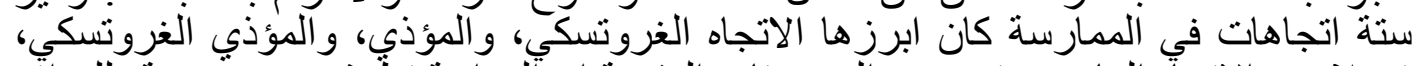

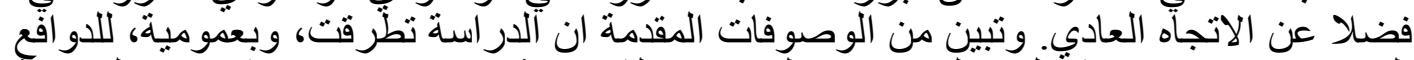

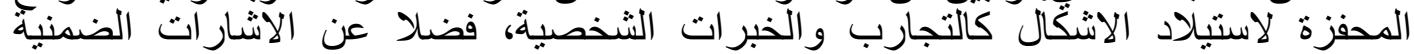

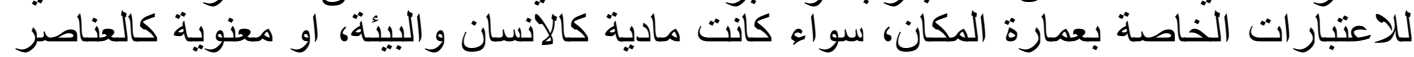

$$
\text { الخاصنة بالموروات الخاصة المحلي. }
$$

يتضح مما سبق ان دراسة الجادرجي قد وفرت قاعدة نظرية ملائمة لموضوان الذوع البحث

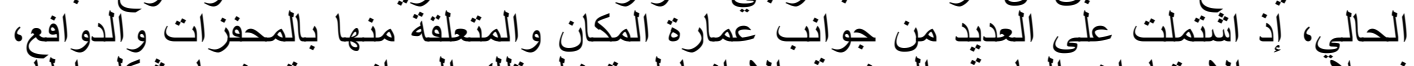

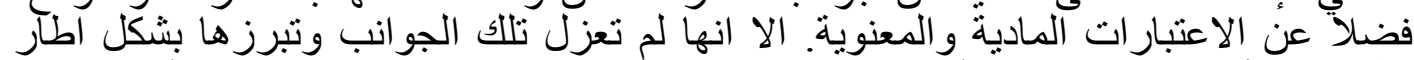

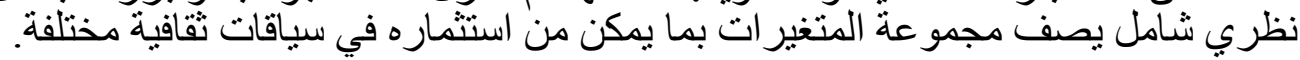

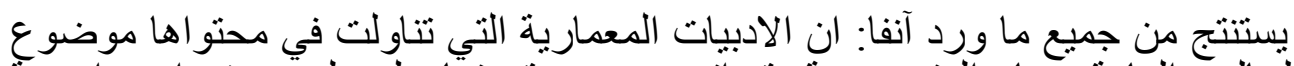

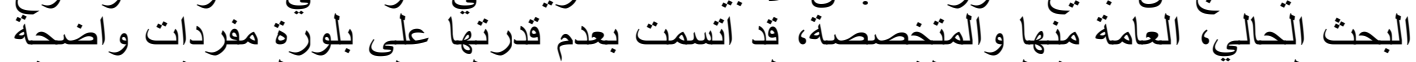

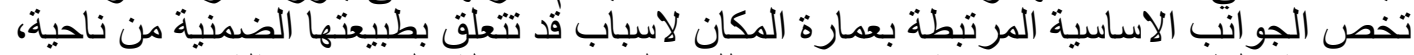

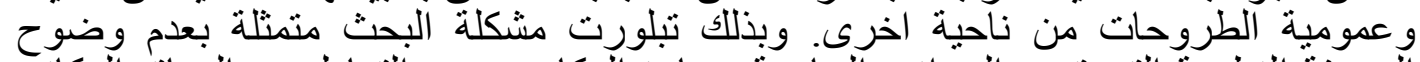

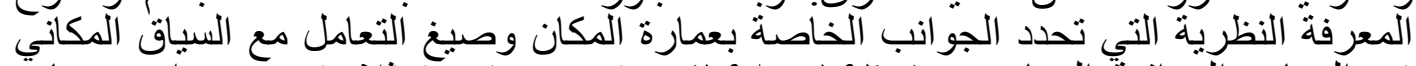

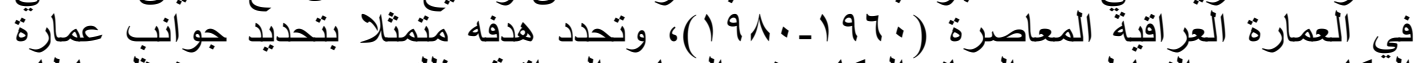

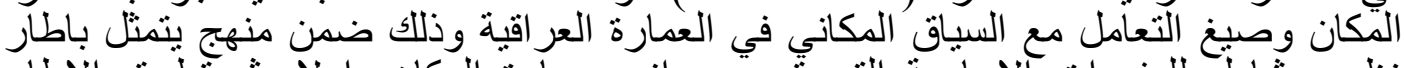

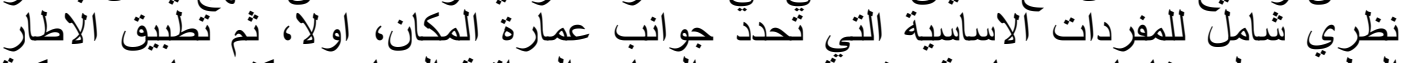

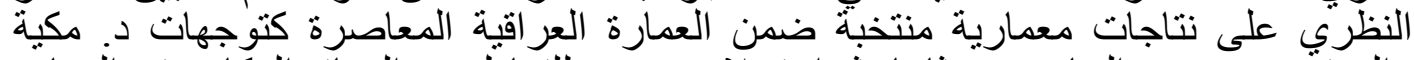

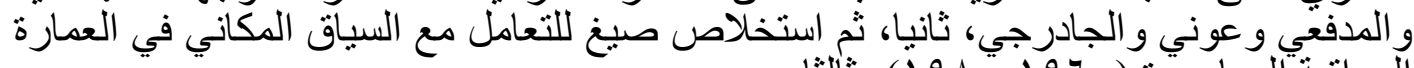

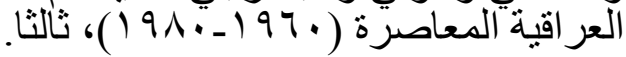

5- الاطار النظري لعمارة المكان 1-5 مفردات الاطار النظري لمفهوم عمارة المكان لقد تركز مفهوم عمارة المكان، بشكل عام، حول مفردنين اساسيتين شملت كل من: ا - المحفزات المرتبطة بعمارة المكان r ـ الاعتبار ات المرتبطة بعمارة بعمارة المكان

1-1-5 المفردة الاولى/ المحفزات المرتبطة بعمارة المكان 
تمثل المحفزات المرتبطة بعمارة الدكان، مجموعة المسببات او الدوافع التي حفزت

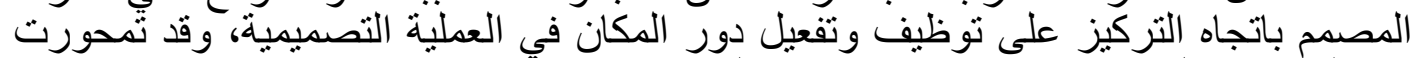

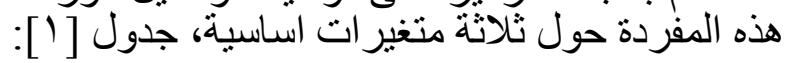

أـ المحفزات العالمية (الموضوعية)، وبدور ها تمحورت حول متغيرين ثانويين شملا كلا من محفز ات عالمية تخص العمارة واخرى لا لخص ندص العمارة.

بـ المحفزات الاقليمية، وبدور ها ايضا تمحورت حول متغيرين ثانويين شملا كلا من محفزات

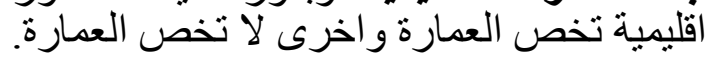

ج- المحفزات المحلية، وبدور ها تمحورت حول ثلاثثة متغير ات ثانوية هي: المحفز ات المحلية الآذاتية، الدحفز ات الدحلية الدكتسبة، فضلا عن الدحفز ات المحلية النفعية.

أـ المحفزات العالمية الموضوعية

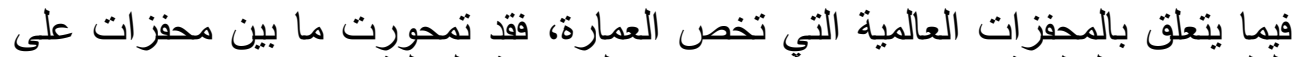

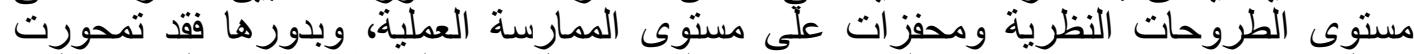

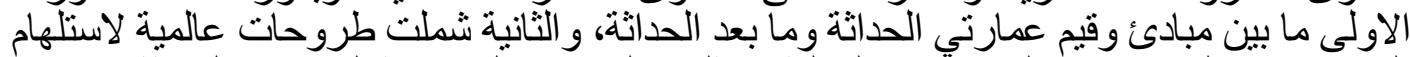

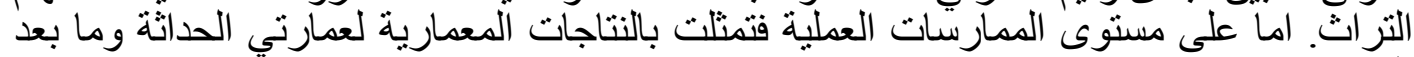

وفيما يتعلق بالمتغير الخاص بالطروحات النظرية والمتمثل بمبادئ وقيم عمارني

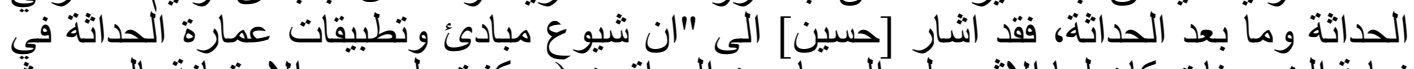

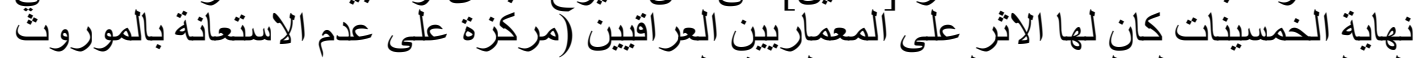

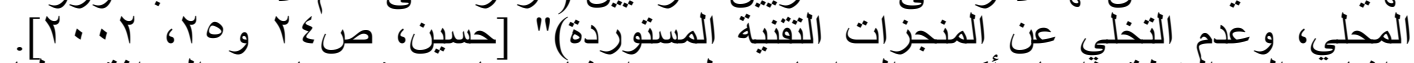

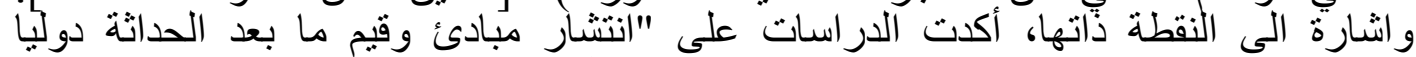

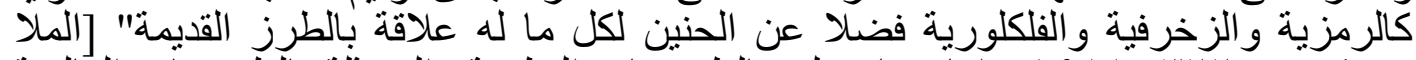

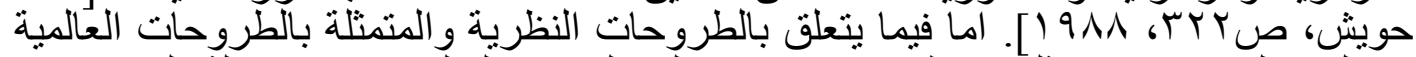

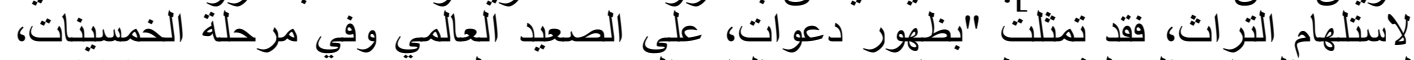

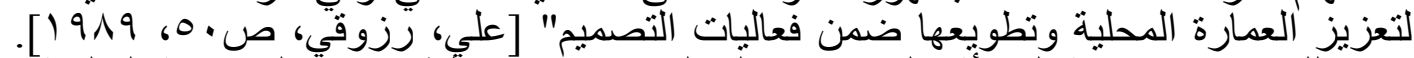

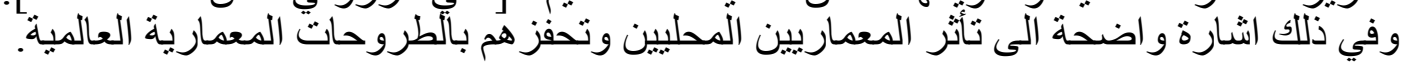

اما فيما يتعلق بالمتغير الخاص بالمحفز ات العالمية المعمارية وعلى مستوى الممارسات

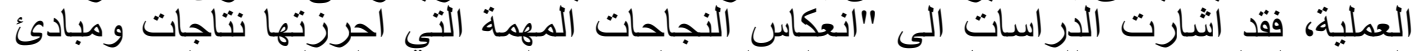

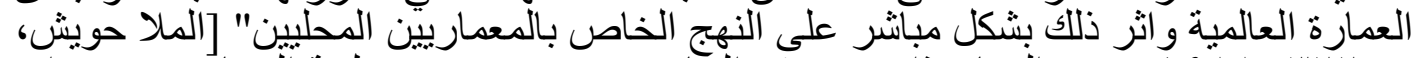

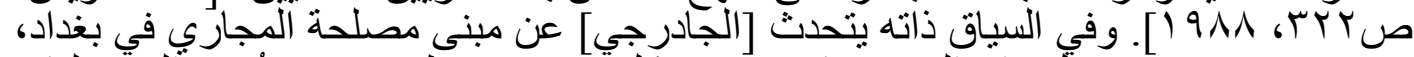

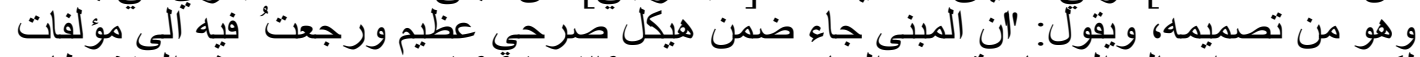

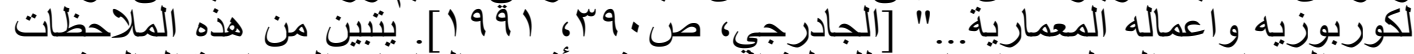

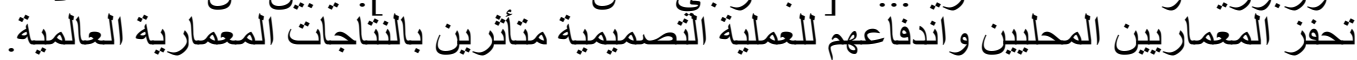




\begin{tabular}{llll} 
Al-Rafidain Engineering & Vol.15 & No.4 & 2007 \\
\hline
\end{tabular}

جدول [ [ ] المفردة الاولى/ مفردة المحفزات المرتبطة بعمارة المكان

\begin{tabular}{|c|c|c|c|c|c|}
\hline القيم الممكنة & \multicolumn{2}{|c|}{ المتغيرات الفرعية } & \multicolumn{2}{|c|}{ الاستضفيرةت } & 1 \\
\hline مبادئي وقيم عمارتي الحداتئة وما بعد & & \multirow{3}{*}{ العمارة - ل العمة } & \multirow{5}{*}{\multicolumn{2}{|c|}{ العالمينة المبو }} & \\
\hline طروحات عالمية لاستلهام التراث & & & & & \\
\hline الحذاجثة عمارتي الحداثة وما بعد & الملى مستوب العملية & & & & \\
\hline 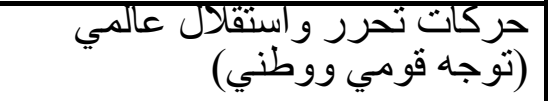 & حركات سياسية ل & \multirow{2}{*}{ العمارة: } & & & \\
\hline تبارات فكرية عالمية & توجهات فكرية & & & & \\
\hline طروحات معماريين افليميين & على & \multirow{2}{*}{ الغمارة } & \multirow{3}{*}{\multicolumn{2}{|c|}{ الالاقليميزة }} & \\
\hline نتاجات معماريين اقليميين & التطبيق العملي ألي & & & & : \\
\hline حركات التحرر القومية الاقليمية & حركات سياسية & الإنمارة & & & 讨 \\
\hline دعوة الى الخصوصياة المحلية & \multirow{4}{*}{ خاصة بالكصية } & \multirow{7}{*}{ الغمارة } & \multirow{10}{*}{\multicolumn{2}{|c|}{ 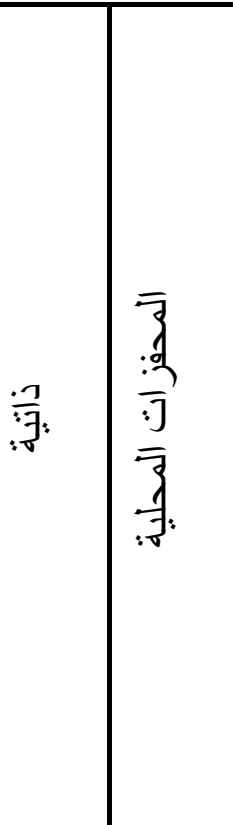 }} & 3 \\
\hline الدوروة للحفاظ على ما تبقى من & & & & & \\
\hline |تضمين القيم الرمزية & & & & & \\
\hline تضمين القيخ الجمالية & & & & & \\
\hline الفردية و عدم الثنموليه & \multirow{3}{*}{ | خواصة بالنتاجية } & & & & \\
\hline تشيو ع مبادئ التنميط & & & & & \\
\hline التقليد الجامد & & & & & \\
\hline |رسم، صنائع، خط، زخرفة & مجالات فنيه & \multirow{3}{*}{ الا لغارة } & & & \\
\hline علوم انسانية، علوم صرفة & مجالات علمية & & & & \\
\hline & & & & & \\
\hline
\end{tabular}




\begin{tabular}{|c|c|c|c|c|}
\hline مؤسسات هندسية معمارية & مينبة & \multirow[b]{3}{*}{ العمارة } & \multirow{5}{*}{ 寻 } & \\
\hline نخب معمارية محلية واجنبية & اكاديمية & & & \\
\hline 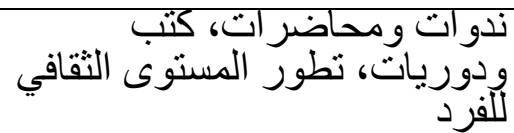 & ثقافية & & & \\
\hline قو أنين وتشَربعات محلية & تشنريعية & \multirow{2}{*}{ لالعمارة تخص } & & \\
\hline الموارد المالية & أتصادية & & & \\
\hline وظائف جديدة و متعددة & \multicolumn{2}{|c|}{ على مستوى المبنى } & \multirow{2}{*}{ : } & \\
\hline نشاط تخطيطي و اعمار المدن & \multicolumn{2}{|c|}{ على مستوى المدينة } & & \\
\hline & & & & اخرى \\
\hline
\end{tabular}

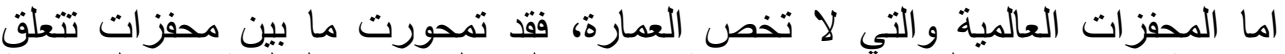

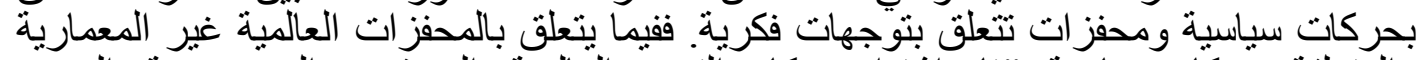

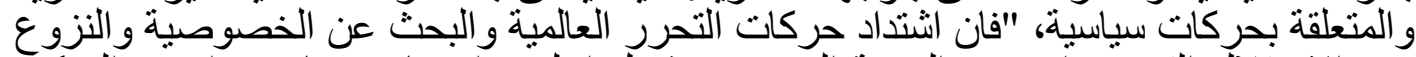

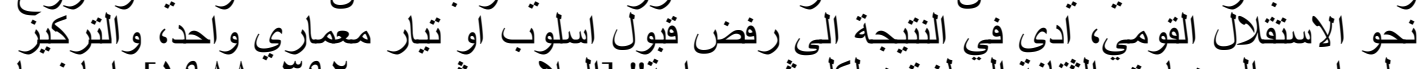

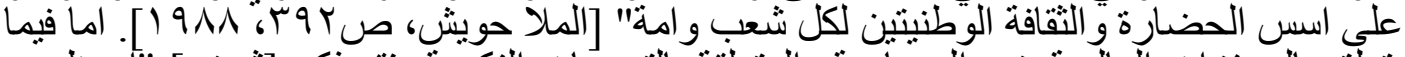

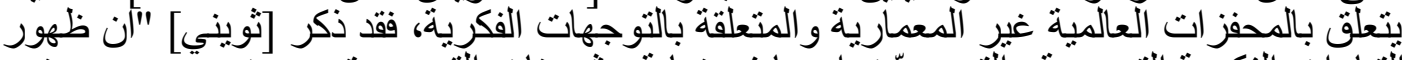

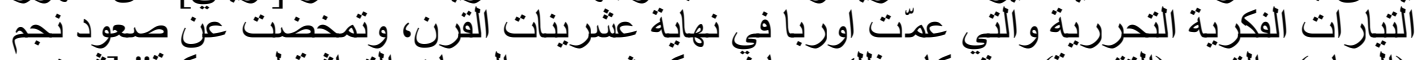

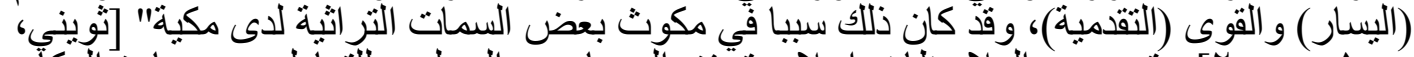

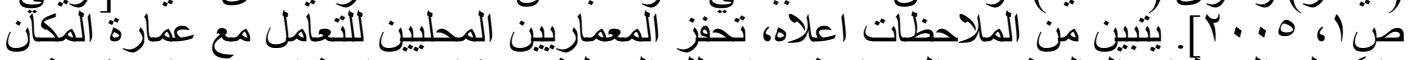
بناءٍ على المعطيات العالمية غير المعمارية سواء تللك المتعلقة بحركات سياسية او بتوجهات فكرية.

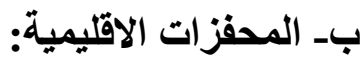

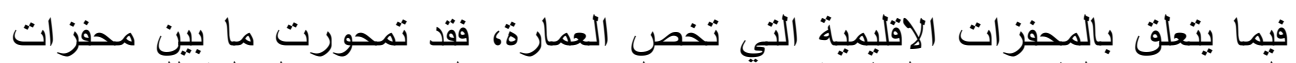

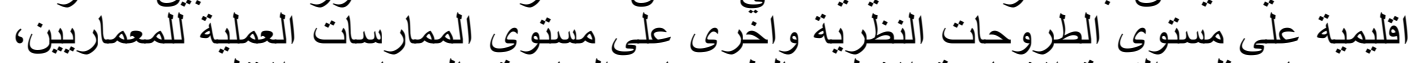

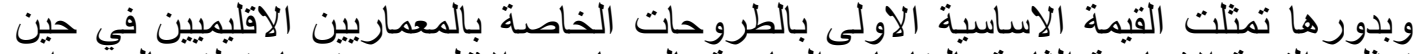

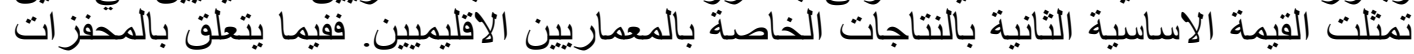

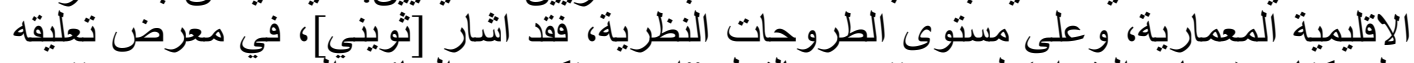

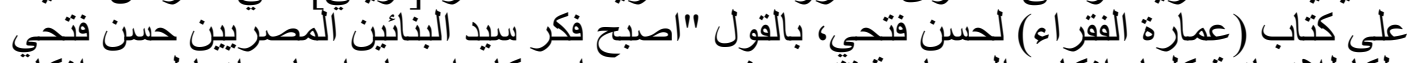

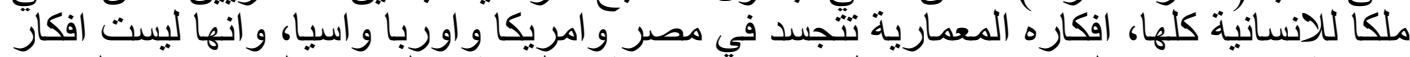

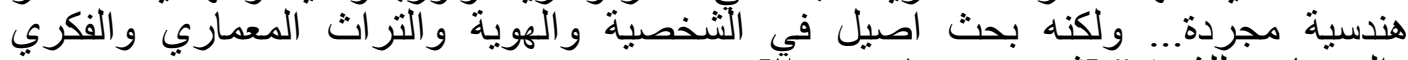

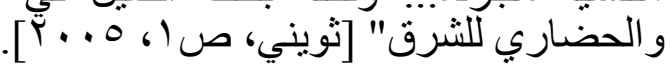

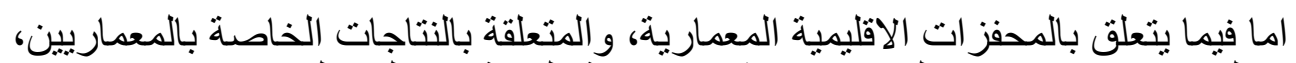

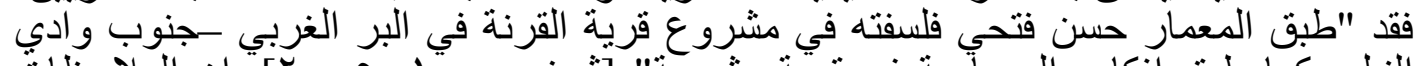

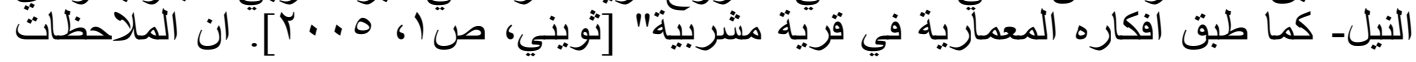


اعلاه تشير الى مدى تأثير كل من الطروحات الفكرية الاقليمية والنتاجات المعمارية المتمخضة

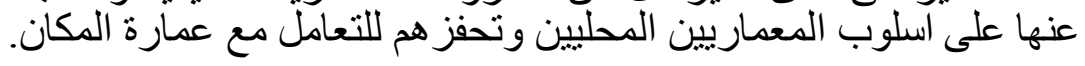

اما فيما بتعلق بالمحفزات الاقليمية غبر المعمارية، والمتمثلة بالحركات السياسية، "فان

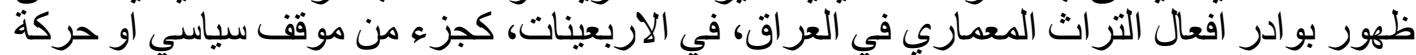

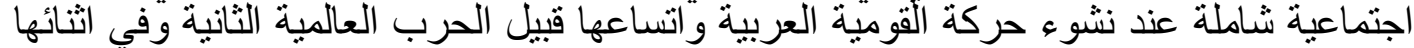

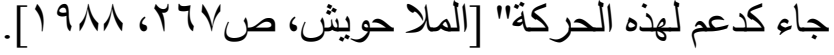

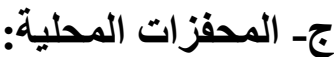

فيما يتعلق بالمحفزات المحلية (الذاتية)، فقد تمحورت ما بين محفز ات ذاتية ذاتية تخص

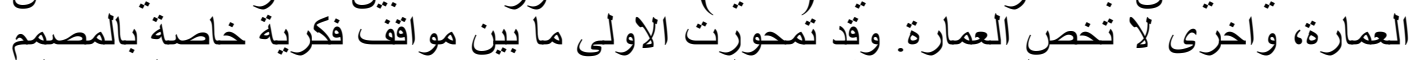

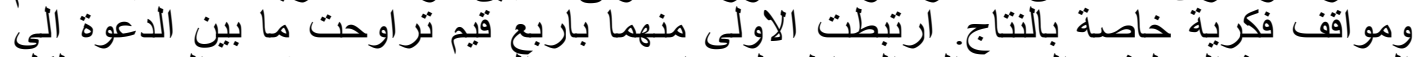

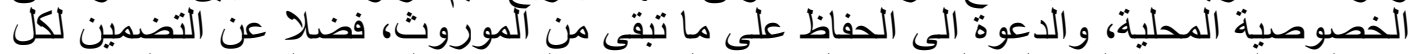

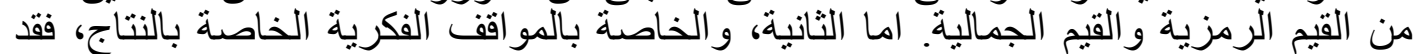

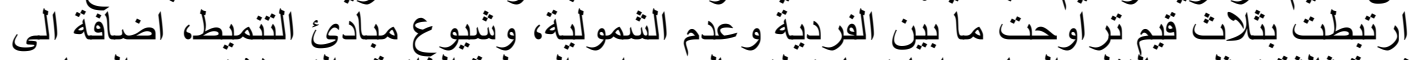

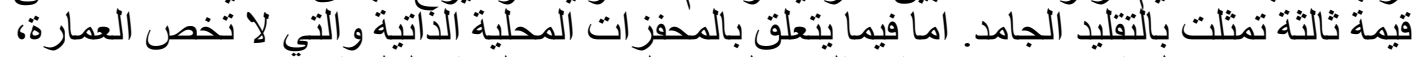

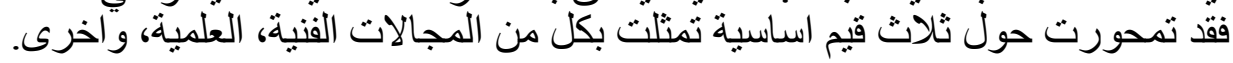

فيما يتعلق بالمحفز ات المحلية الذاتية المعمارية، المرتبطة بالمو اقف الفكرية للمصدم، والتهات والتي

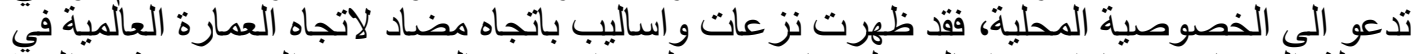

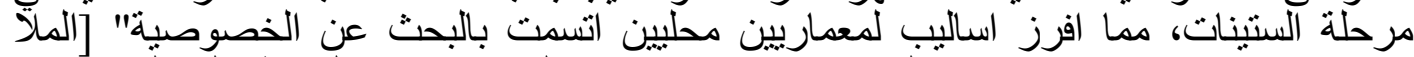

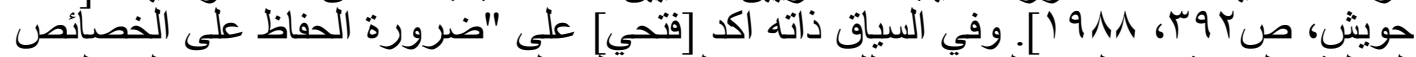

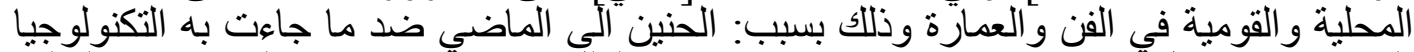

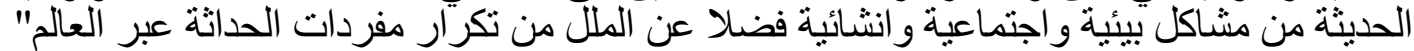

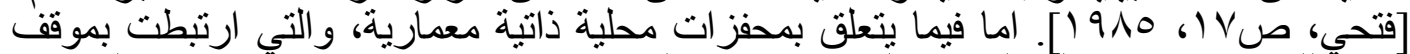

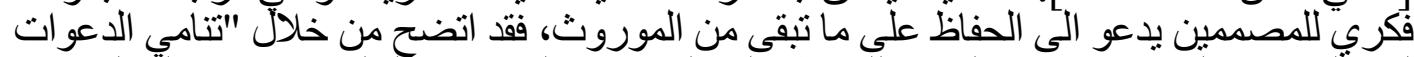

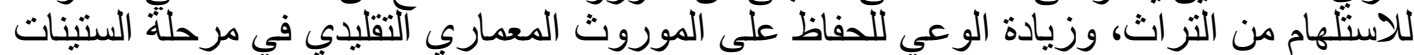

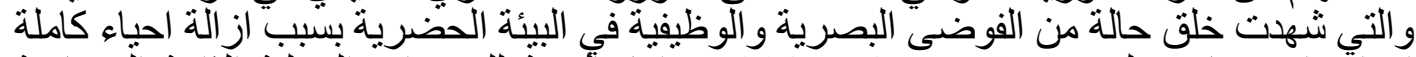

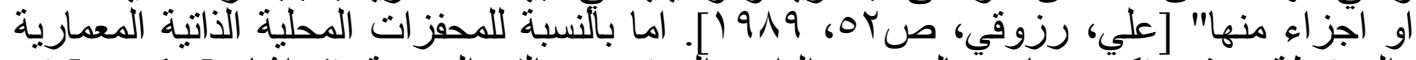

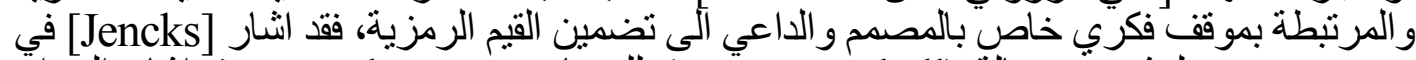

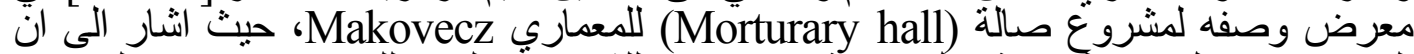

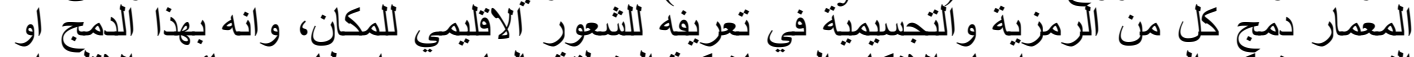

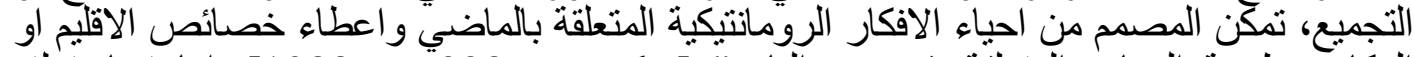

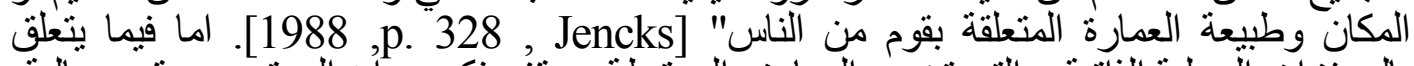

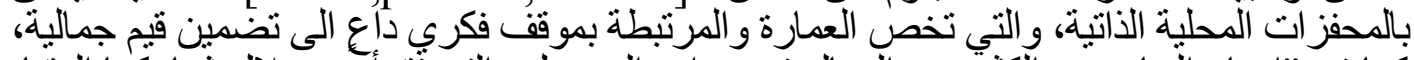

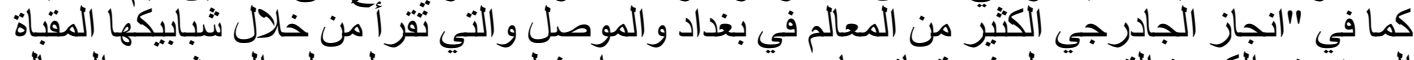

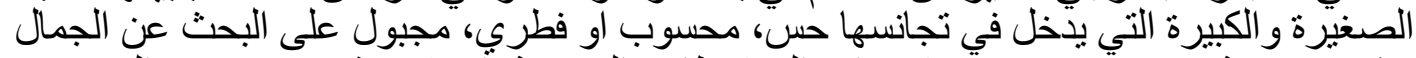

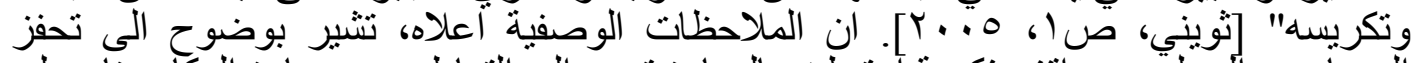

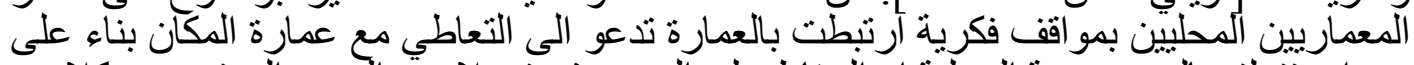

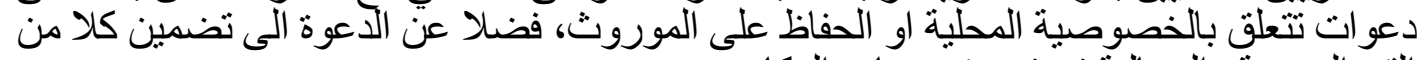
القيم الرمزية و الجمالية في تعريف عمارة الخية المكان.

اما فيما بتعلق بالمحفز ات المحلية الذاتية المعمارية و المرتبطة بمواقف فكرية خاصة

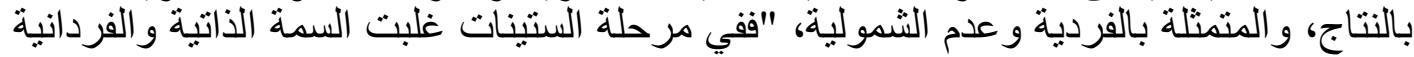




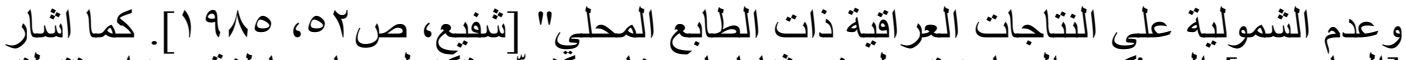

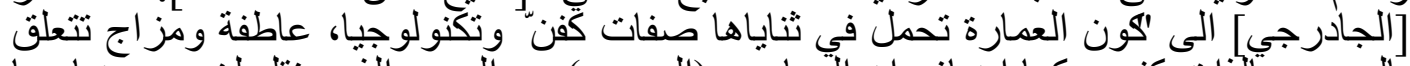

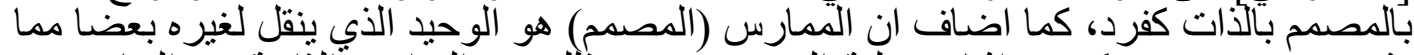

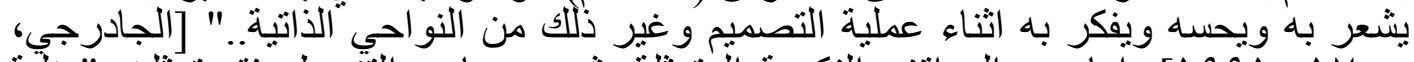

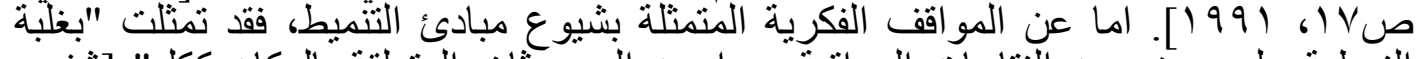

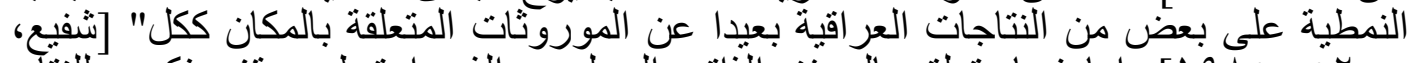

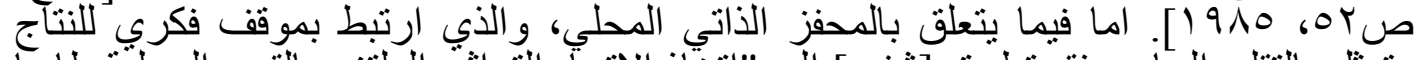

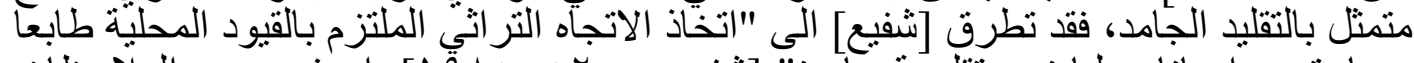

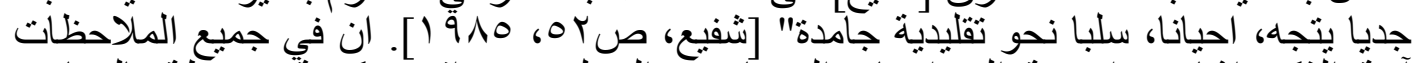

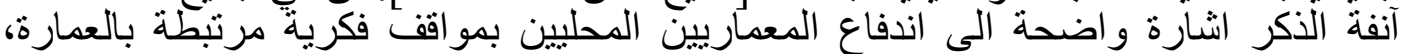

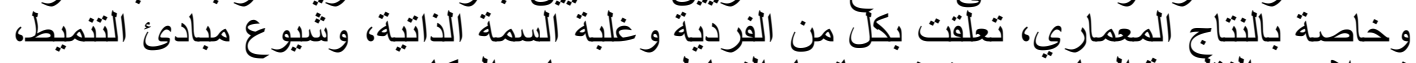

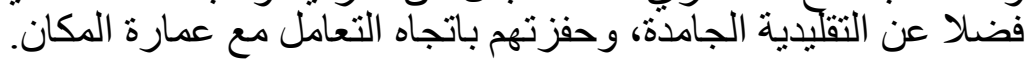

اما فيما يتعلق بالمحفز ات الذاتية غير المرتبطة بالعمارة والمتمثلة بالمجالات الفنية، فقد اثنار

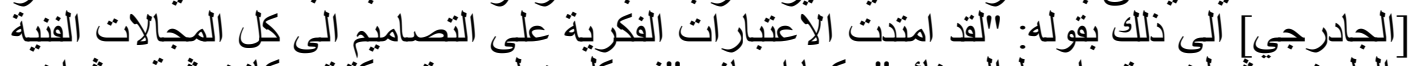

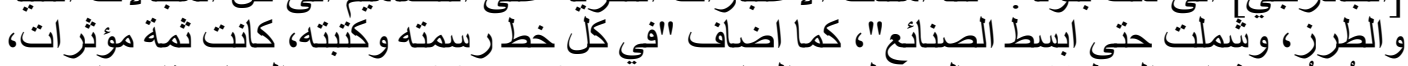

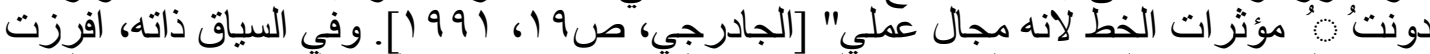

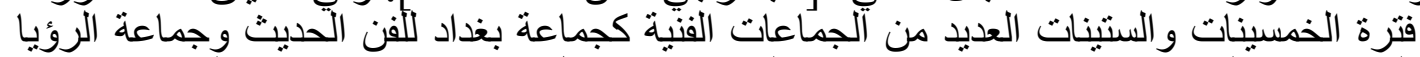

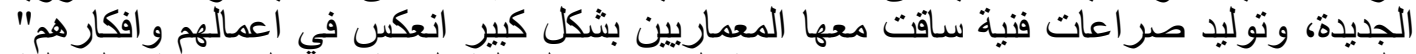

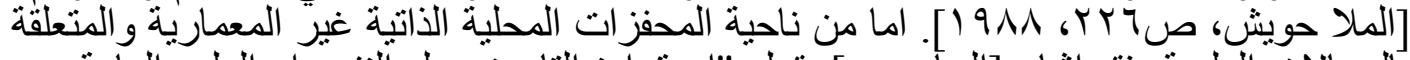

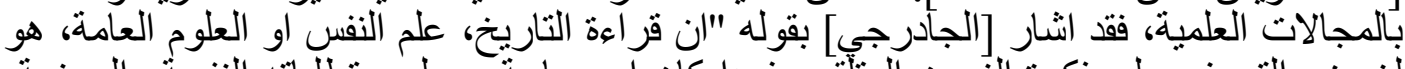

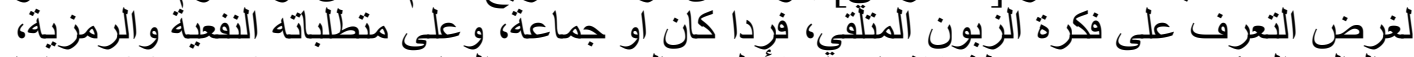

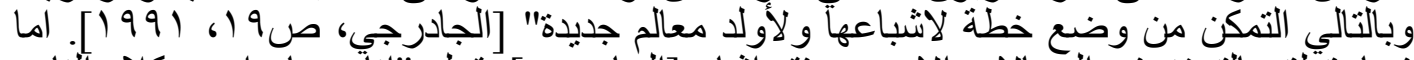

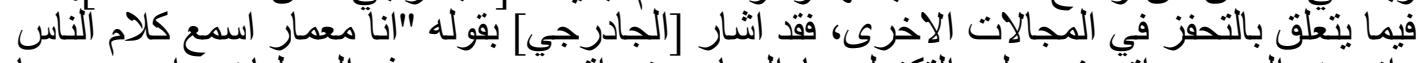

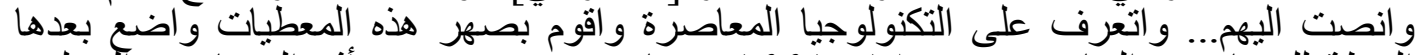

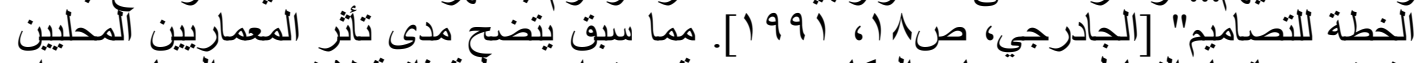

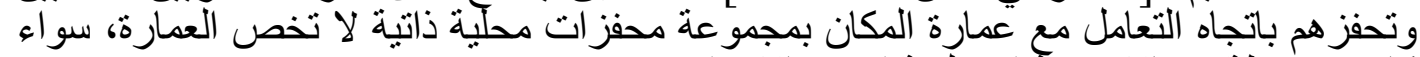

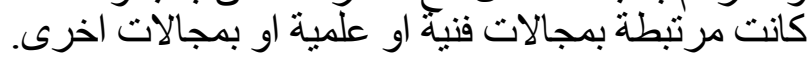

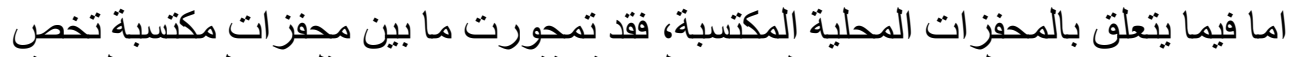

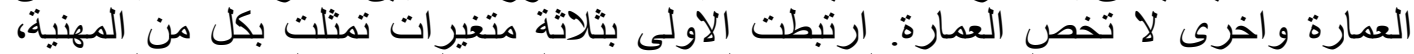

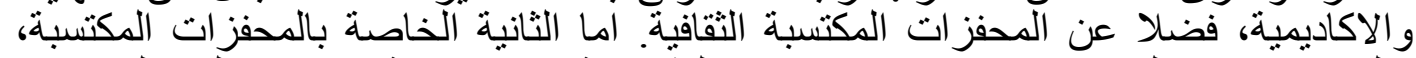

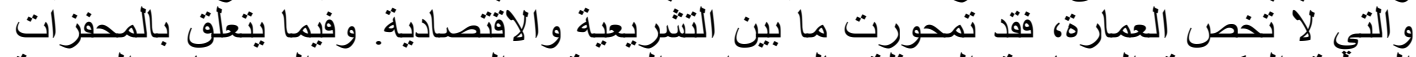

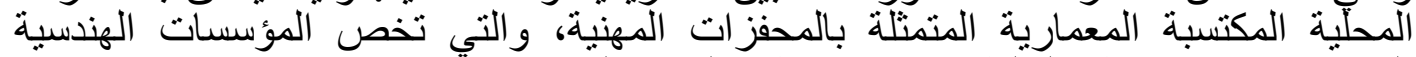

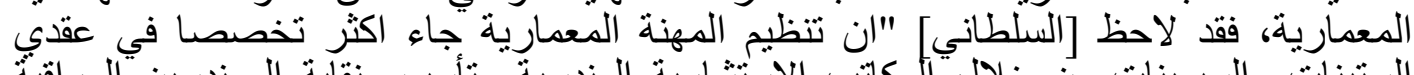

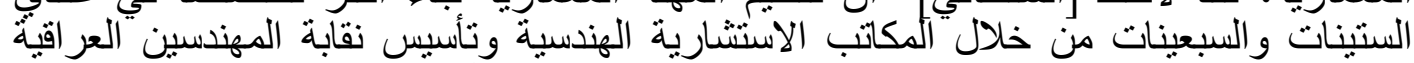

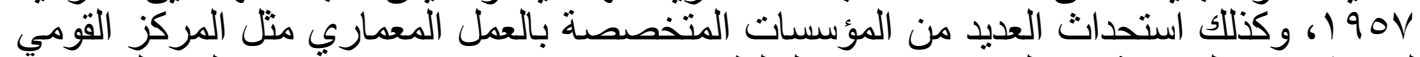

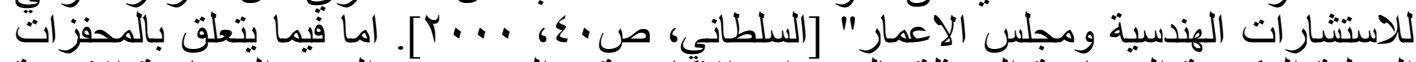

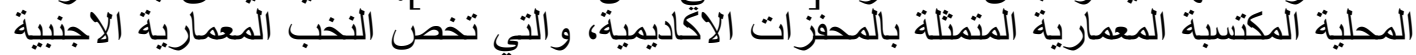

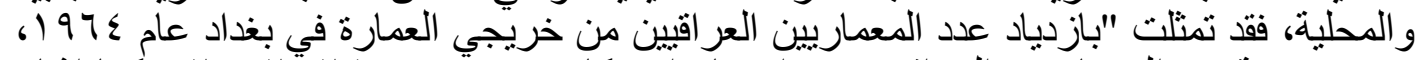

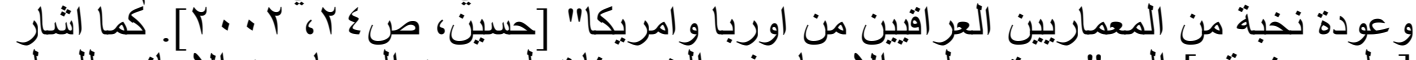

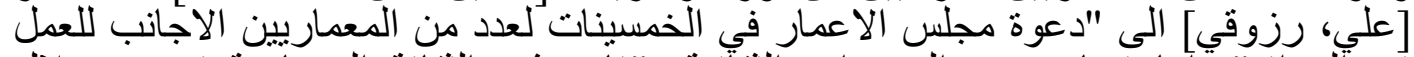

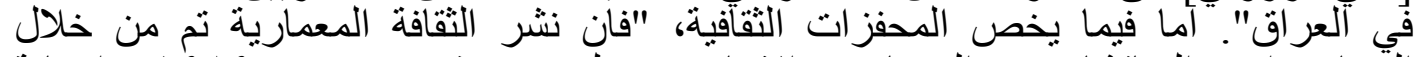

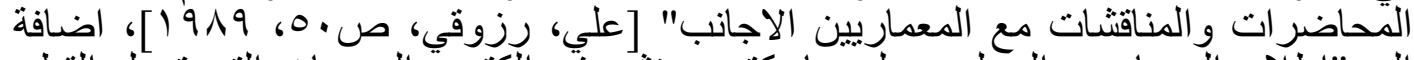

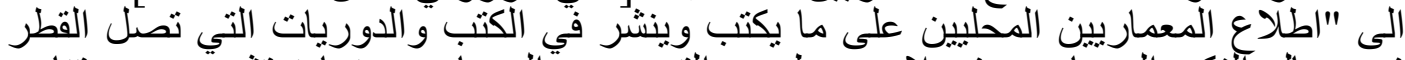

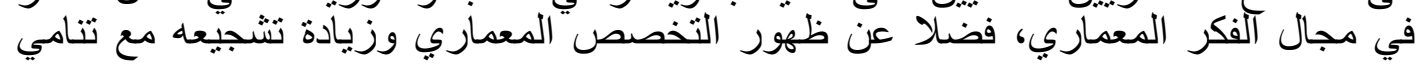




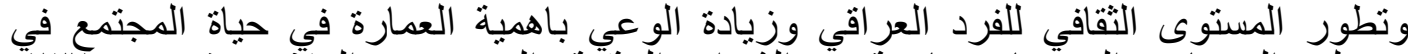

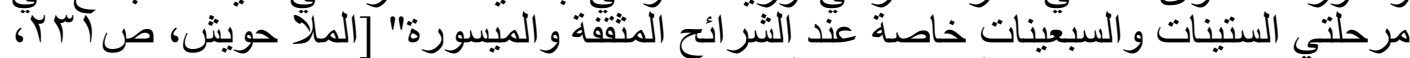

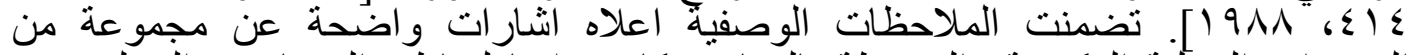

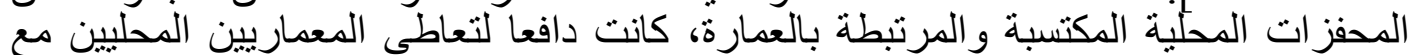

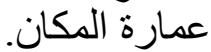

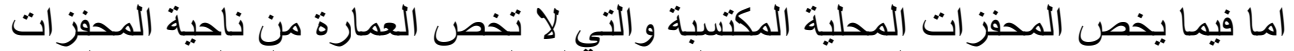

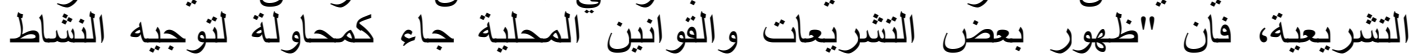

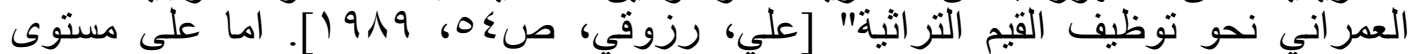

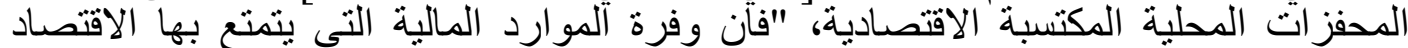

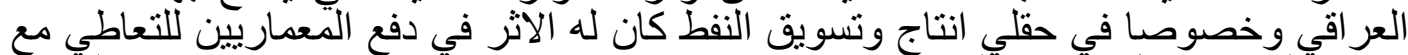

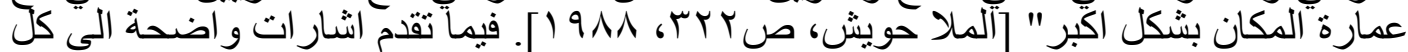
من المحفز ات التشريعية و الأقتصادية.

اما فيما يتعلق بالمحفز ات المحلية النفعية، فقد تمحورت بقيمتين اساسيتين، تمثلت الاولى المي

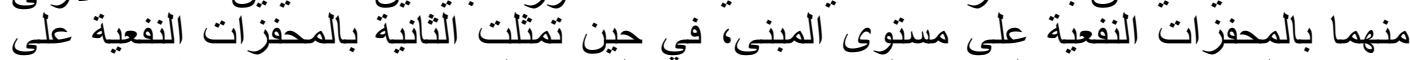

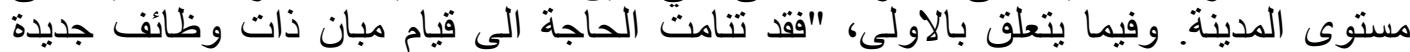

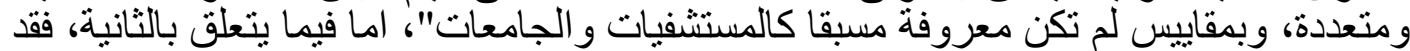

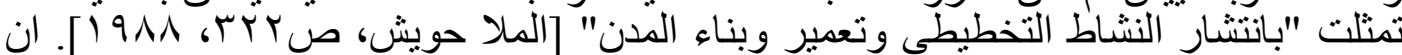

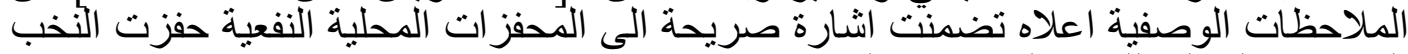
المعمارية المحلية للجوء اللى عمارة المكان.

2-1-5 المفردة الثانية/ الاعتبارات المرتبطة بعمارة المكان

تمثل الاعتبار ات مجموعة الحدود المادية و المعنوية التي يجب ان تؤخذ بنظر الاعتبار

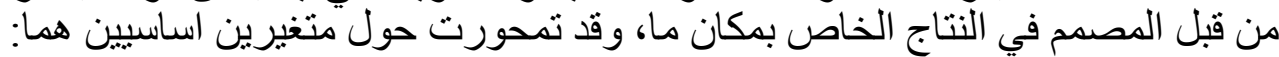

أـ الاعتبارات المادية وبدور ها فقد تمحورت حول قيم اساسية شملت كل من: النتاج، المناخ، الطبيعة الجغر افية، الطبيعة الديمو غر افية، التقنية ومو اد البناء.

بـ الاعتبارات المعنوية (الحضارية) وبدور ها فقد تمحورت حول متغيرين ثانويين هما: نوعية

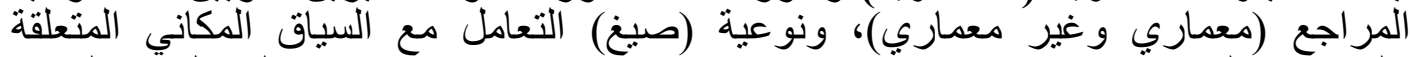

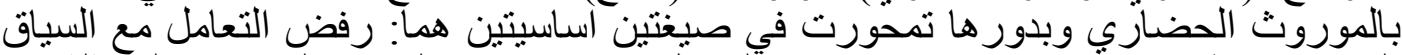

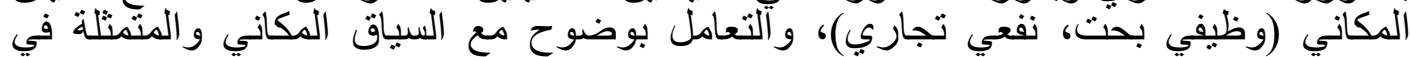

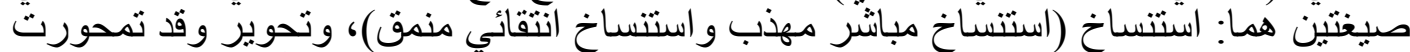

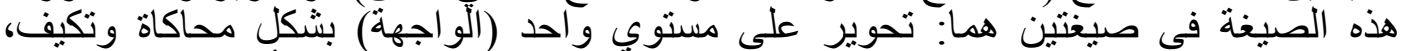

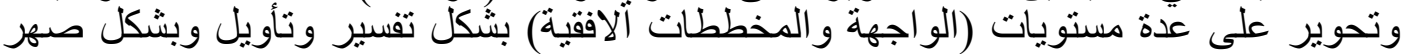
وتقطير (تجريدي وكلاسيكي) مع تباين نوعية التحوير هذه في صيغ التئية التحقق من ناحية المبادئ

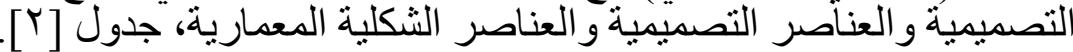

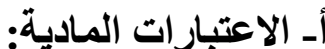

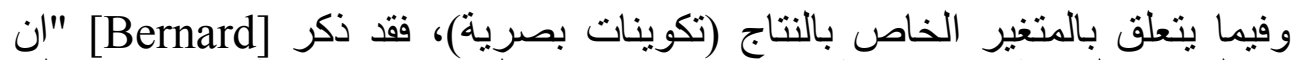

المكان في العمارة العربية والاسلامية يعتمد في مفهومه على مقدار ما يؤثر بصريا وفلى فيلى 


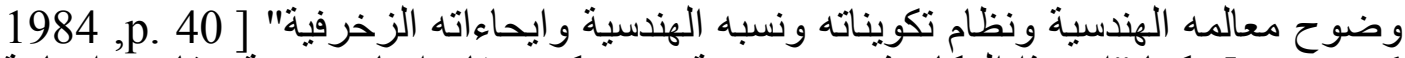

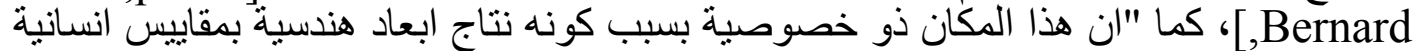

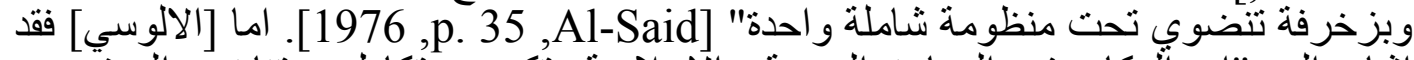

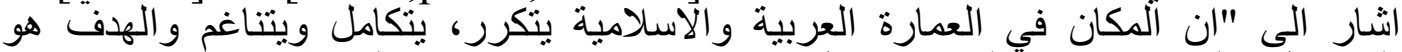

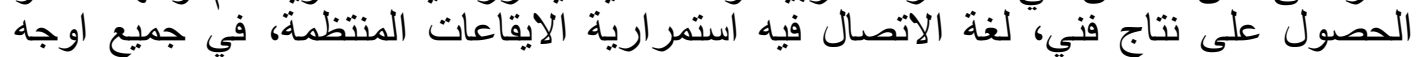

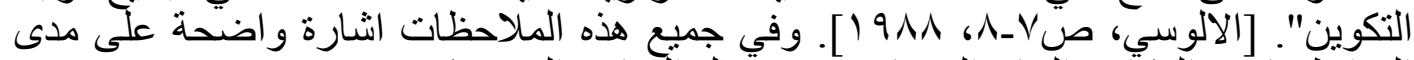

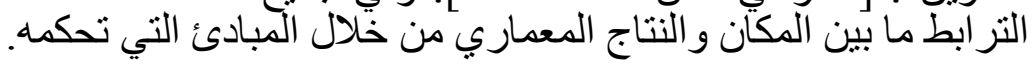

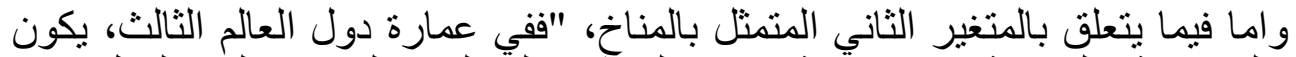

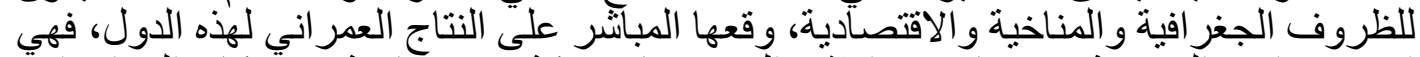

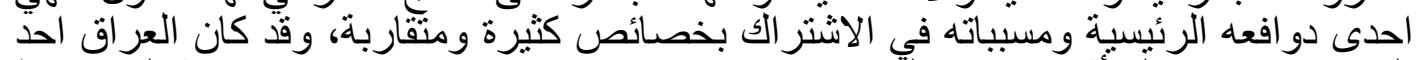

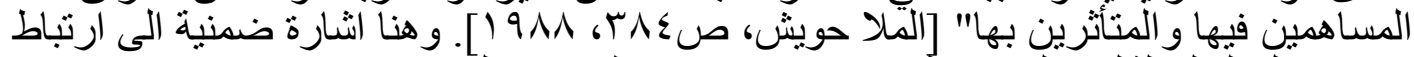
عمارة دول العالم الثالث بالمناخ و الذّي بدوره يعني ارتباط عمارة المكان بمناخه.

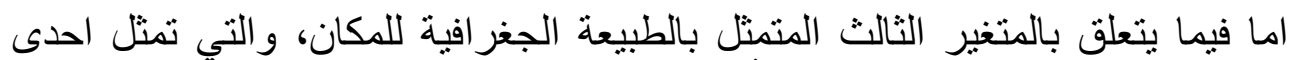

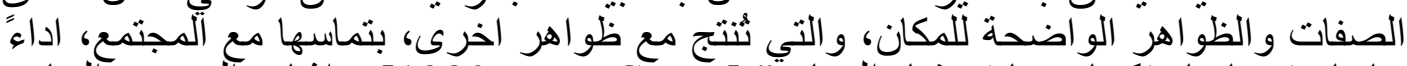

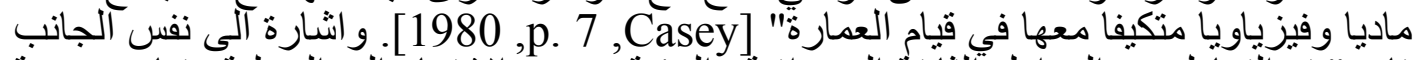

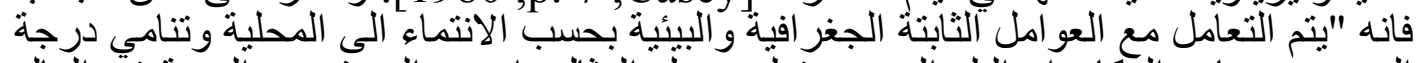

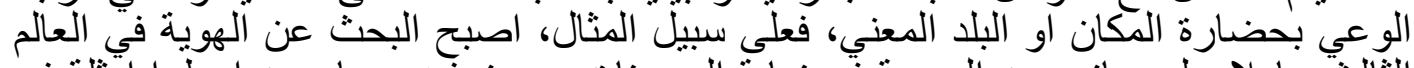

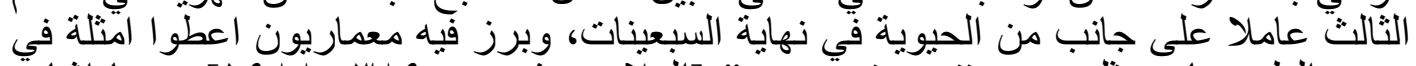

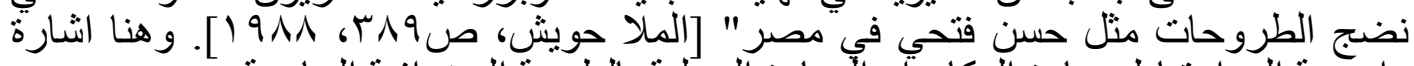
و اضحة الى ارتباط عمارة المكان أو التعمارة المحلية بالطبيعة الجغر افية الخاصة بهاه.

و واما فيما يتعلق بالمتغير الر ابع المتمثل بالطبيعة الديمو غر افية (الانسان المنتمي لمكان المان

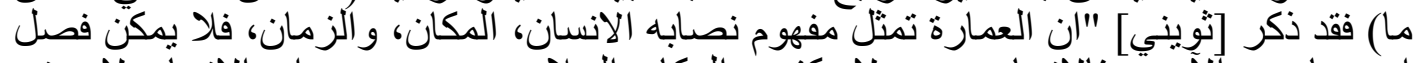

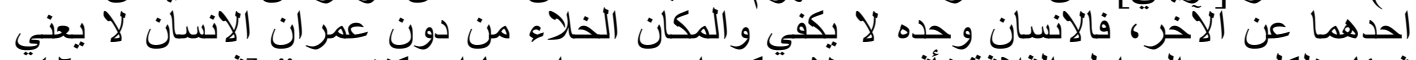

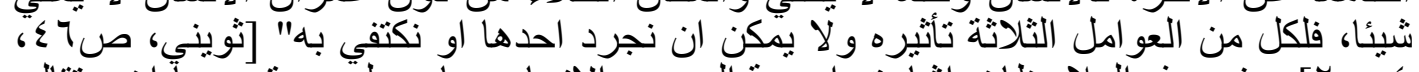

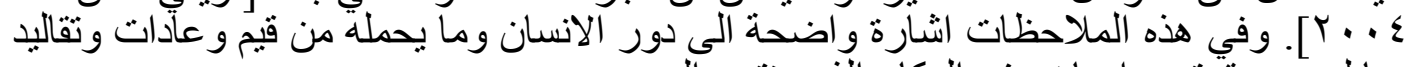

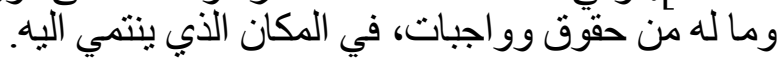

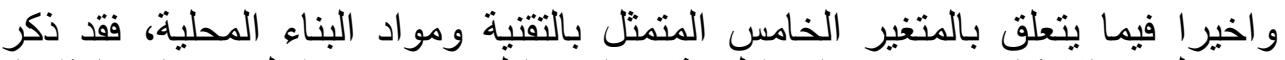

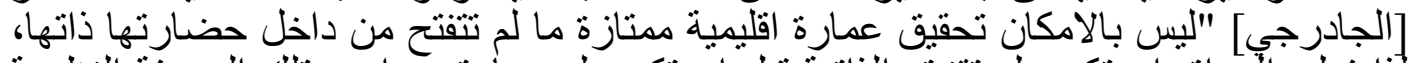

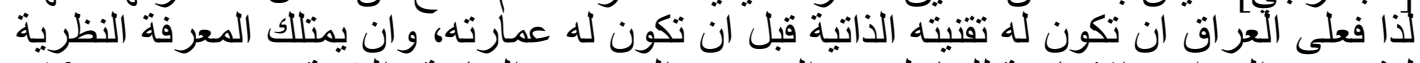

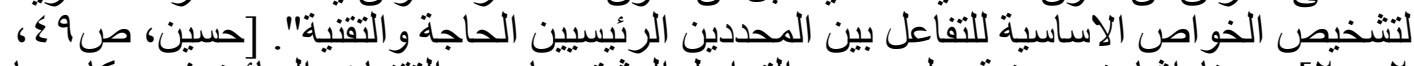

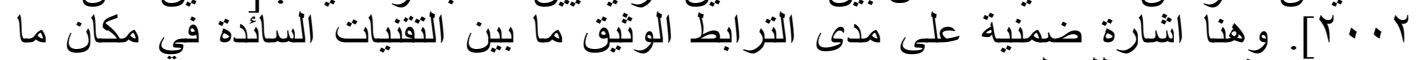
وخصوصية عمارة ذلك المكان.

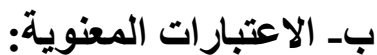

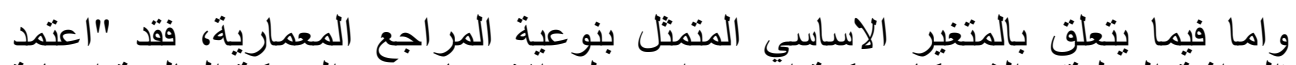

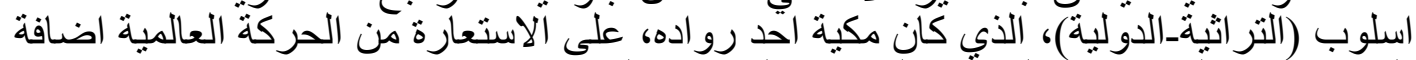

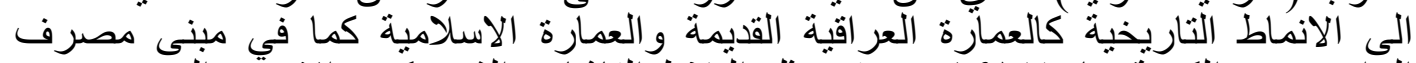

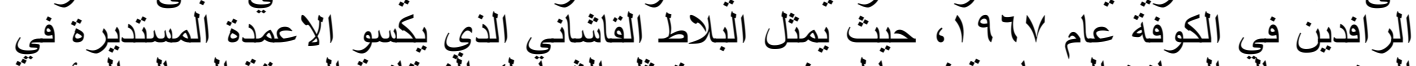

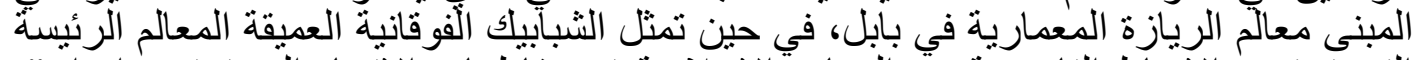

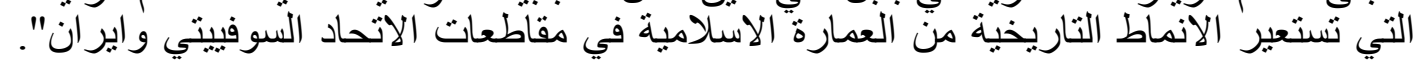




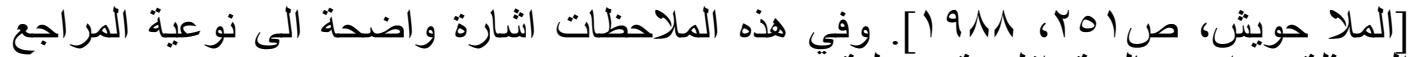
المنمثلة بمر اجع عالمية، اقليمية ومحلية.

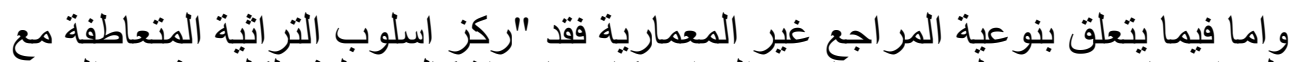

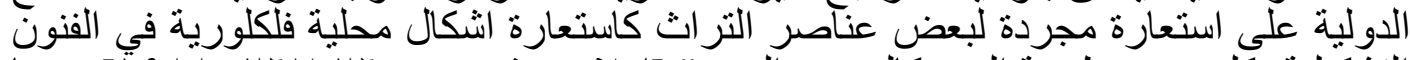

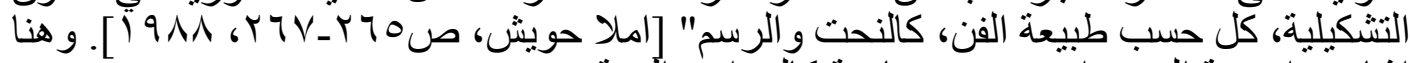
اشارة واضحة الى مر اجع غير معمارية كالمر اجع الفنية.

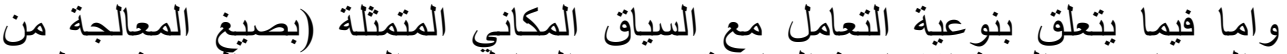

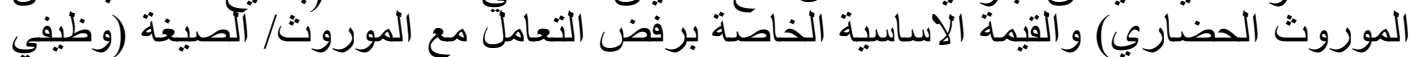

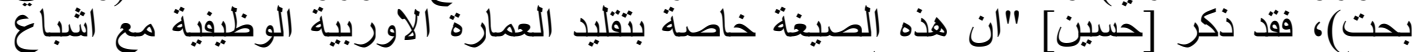

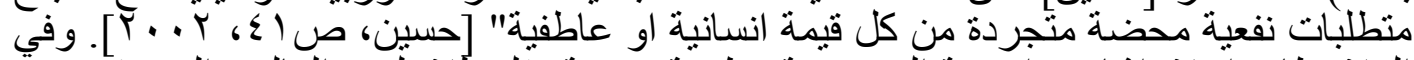
الملاحظات اعلاه اشارة و اضحة الى صيغة وظيفية صلية صرفة مقلدة للاسلوب العالمي الحديث.

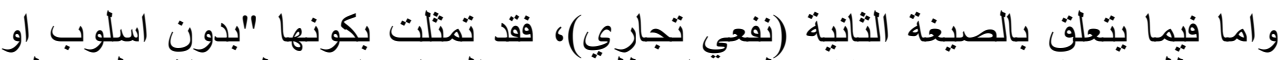

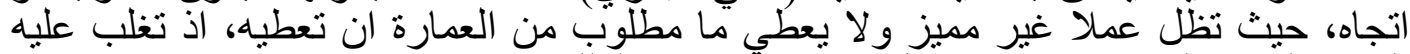

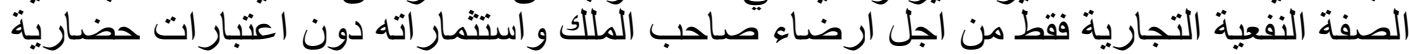

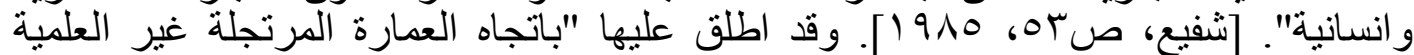

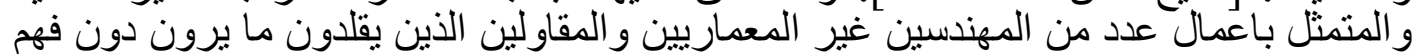

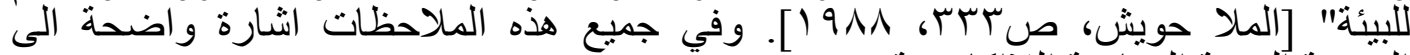

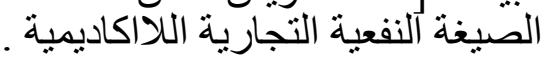

وكنتيجة لهذه الصيغة المتمثلة برفض التعامل مع السياق المكاني المتعلقة (بصيغ التماني

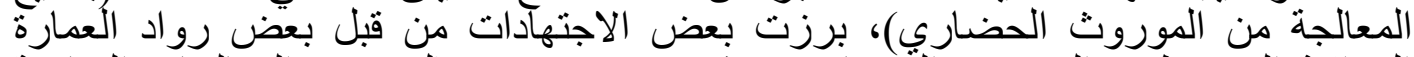

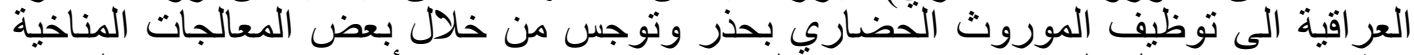

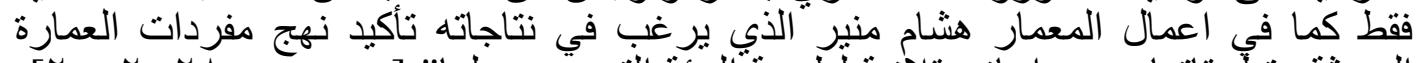

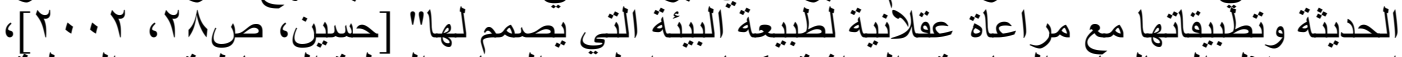

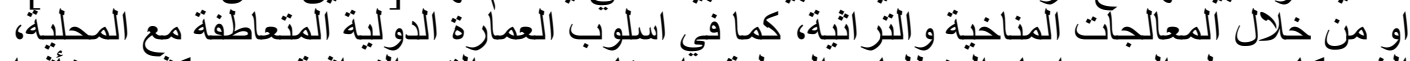

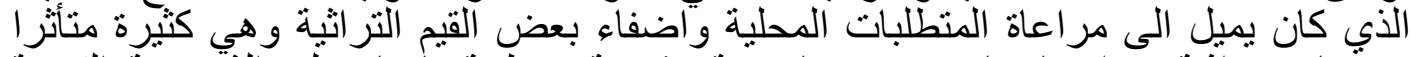

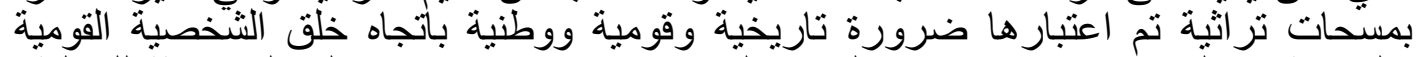

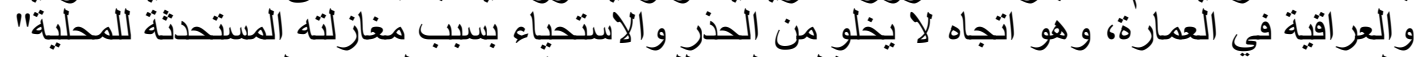

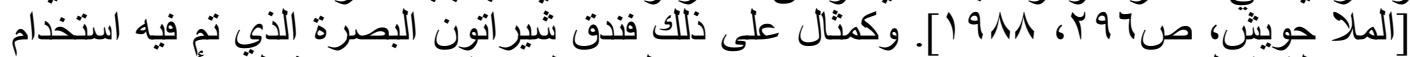

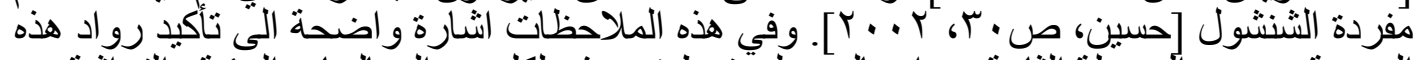

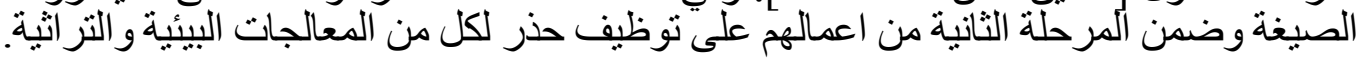

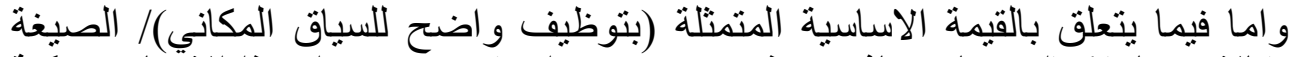

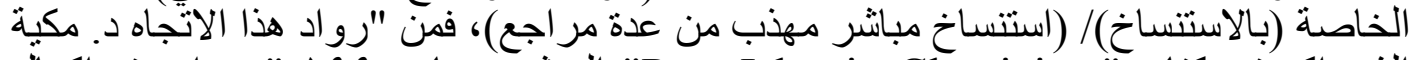

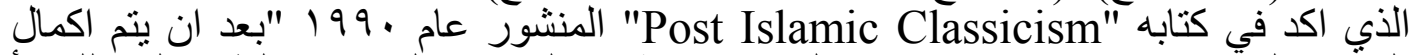

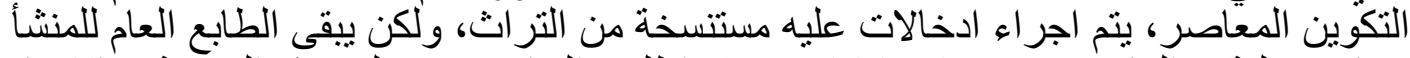

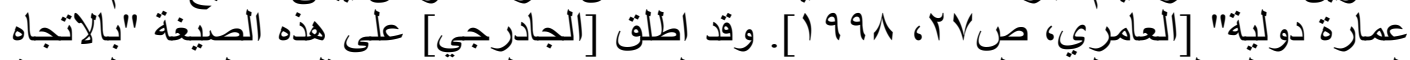

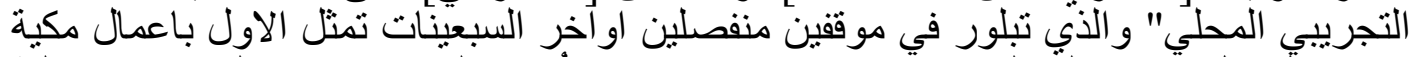

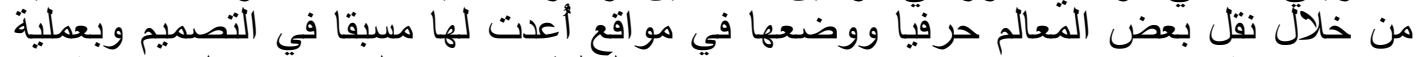

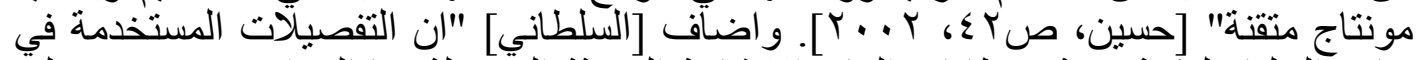

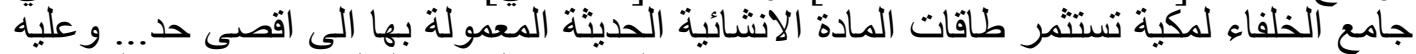

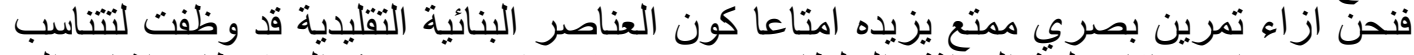

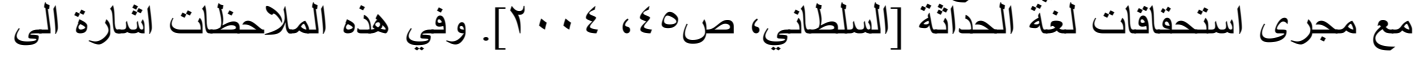


توظيف و اضح للعناصر التراثية من خلال صيغة الاستنساخ الحرفي ولكن بشكل مهذب و اقحامها على التكوين الّعاصر في مو اقع مدروسة معتمدا اسلوب العمل الحرفي الزخرفي.

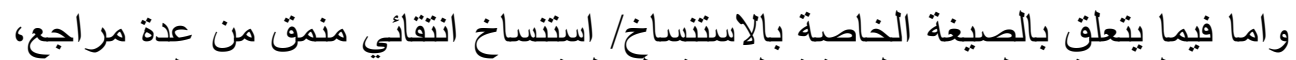

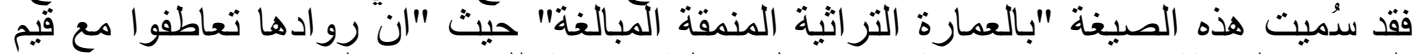

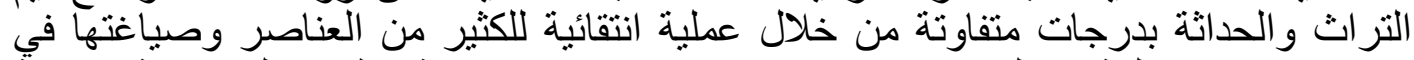

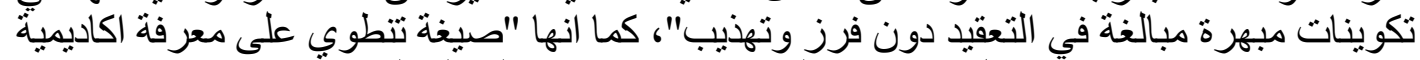

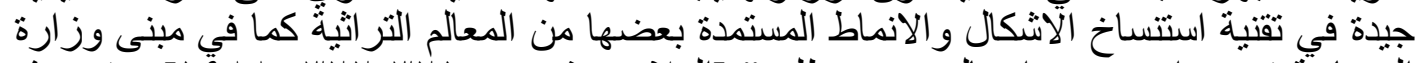

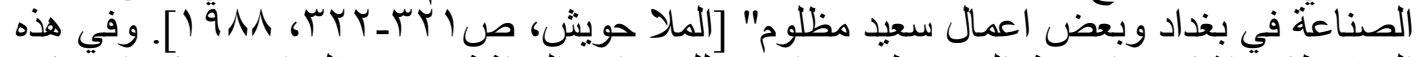

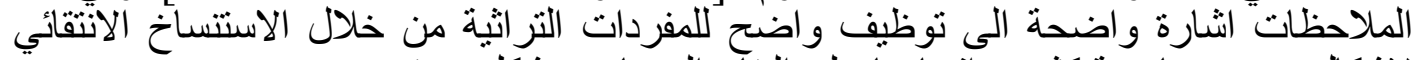

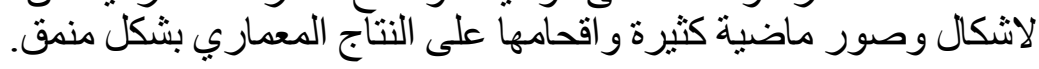

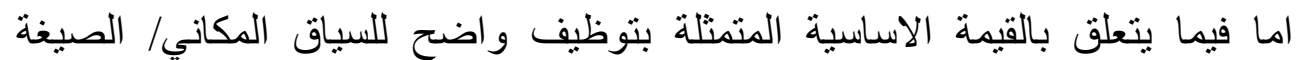

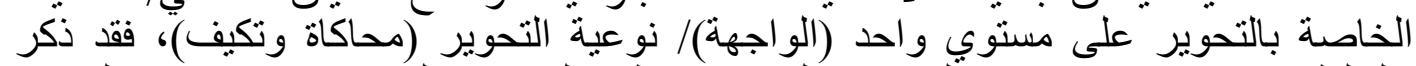

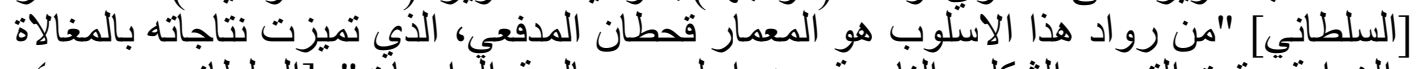

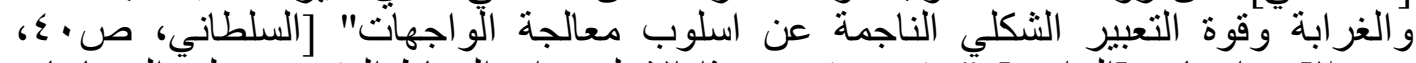

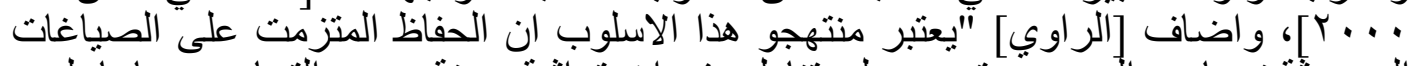

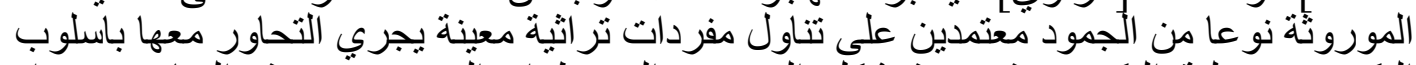

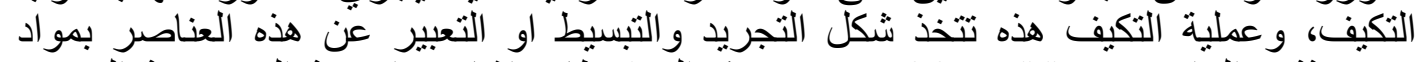

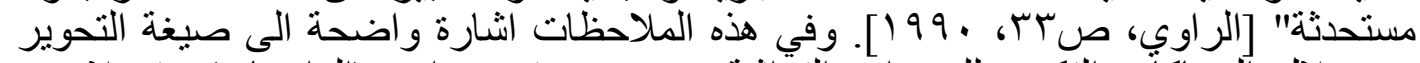

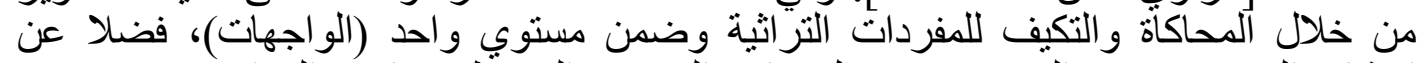
الاشتارة الى صيغ تحقق التحوير من خلال مبادئ التجريد و التبسيط و عناصر المو ادئ اد.

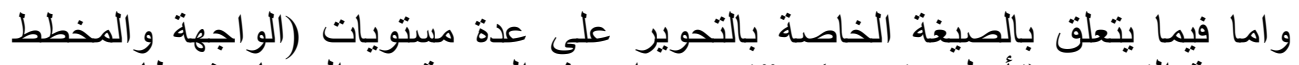

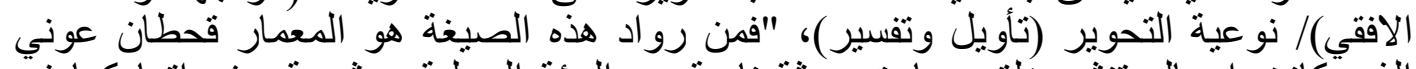

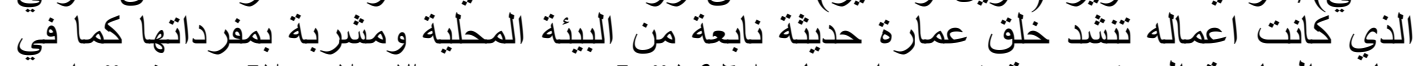

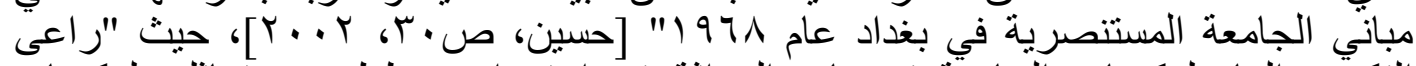

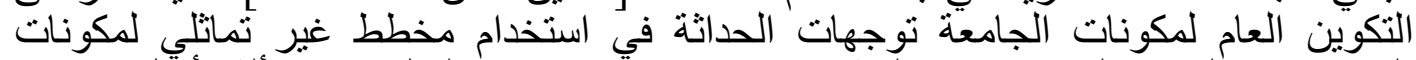

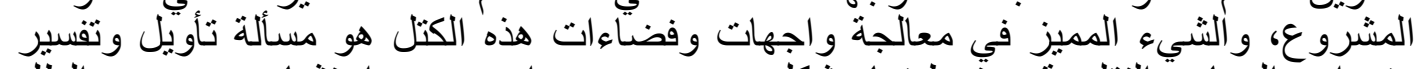

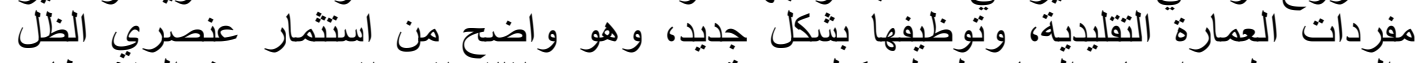

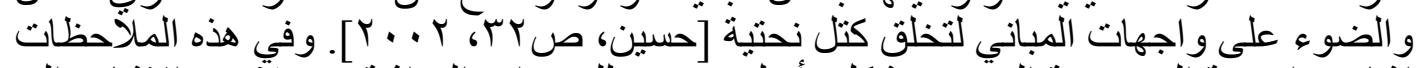

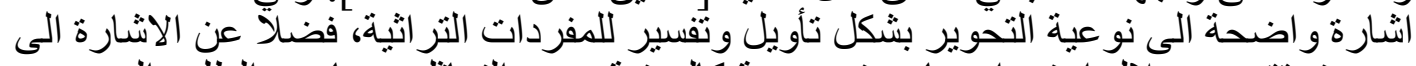

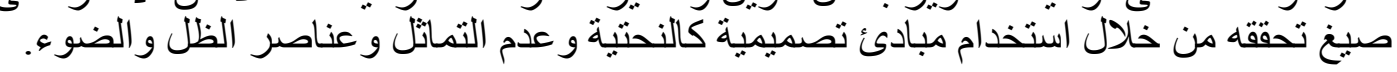

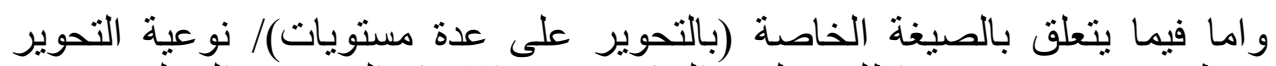

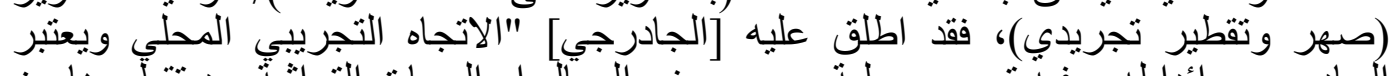

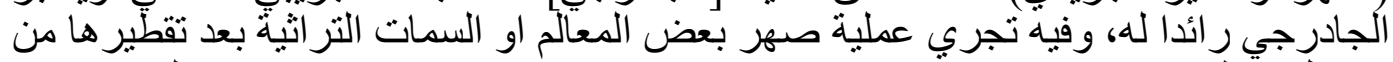

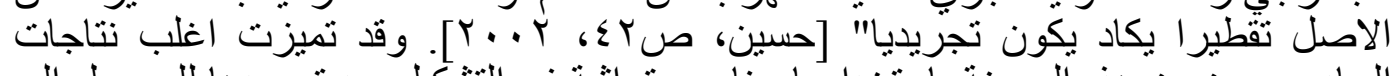

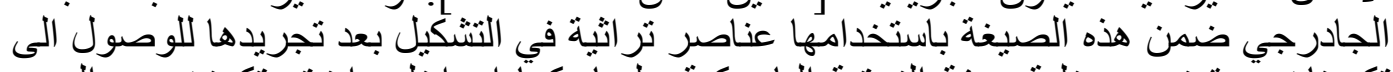

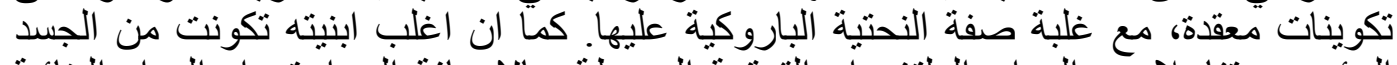

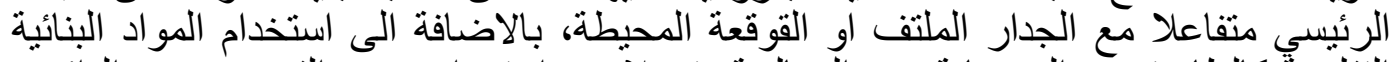

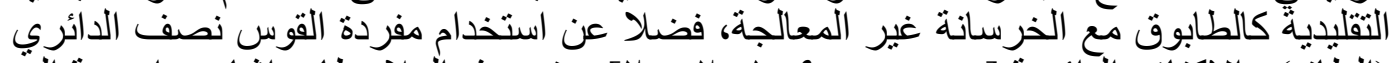

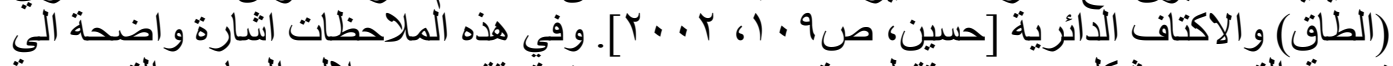
نوعية التحوير بشكل صهر وتقطير تجريدي مع صيغ تحققه من خلال المبادئ التصميمية 
كالنحتية، و العناصر التصميمية كالمواد المحلية، فضلا عن توظيف العناصر الثنكلية المعمارية كالاكتاف المستديرة و الطناف النقاق

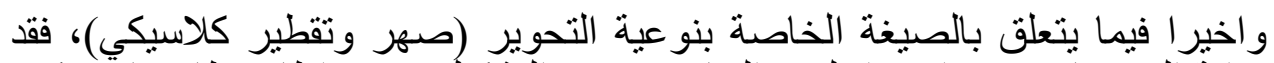

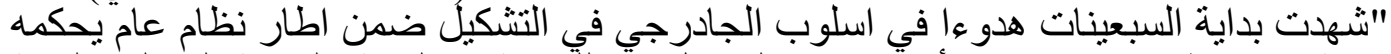

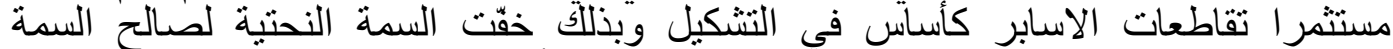
الموندريانية ولصالح المخطط النفعي آلوظيفي، حيث بدأت عملية التجريد تنتقل من مرحلة

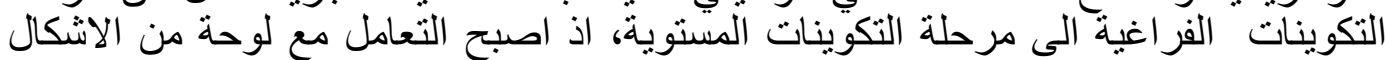

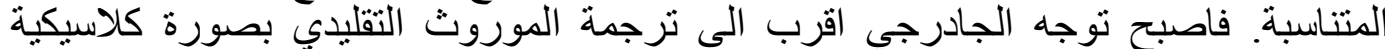

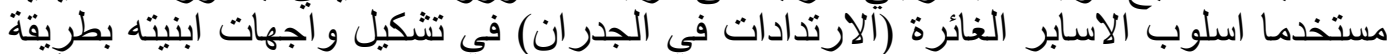

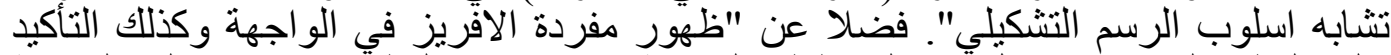

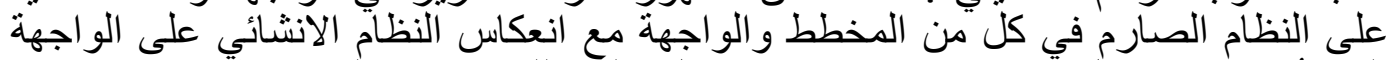

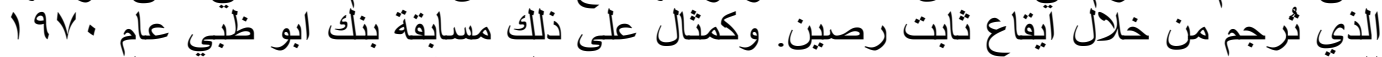

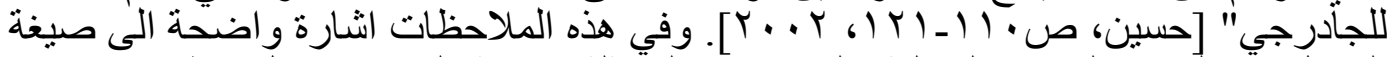

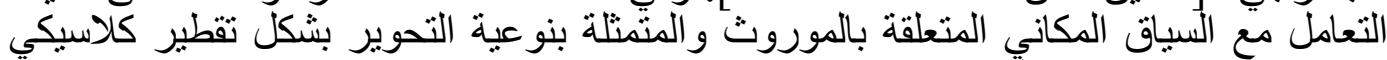
وصيغ تحققه في نتاجات الجادرجي.

جدول [ץ] المفردة الثانية/ مفردة الاعتبارات المرتبطة بعمارة المكان (المصدر/ الباحث)

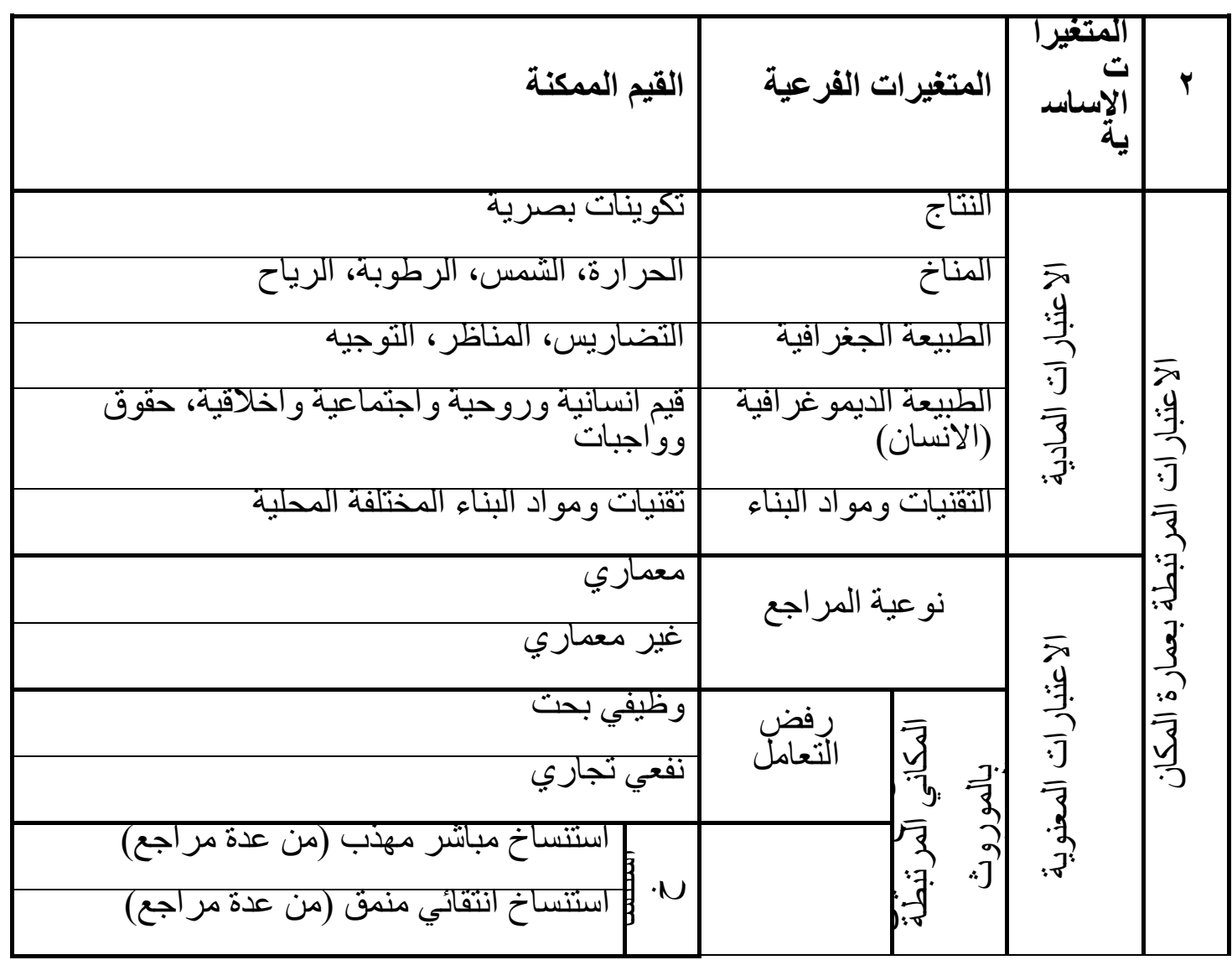




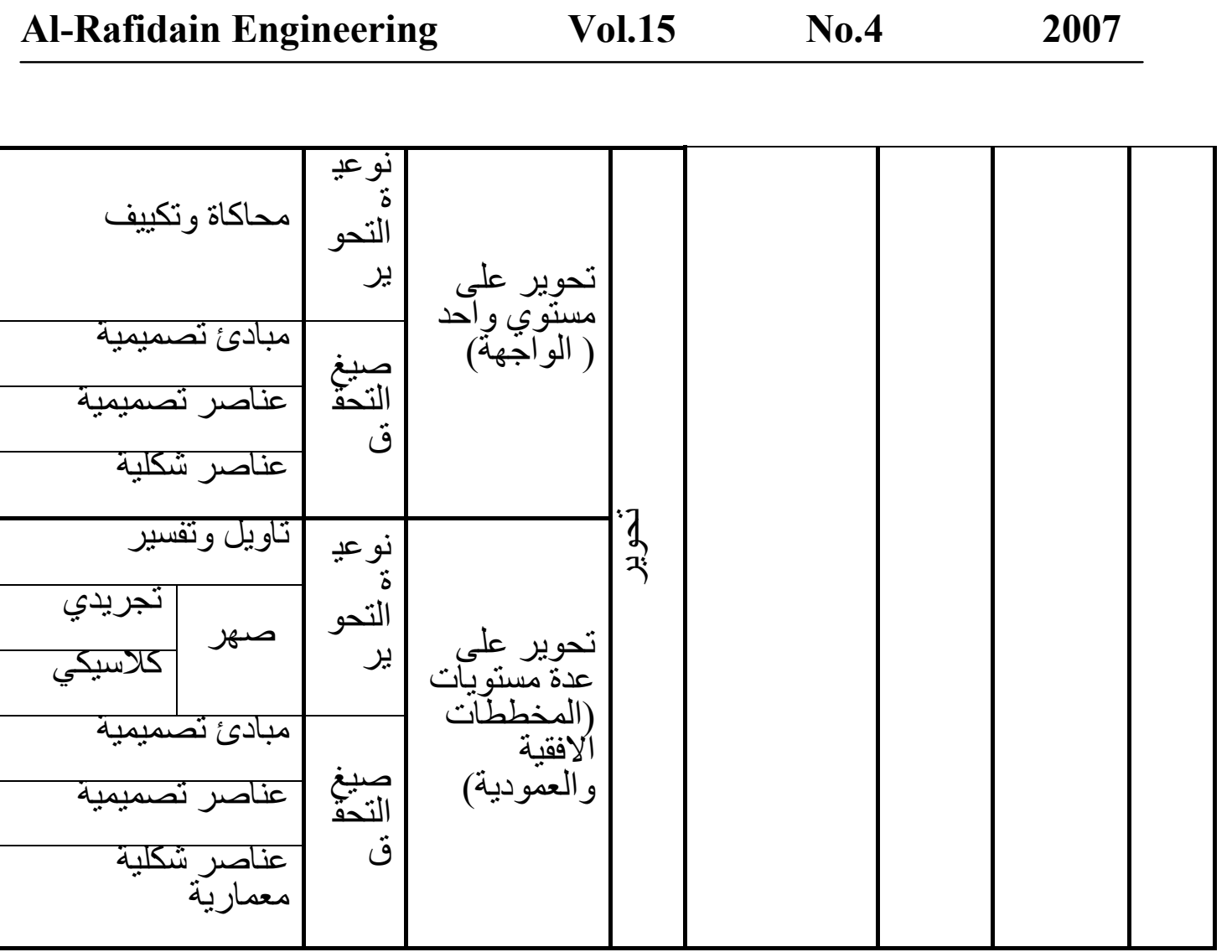

6 - 6 - 6 - 6 - 6بيق

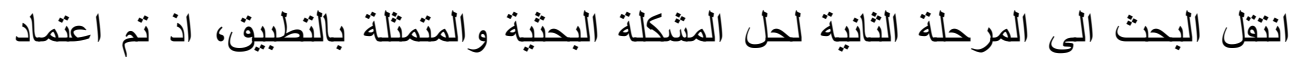

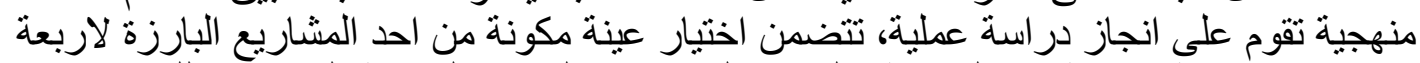

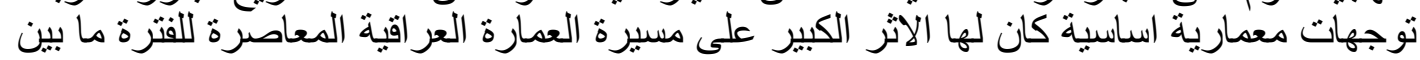

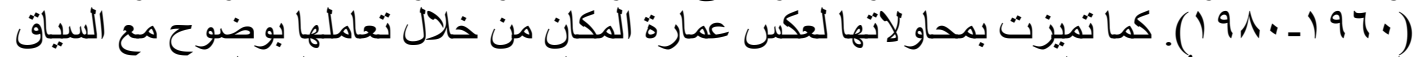

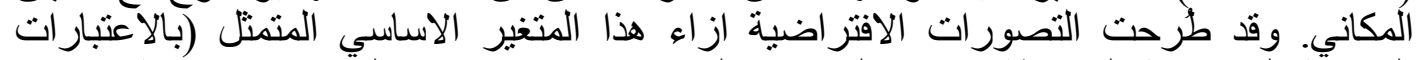

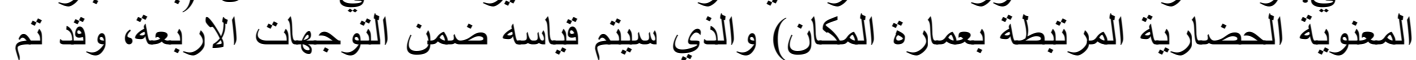

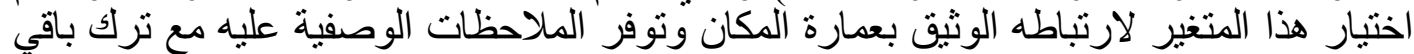

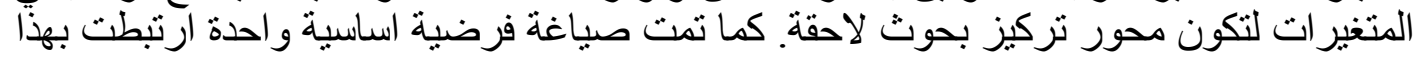

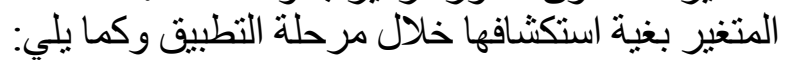

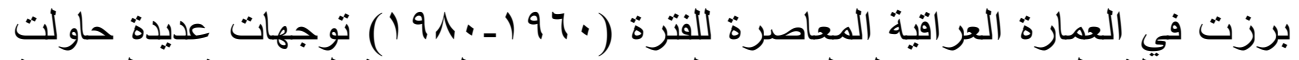

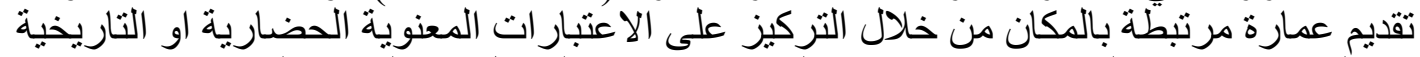

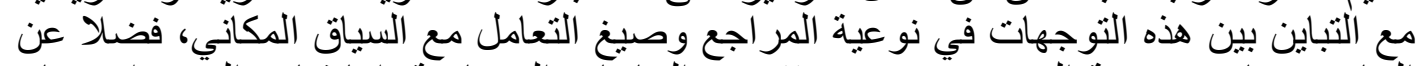

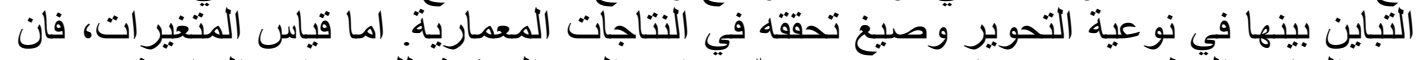

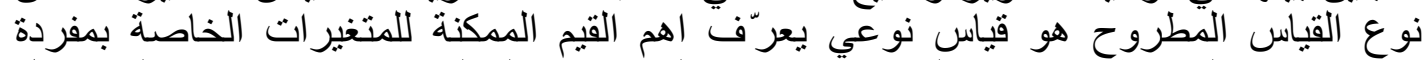

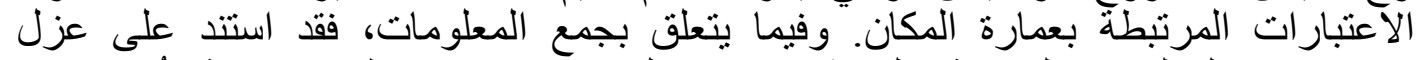

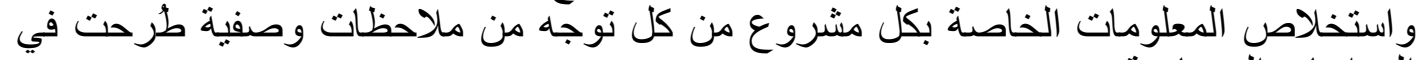

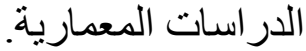




$$
\text { اما المشاريع المنتخبة فهي: }
$$

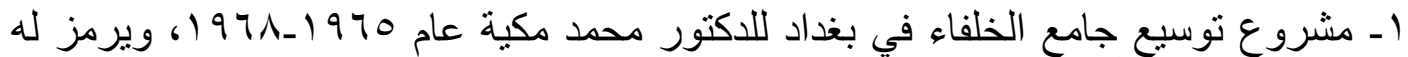

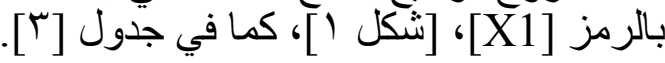

r- مشروع مبنى جمعية الفنانين العراقيين في بغداد للمعمار قحطان المدفعي عام ع 1971)،

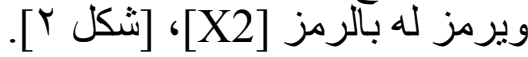

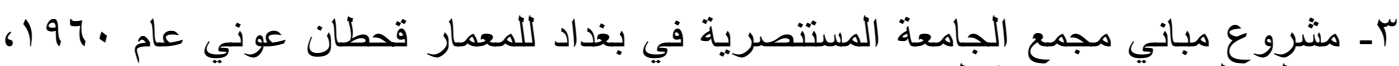

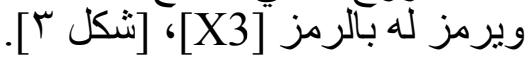

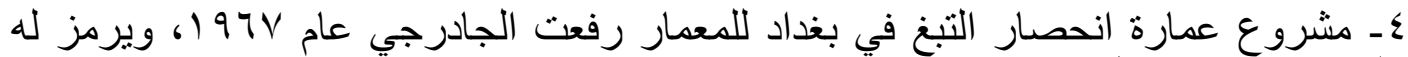

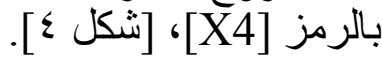
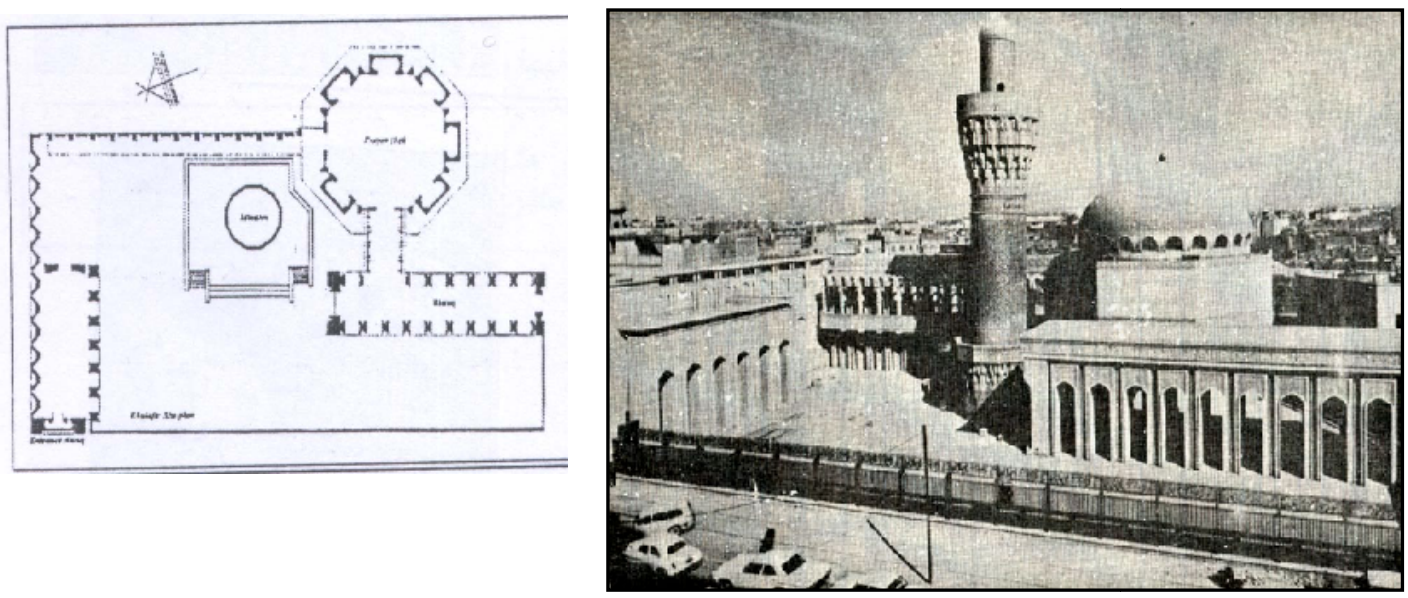

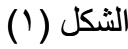

مشروع توسيع جامع الخلفاء في بغداد

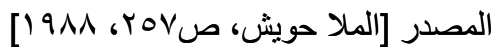

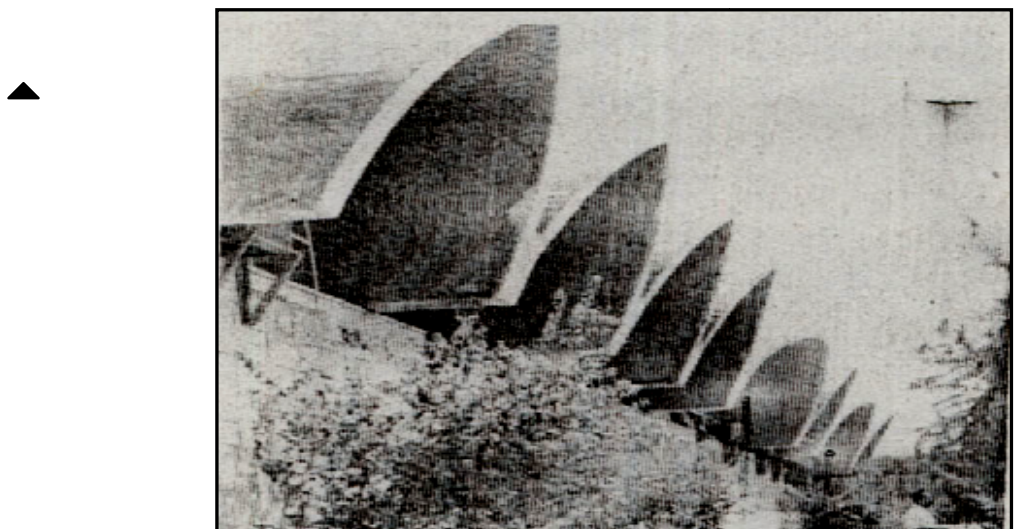




\begin{tabular}{llll} 
Al-Rafidain Engineering & Vol.15 & No.4 & 2007 \\
\hline
\end{tabular}

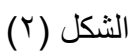

\author{
مشروع مبنى جمعية الفنانين العر اقيين في بغداد

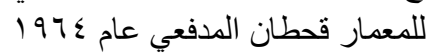

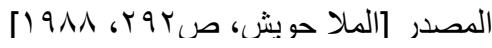

وقد تم اختبار هذه المشاريع استتادا الى تميز كل منها، وكونهم من الاعمال الاكثر اهمية وبروزا

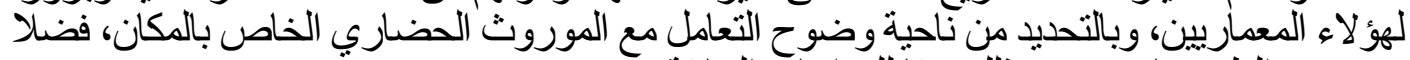
عن وفرة الطروحات عنهم وذلك وفقا للار اسات السابقة.

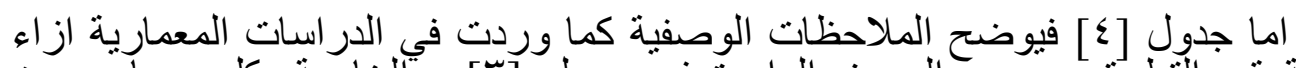

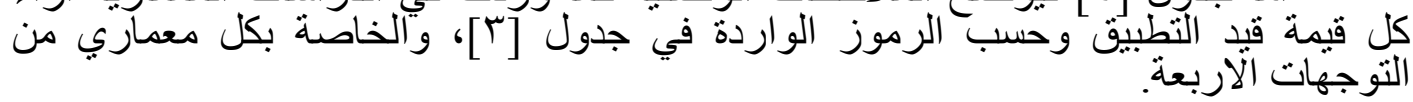




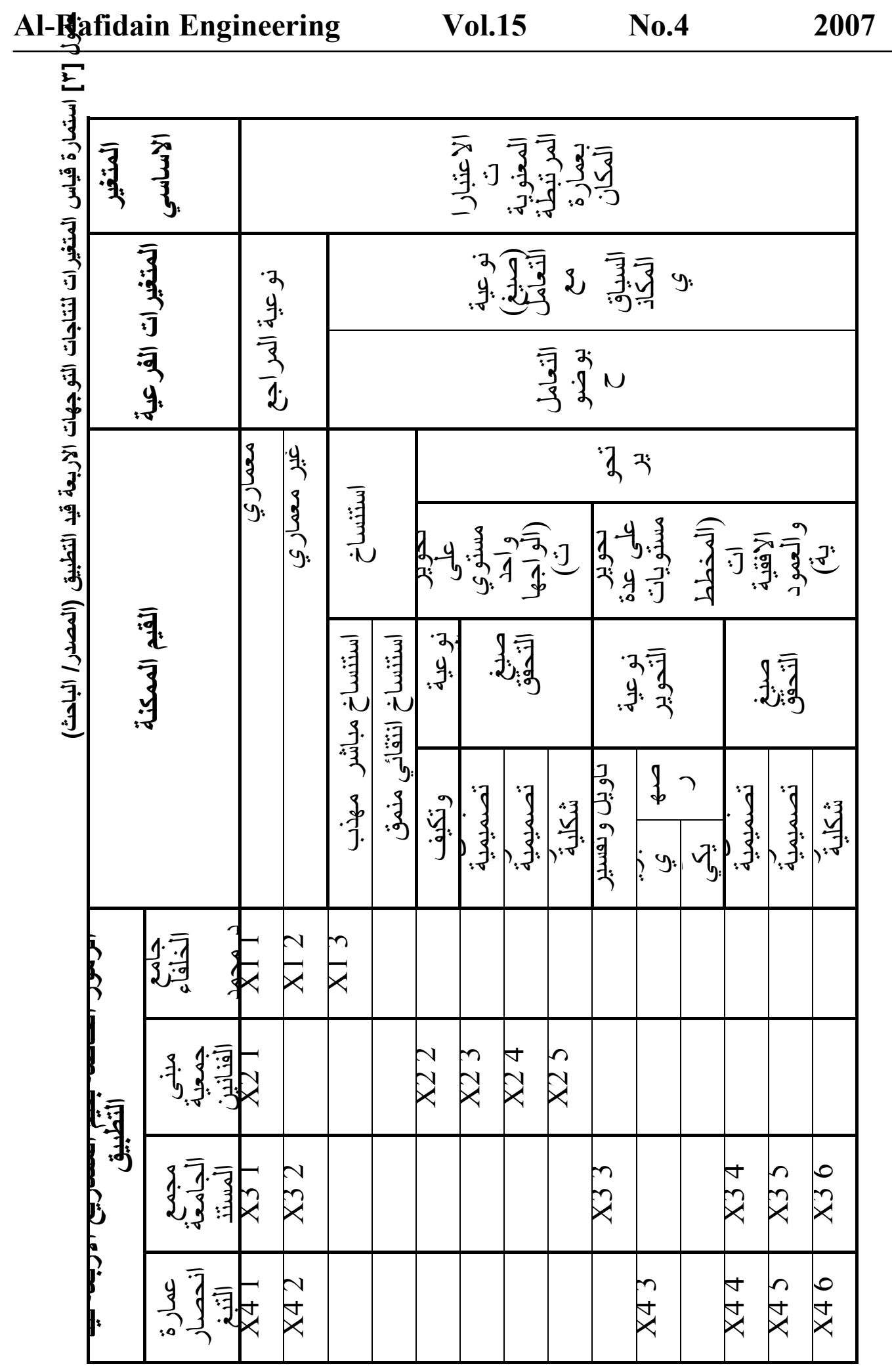


جدول [ ؛] استمارة قياس المتغيرات لنتاجات التوجهات الاربعة قيد التطبيق

\begin{tabular}{|c|c|}
\hline 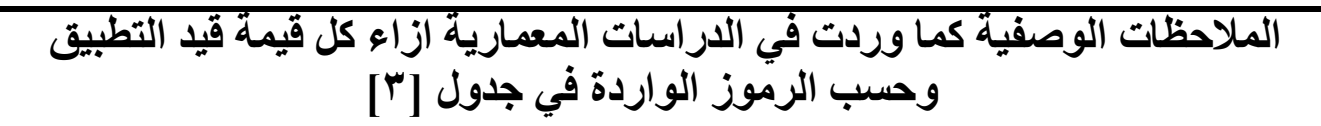 & الرموز \\
\hline محمد مكية & X1 \\
\hline 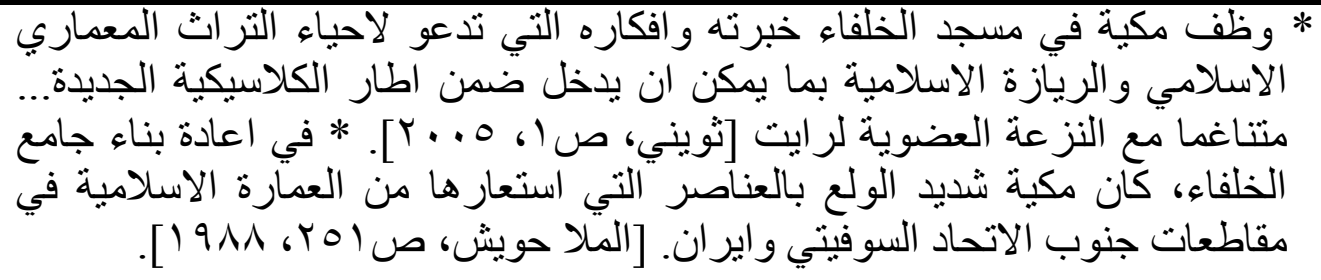 & X1 1 \\
\hline 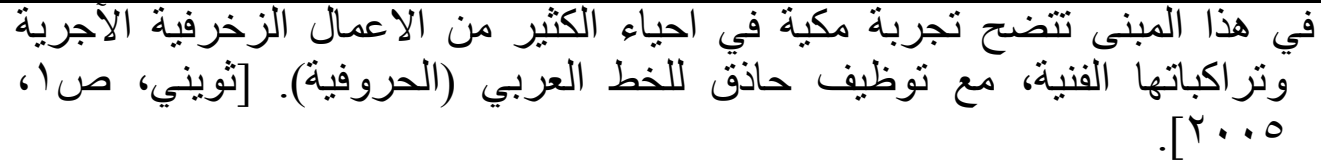 & X1 2 \\
\hline 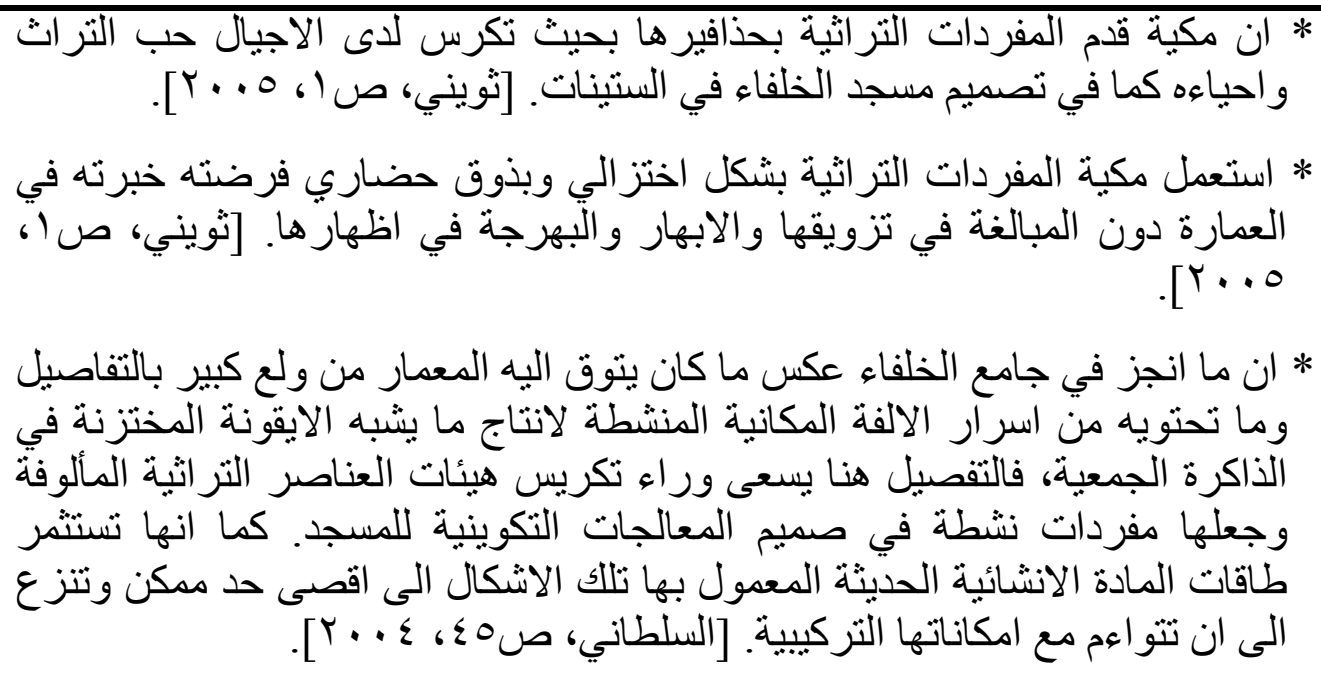 & X1 3 \\
\hline مدفعي عام V7 97 & $\mathrm{X} 2$ \\
\hline 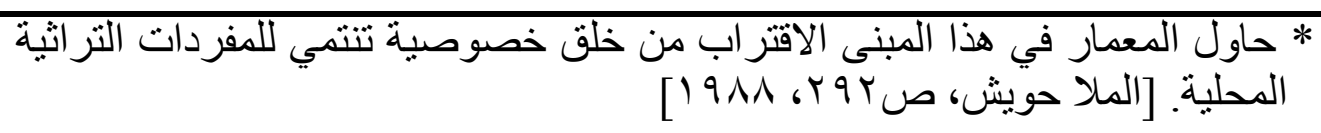 & X21 \\
\hline 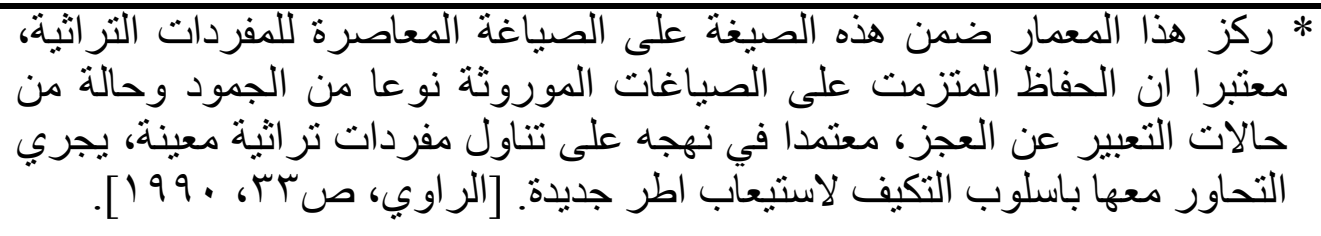 & X2 2 \\
\hline 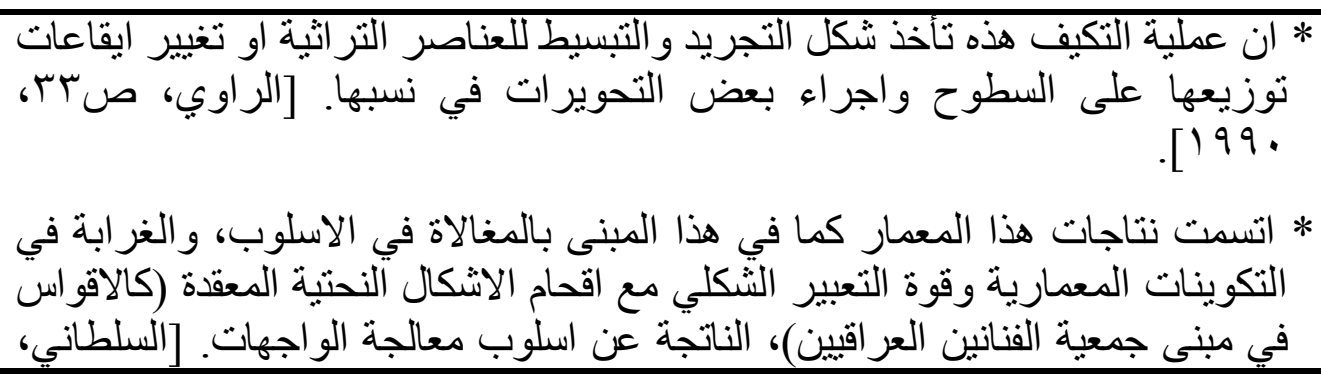 & X23 \\
\hline
\end{tabular}




\begin{tabular}{|c|c|}
\hline & \\
\hline * ان جديدة. [الر اوية صلتيف هذه تأخذ احيانا شكل التعبير عن العناصر التر اثية بمو اد مستحدة & X24 \\
\hline اختيار اشكال العقود. [الملا حويش، صبr & X25 \\
\hline يشروع مباني مجمع الجامعة المستنصيرية في بغاد للمعمار قحطان عوني عام & X3 \\
\hline 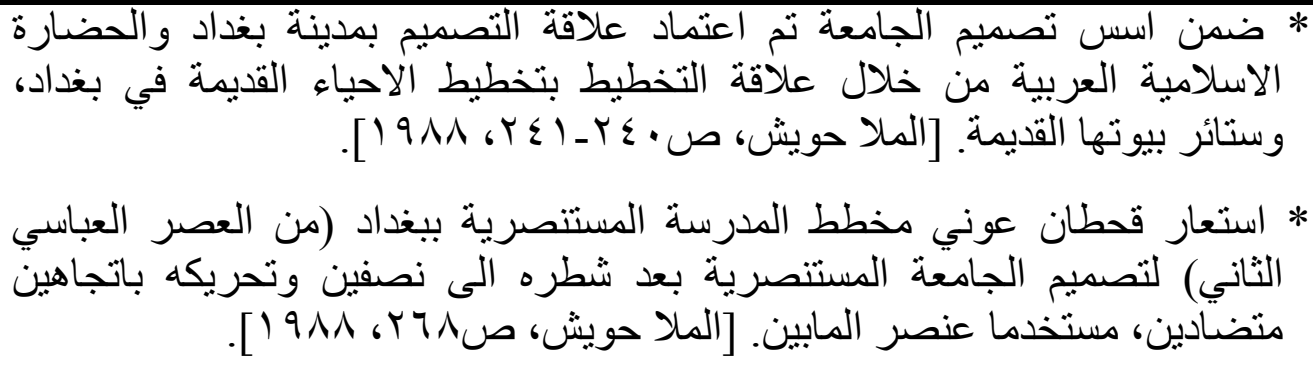 & X31 1 \\
\hline 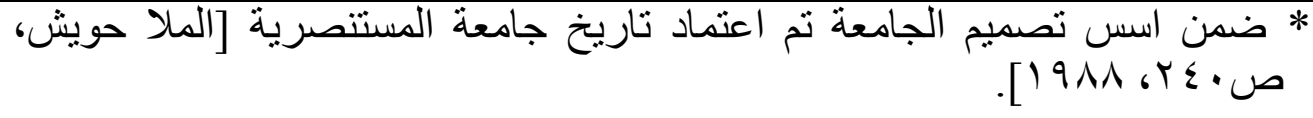 & X3 2 \\
\hline 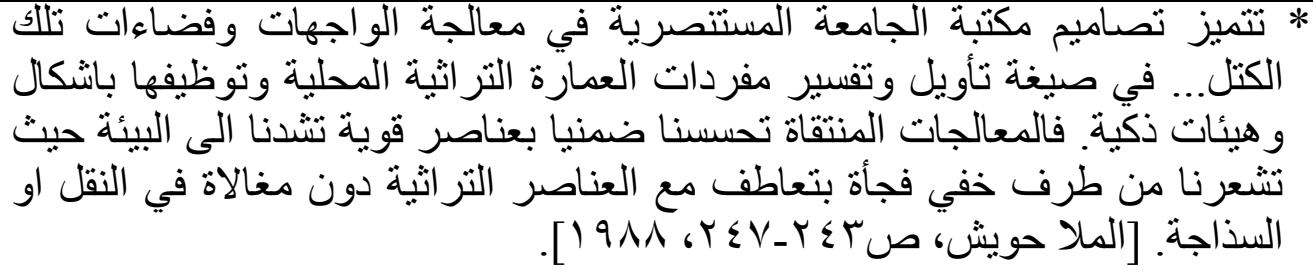 & X3 3 \\
\hline 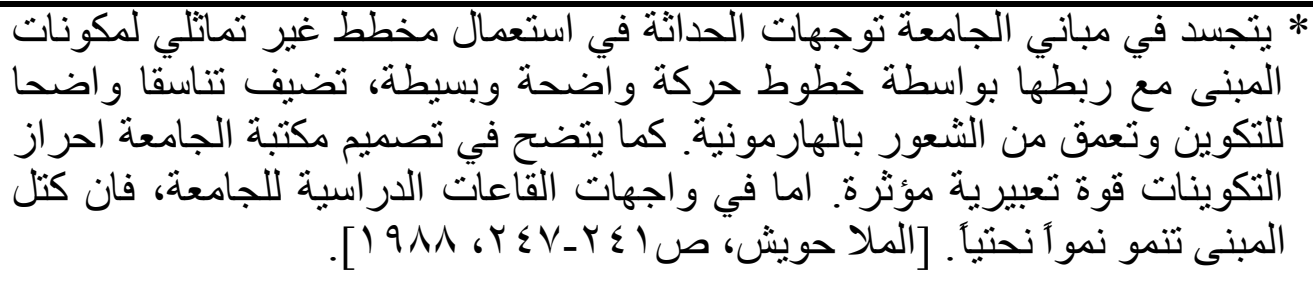 & X34 \\
\hline 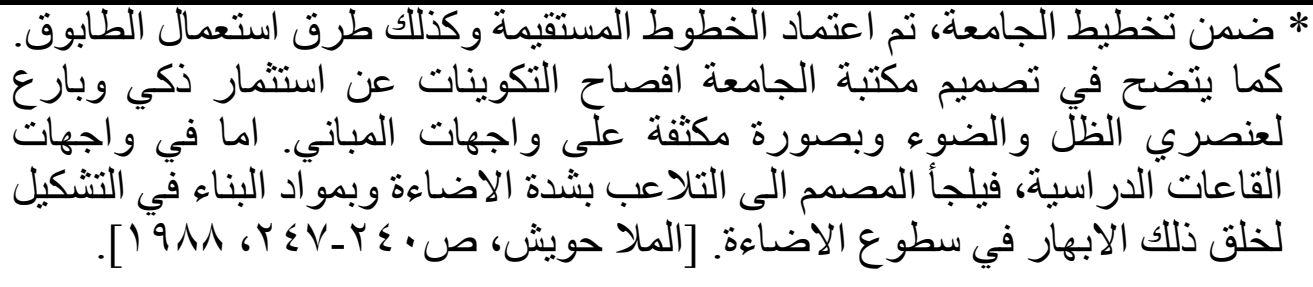 & X35 \\
\hline 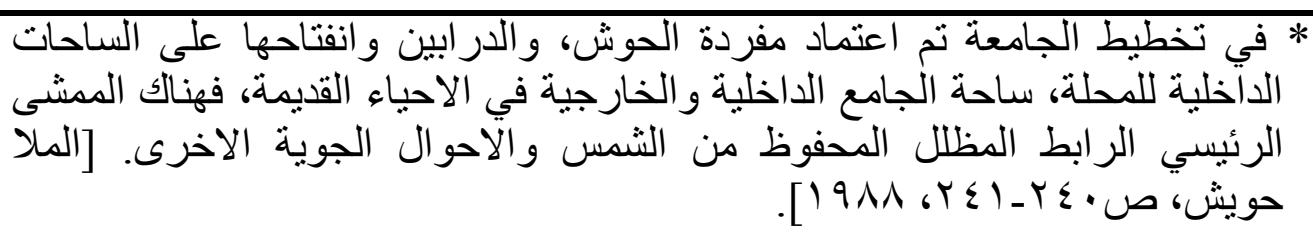 & X36 \\
\hline سار التبغ في بغد & 4 \\
\hline
\end{tabular}


* ظهرت في هذه العمارة تأثرات بجدارية لويس كان في مبنى ريشاردز للبحوث

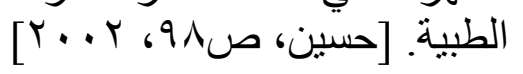

* احتوى هذا المبنى الكثير من العلاقات النحتية المتأثرة بنحتية القناطل و البروزات

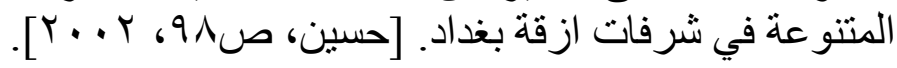
* ان هذا المبنى تأثر بمفردة الاكتاف نصف الدائرية المتأثرة بالجدار الثامخ لقصر

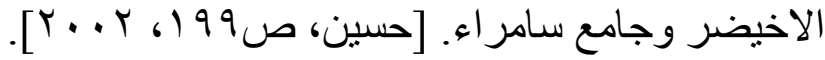

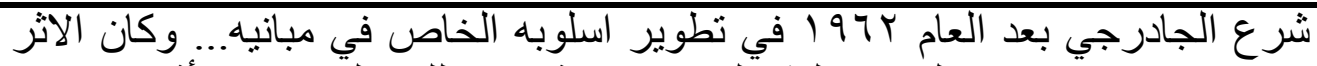

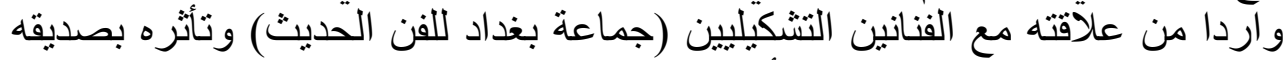

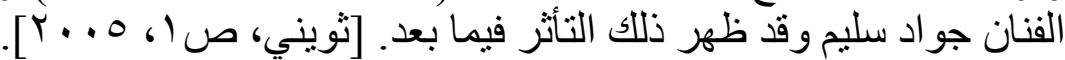

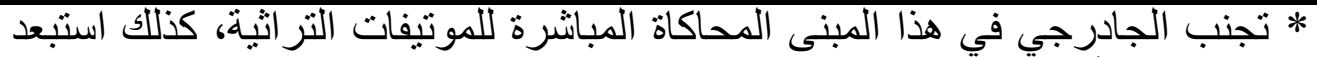
التقنيات المألوفة او الريفية لعدم توافقها مع اسماه بالصيغة الجمالية الميكانيكية. [1997,p. 578-579,Crutis]

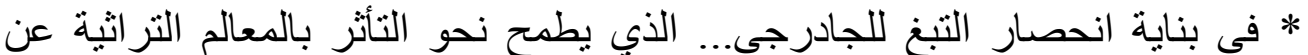

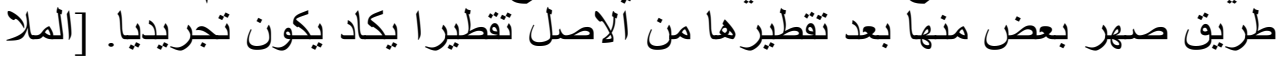

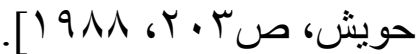

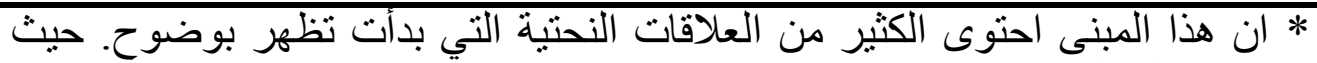

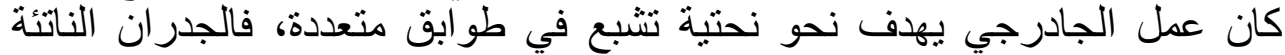

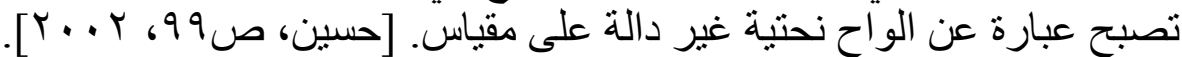

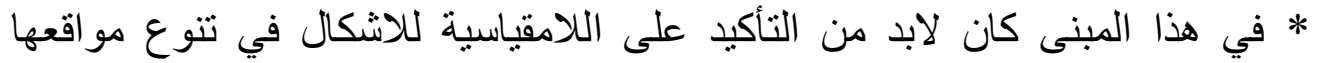

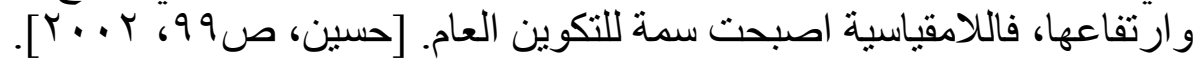
* ان التكرار كان في الطو ابق المتشابهة في عمارة انحصار التبغ. [حسين، ص99،،

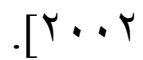

* ان اسلوب التعامل مع مفردة الاكتاف نصف الدائرية التي تبرز عن الجدار وتولد

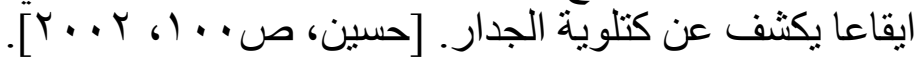

* في هذا المبنى الذي ... وينتمى الى قيم التراث من ناحية المعالجة التصميمية للقشرة

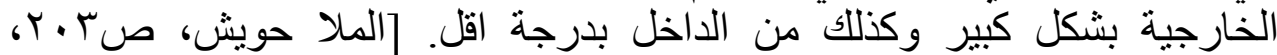
[1911

* في هذا المبنى، هنالك تعدد في صياغة الواجهات المذهلة بتضادها في المعالجات

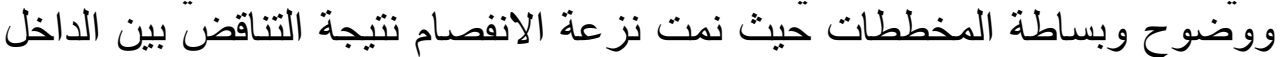

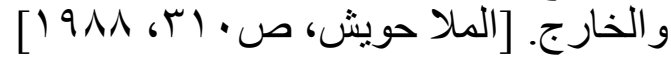

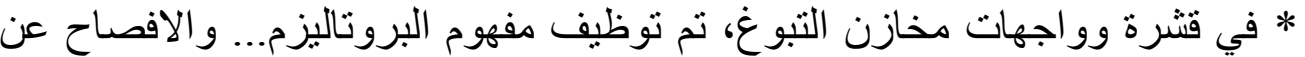

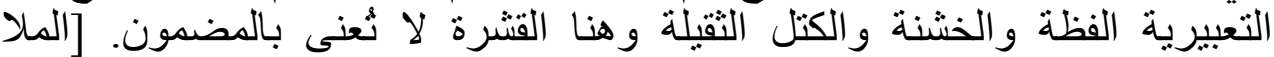

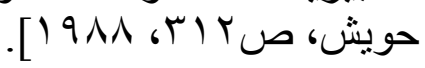

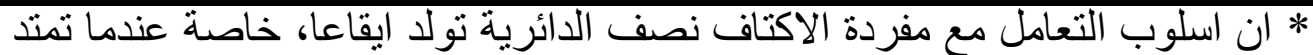

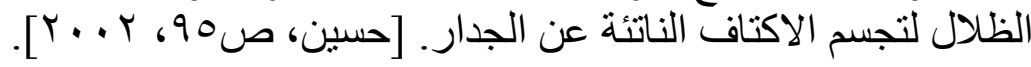


* شمارة الجادرجي الى التاكيد على القيم الاساسية التي تحسسها في التراث من خلال

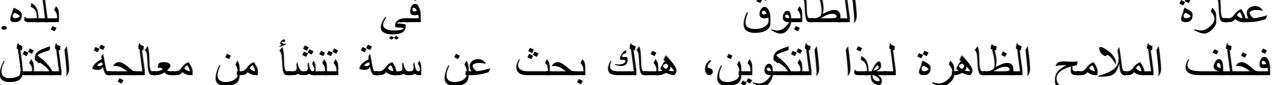

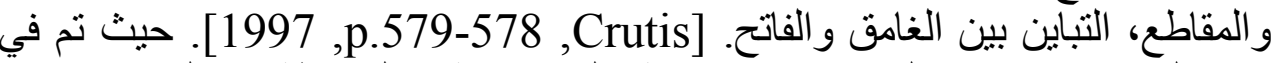

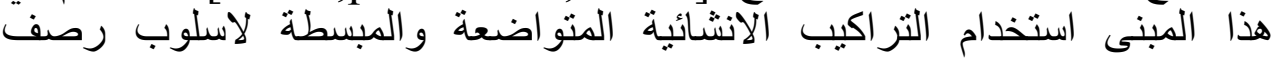

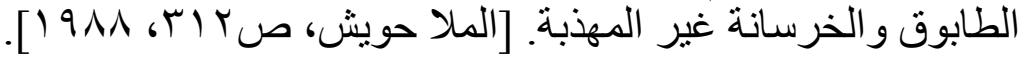
* في هذا المبنى تم التعامل مع مفردة الاكتاف نصف الدائرية. [الجادرجي، ص • . 1، .[1991 * الجدار الملتف ففي هذا المبنى نمت نزعة الانفصام تدريجيا نتيجة التناقض بين

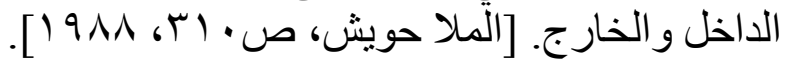

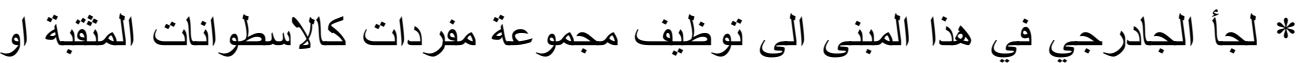

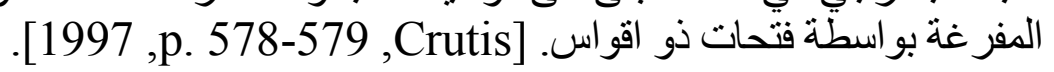
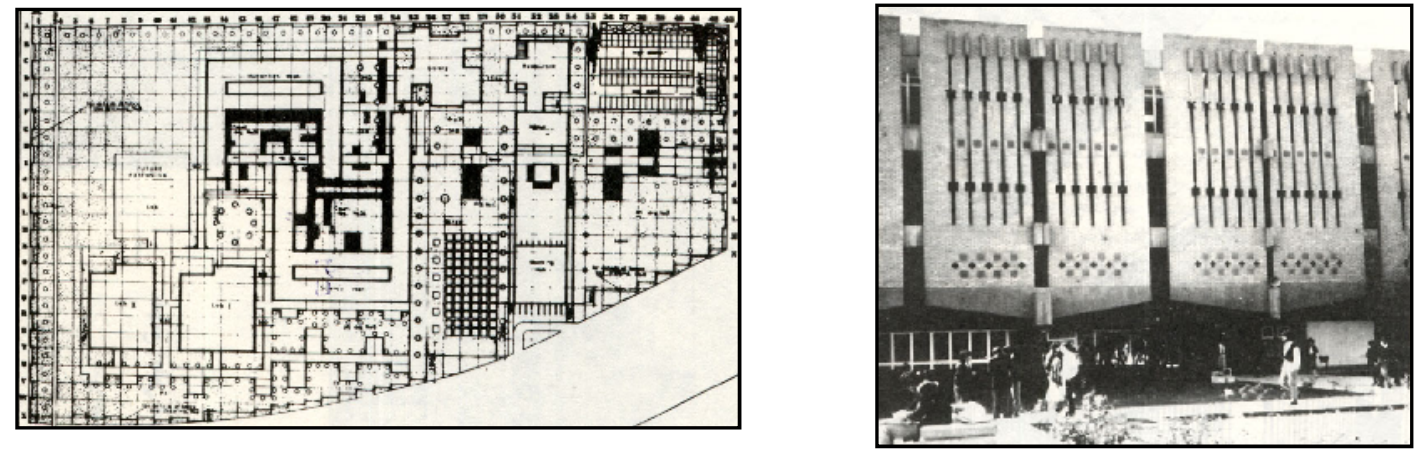

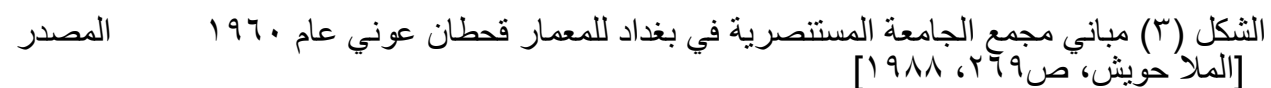




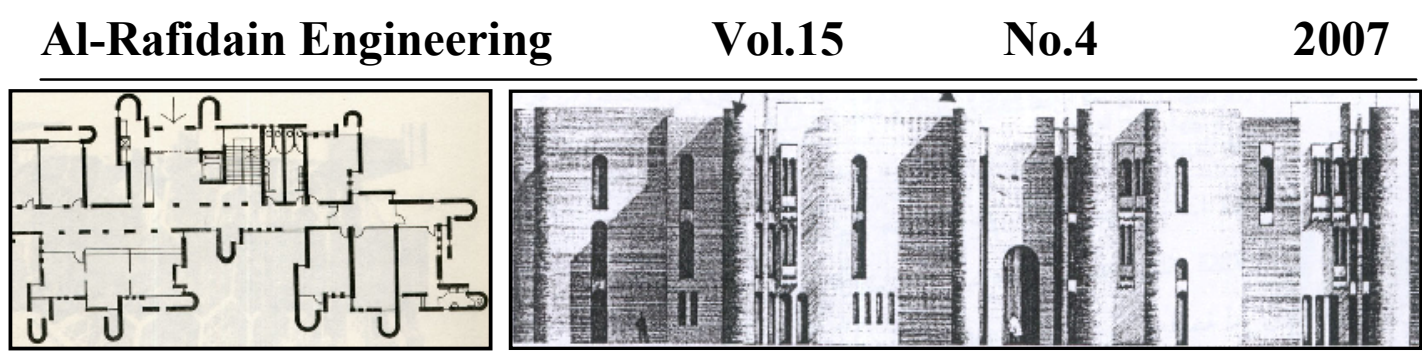

الثكل (ع) مشروع عمارة انحصار التبغ في بغداد للمعمار رفعت الجادرجي عام VT 19 ـ. المصدر

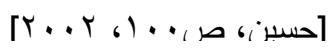

7- النتائج والاستنتاجات

1-7 مناقشة التتائج الخاصة بمتغير الاعتبار ات المعنوية الحضارية

أـ النتائج الخاصة بنوعية المراجع

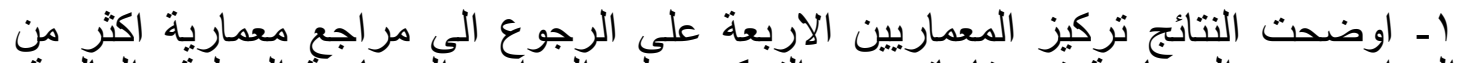

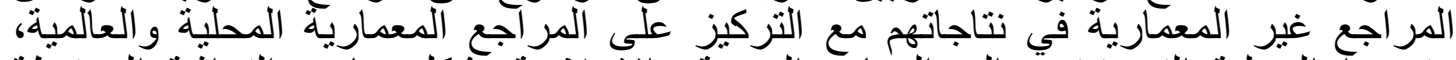

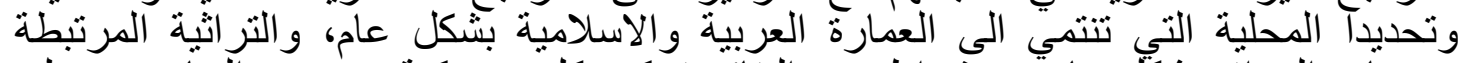

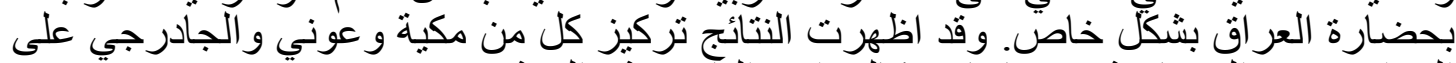

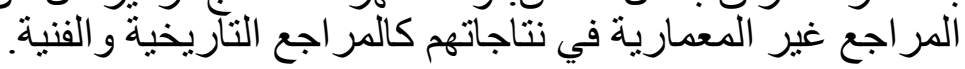

بـ النتائج الخاصة بنوعية او صيخ التعامل مع السياق المكاني

ا ـ اوضحت النتائج تعامل المعماريين الاربعة بوضوح مع مع السياق المكاني المرتبط بصيغ

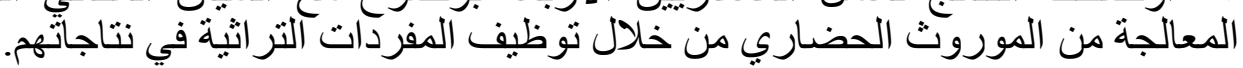

r- اوضحت النتائج توظيف د. مكية لصيغة الاستتساخ الاختز الي للمفردات التزراثية في نتاجاته بشكل مهزب

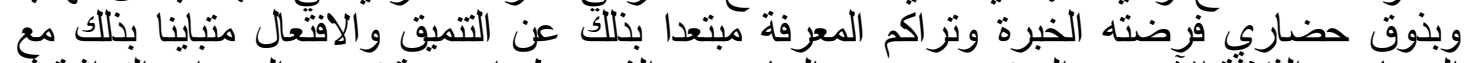

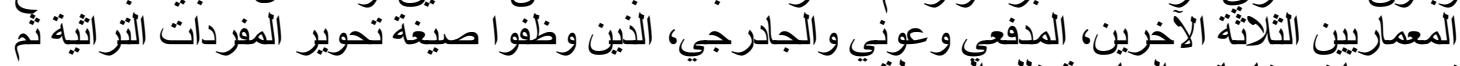

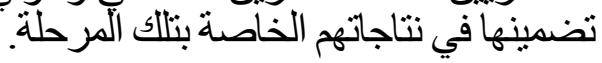

بـ اوضحت النتائج تباين المعماريين المدفعي و وعوني والجادرجي في مستوى التحوير . فقيما

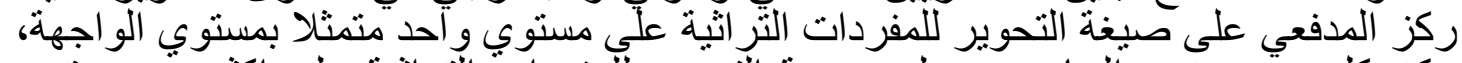

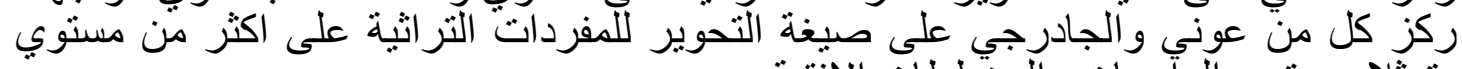

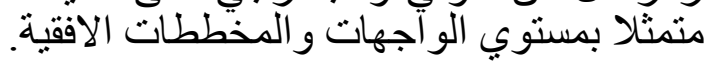

عـ اما من ناحية نوعية التحوير وصيغ تحققه في النتاجات المعمارية، فقد اظهرت النقات النتائج

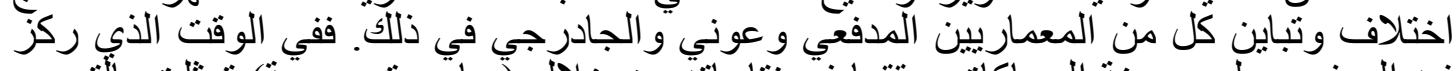

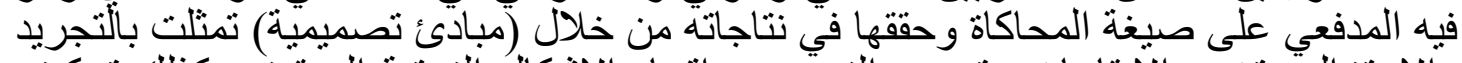

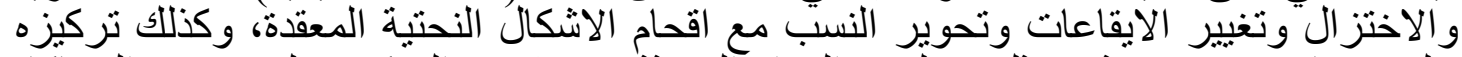

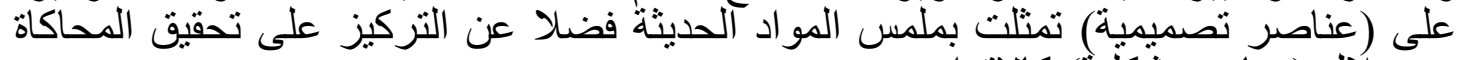
من خلال (عناصر شكلية) كالاقو اس. 
اما المعمار عوني فقد ركز على (التأيل) كصيغة من صيغ التحوير من خلال (مبادئ

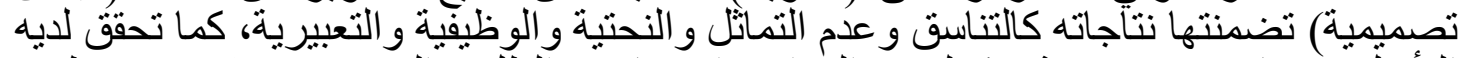

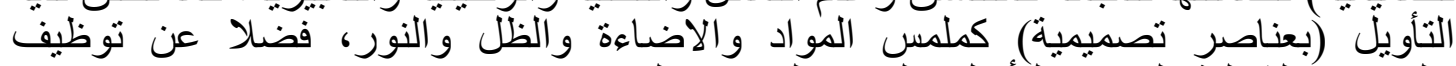

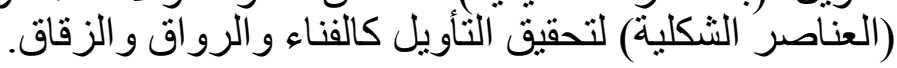

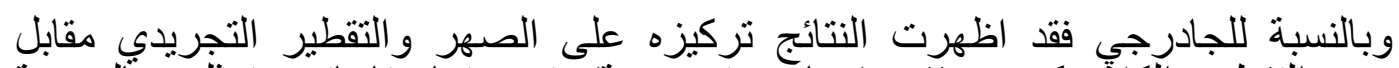

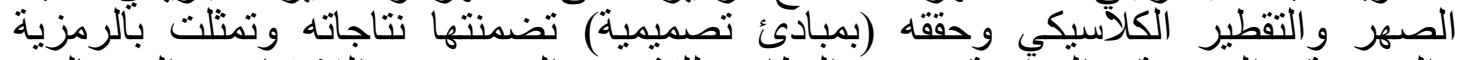

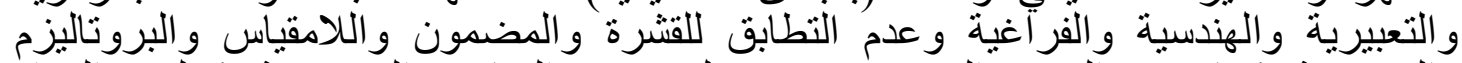

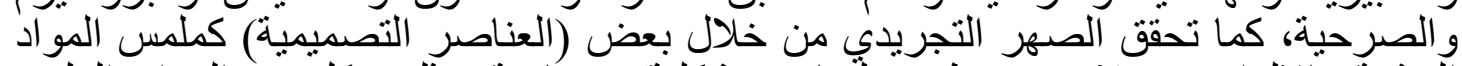

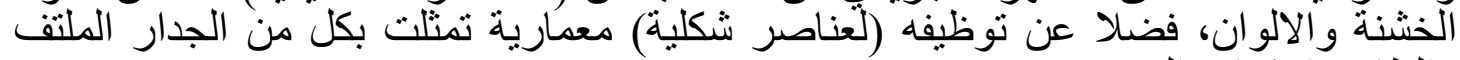
و الطاق و الاكتاف المستديرة.

2-7 الاستنتاجات النهائية الخاصة بعمارة المكان في العمارة العراقية المعاصرة (•9419(191. ركزت الاستتناجات النهائية على جانبين اساسيين تعلق الاول منهما بالاطار النظري، في حين ركز الجانب الثاني على الأستنتاجات الخاصة بآنتطبيق.

1 الاستتتاجات الخاصة بالاطار النظري:

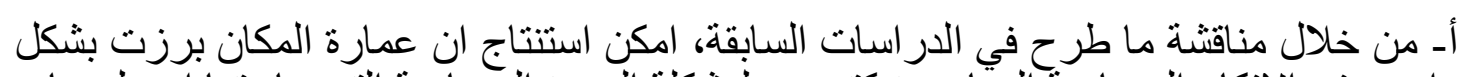

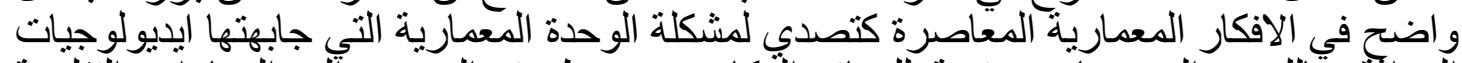

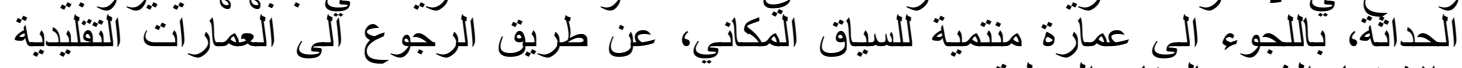
و الاهتمام الثديد بالبيئات المحلية.

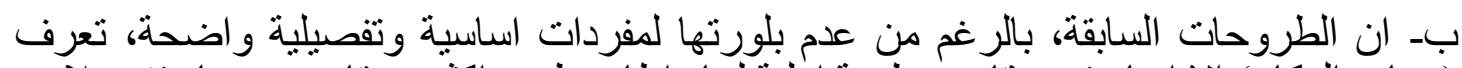

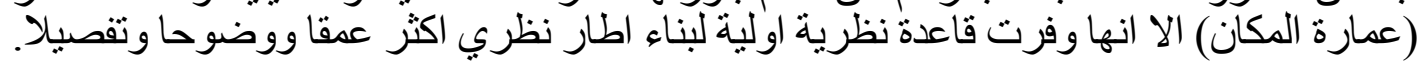

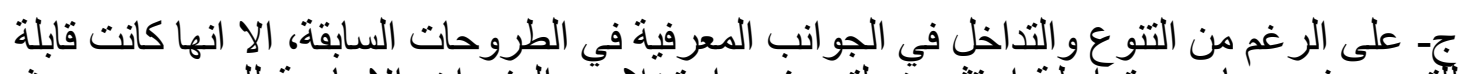

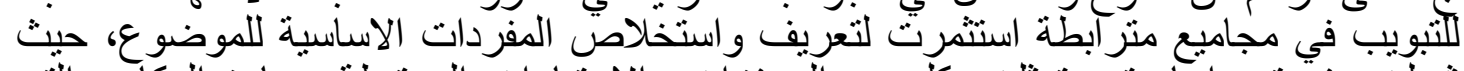

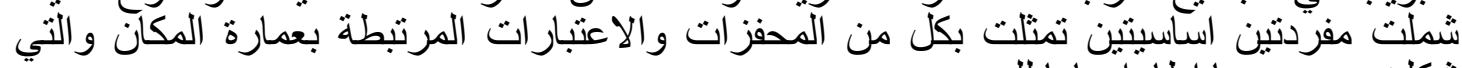

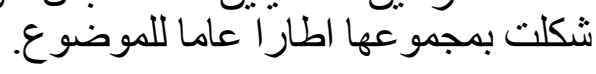

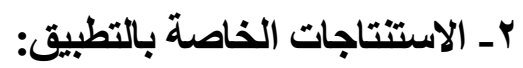

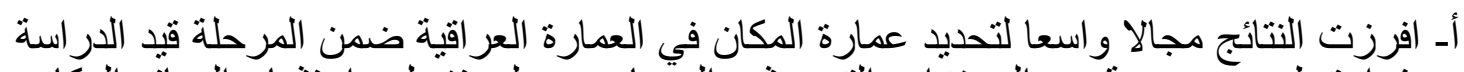

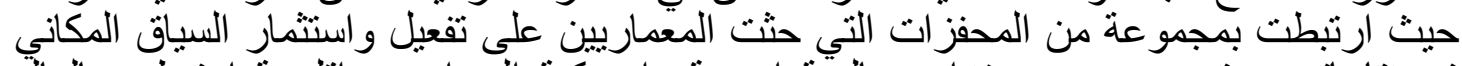

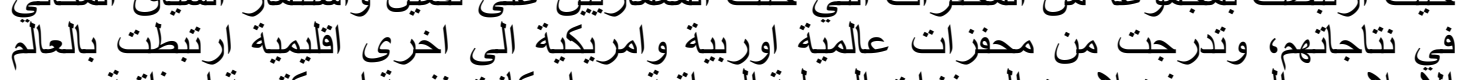
الآسلامي و العربي فضلا عن المحفز ات ات المحلية العربية اقية، سواء كانت نفعية او مكتسبة او ذانية. 


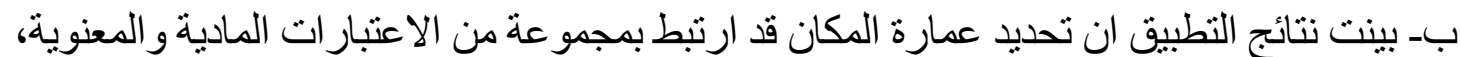

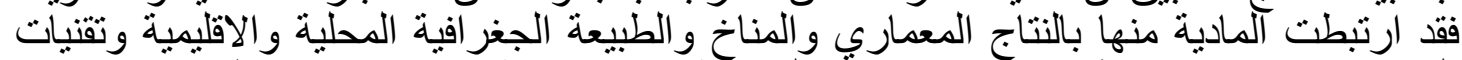

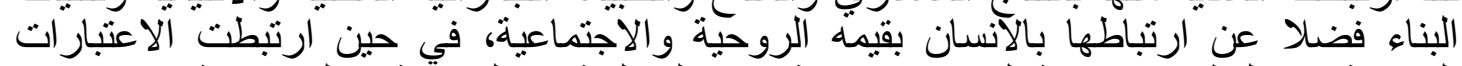

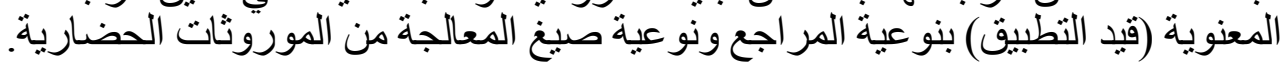

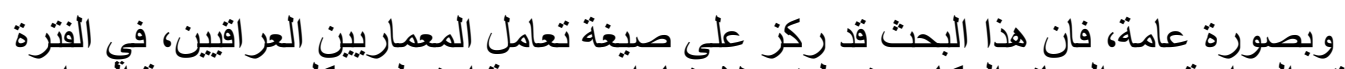

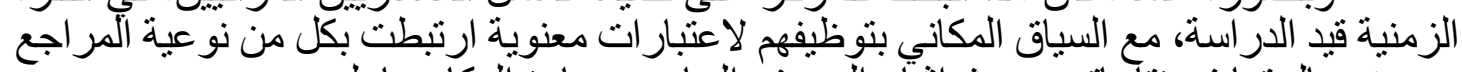

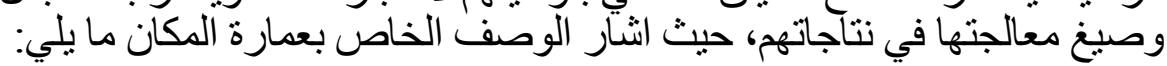

ا- برز حقل العمارة بشكل واضح كمرجع رئيسي لعمارة المكان واعمال المعماربين بالمقارنة مع العزي

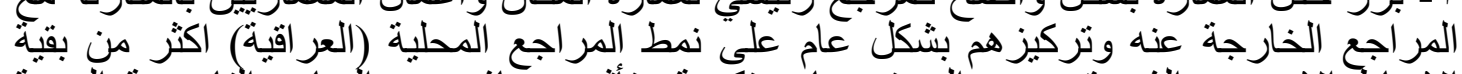

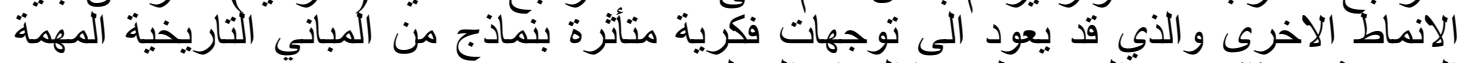

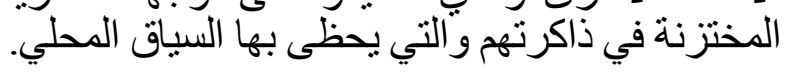

זـ ابرز المعماريون التعامل بوضوح مع الموروثات الحضارية اكثر من عدمه، وان هذا التعامل قد

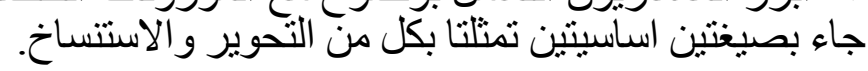

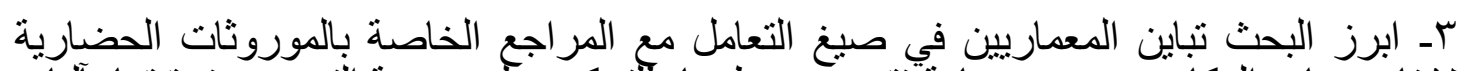

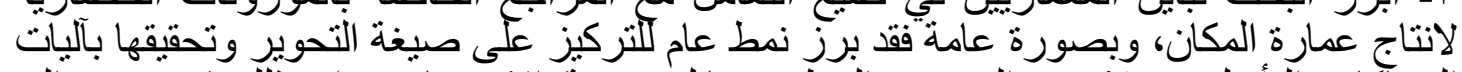

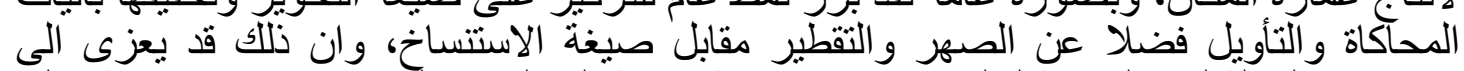

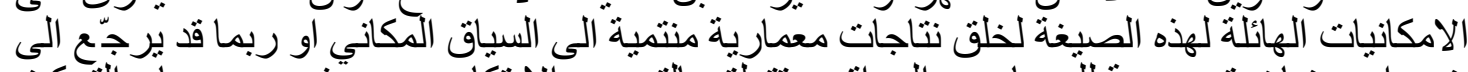

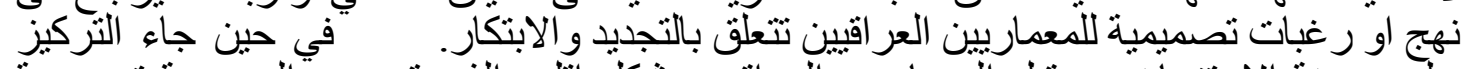

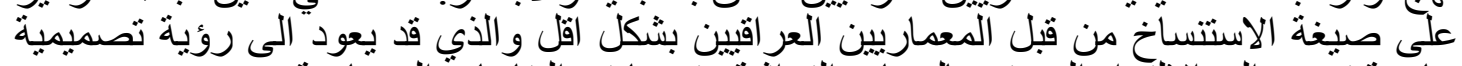

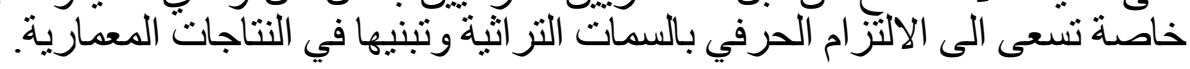

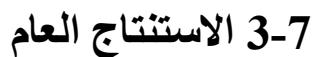

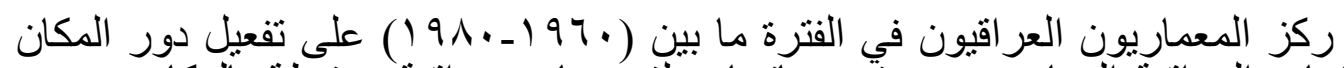

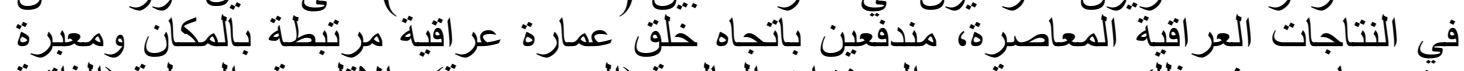

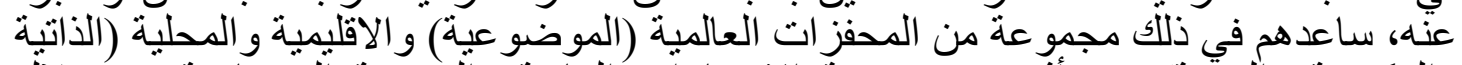

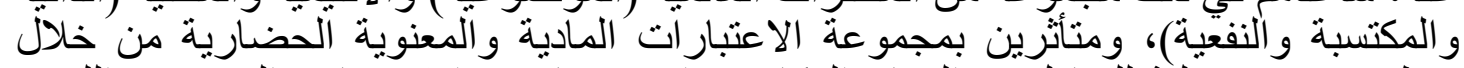

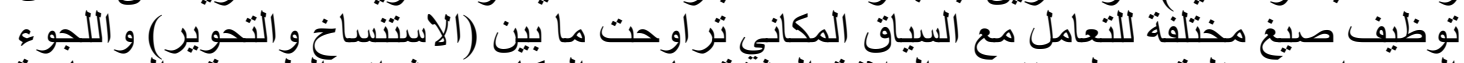

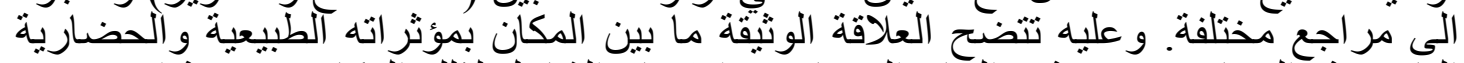

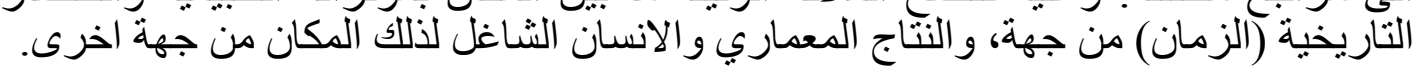

\section{4-7 التوصيات}

ا - يوصي البحث باستثمار ما تم التوصل اليه، فيما يتعلق بالقياس المطروح الخاص بمفردات

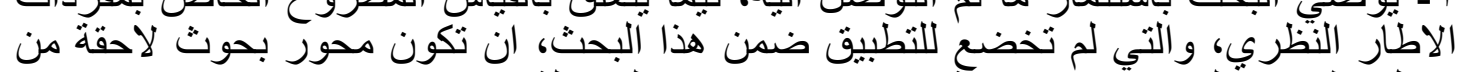

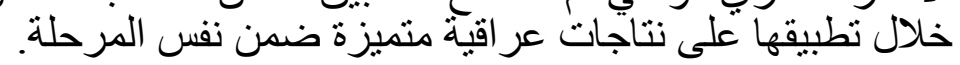

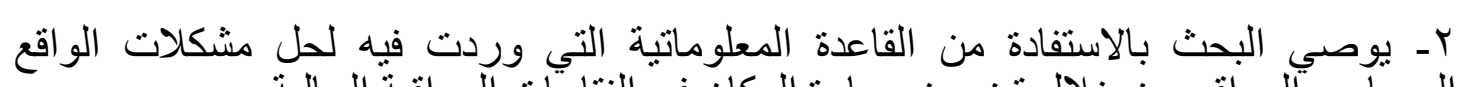

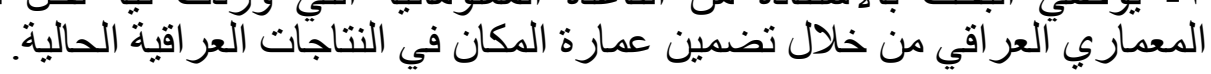




\section{المصادر}

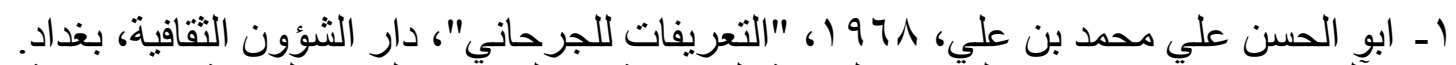

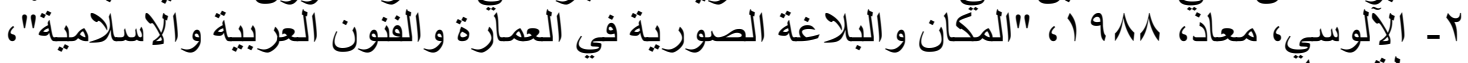

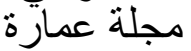

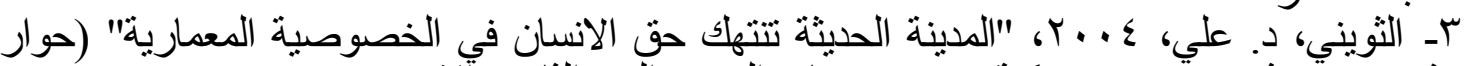

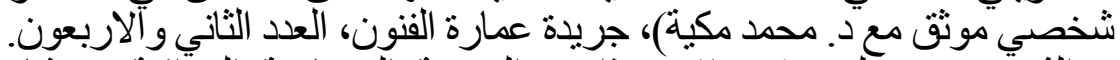

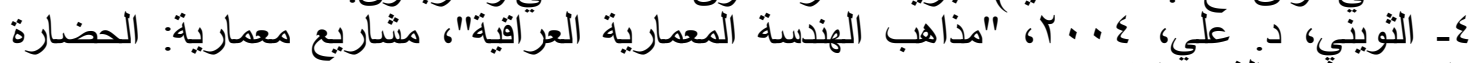

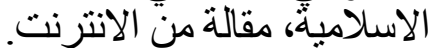

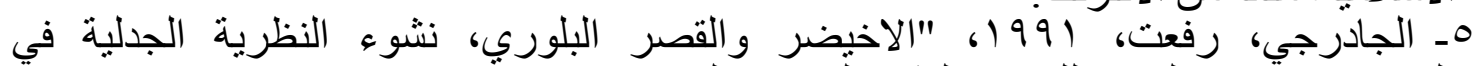

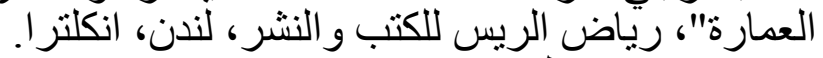

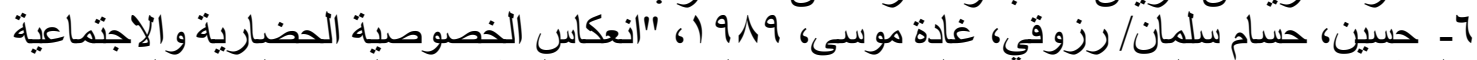

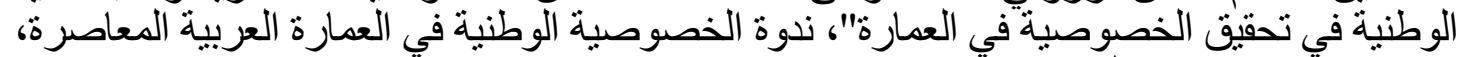

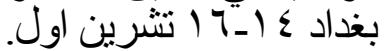

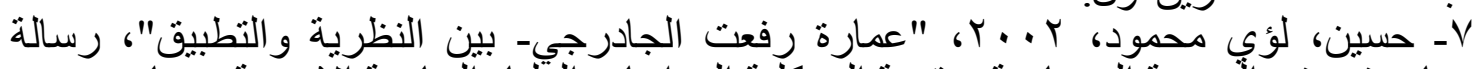

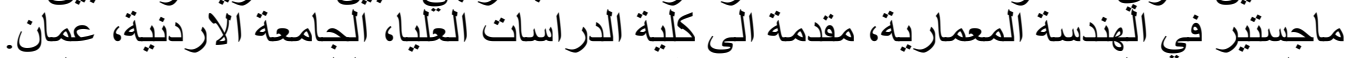

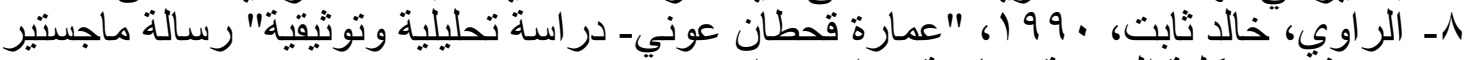

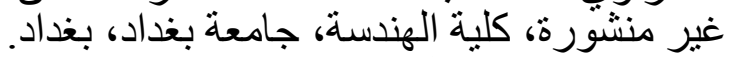

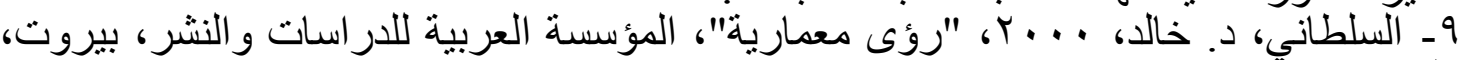

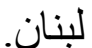

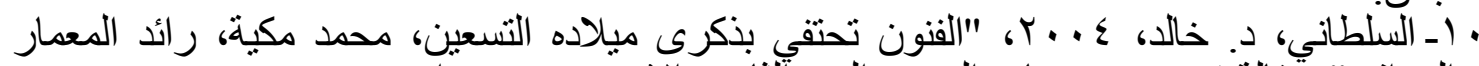

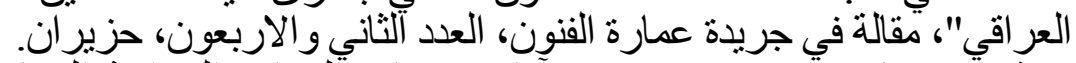

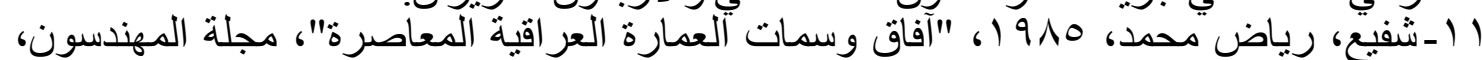

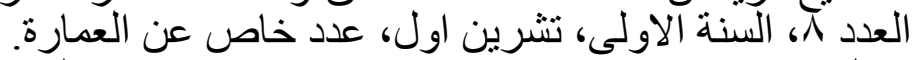

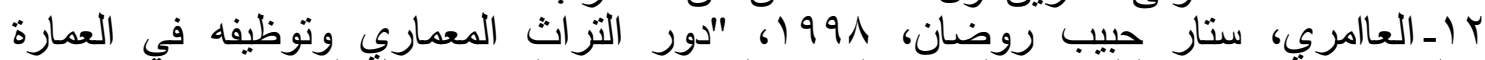

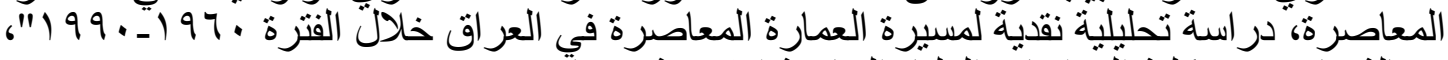

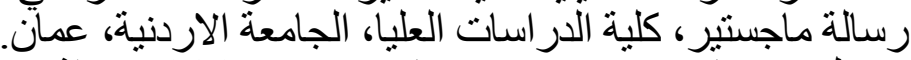

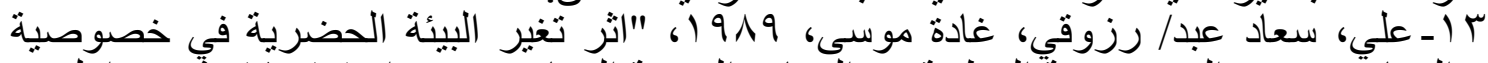

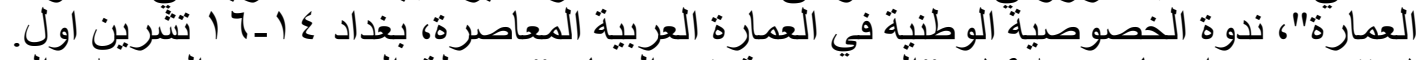

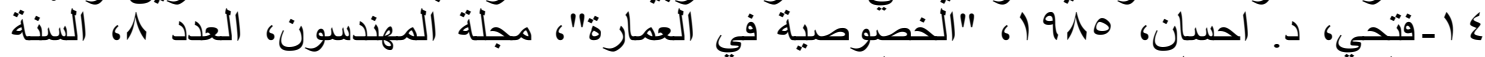

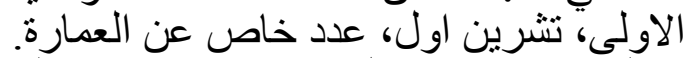

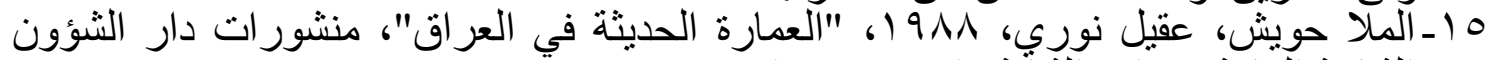

\section{References:}

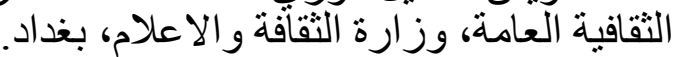

16-Bernard, Huef, 1984, "Regenerative Approach to Mosque Design", Mimar, No. 11, Agha Khan Award.

17-Casey, Edward, 1980, "Getting Placed", Spuing Publication, Ann Asbor, Mich.

18-Curtis, William J. R., 1997, "Modern Architecture Since 1900", $3^{\text {rd }}$ Edition, Phaidon Press Limited.

19- EL-Said, Essam, 1976, "Geometric Concepts to Islamic Art", World of Islamic Festival.

20-Green, H, 1976, "Mind and Image", Lexington, KY: The University of Kentucky Press.

21- Harris, Karsten, 1981, "Building and Terror of Time", Pespecta 19- The Yale, Mass.

22- Jencks, Charles, 1988, “Architecture Today”, London, Academy Edition. 


$$
\text { تم اجراء البحث في كلية الهنسسة - جامعة الموصل }
$$

